SMALL SHELLS FROM DREDGINGS OFF THE SOUTHEAST COAST OF THE UNITED STATES BY THE UNITED STATES FISHERIES STEAMER “ALBATROSS" IN 1885 AND 1886

\author{
By William H. Dall \\ Honorary Curator of Mollusks, United States National Museum
}

In 1885 the United States Fisheries steamer Albatross made a series of dredgings along the southeastern coast of the United States. One of the stations, No. 2415, was off the coast of Georgia in north latitude $30^{\circ} 44^{\prime}$, and west longitude $79^{\circ} 26^{\prime}$, with a depth of 440 fathoms (948 meters), in broken coral, coarse sand, and broken shell, bottom temperature $45.6^{\circ} \mathrm{F}$. $\left(7.5^{\circ} \mathrm{C}\right.$.).

The following year a similar dredging was made off Fernandina, Fla., at station 2668 , in north latitude $30^{\circ} 58^{\prime}$ and west longitude $79^{\circ} 38^{\prime}$, with a depth of 294 fathoms ( 678 meters) in gray sand and broken coral, bottom temperature $46.3^{\circ} \mathrm{F}$. $\left(8.2^{\circ} \mathrm{C}\right.$. $)$.

The material obtained was sifted, the larger shells taken out and the comparatively fine residue retained for its content of minute shells, foraminifera, etc. This residue was chiefly composed of fragments of the test of barnacles and echinoderms, the sand having been sifted out, and the fragments of coral, if any, removed; at all events none were found in it. Many of the contents had evidently been crushed or broken by the teeth of fishes. The pteropod remains had been derived from the surface, and very few of the other specimens had been alive when dredged. The total amount of material from off Georgia was somewhat more than a pint, and that from off Fernandina about twice as much.

Noticing that this contained many minute shells I took it home, put it on my desk, and from time to time as I had a few leisure moments, went over it, a teaspoonful at a time, and picked out the mollusks. Later when in quarantine at home on account of illness in the family, I separated these pickings and mounted the specimens for study, a work completed in 1898. Various duties compelled me to give little further attention to this material for some years. In 1920 the late John B. Henderson, jr., engaged on a monograph of the Dentalia of the southeast coast of the United States, utilized the

No. 2667.-Proceedings U. S. National Museum, Vol. 70, Art. I8 $24105-27 \dagger-1$ 
scaphopod material from this series. The references to this group in the following pages are taken from Bulletin 111 of the United States National Museum containing Mr. Henderson's excellent monograph, published in 1920 .

During the summer of 1922 I was able to take up the description of the other mollusca comprised in the present paper.

To avoid tiresome repetition the material from the two dredgings is referred to herein simply as "off Fernandina" and "off Georgia," since the localities are only a few miles apart and the difference in depth only 146 fathoms, the fauna may reasonably be regarded as nearly or quite the same for both places.

I have no means of determining what were all the larger species which were removed from these dredgings before they came into my hands, but I have found records of Aurinia gouldiana Dall, Drillia acrybia Dall, Pleurotoma dalli Verrill, and Triphora triserialis aspera Jeffreys; the last from off Georgia, the others from off Fernandina.

I have omitted from the list surface forms like the Pteropods and Williamia, also two or three shells which are clearly adventitious.

My colleague Dr. Paul Bartsch, has kindly determined and described the Pyramidellidae of the collection, a group to which he has paid particular attention.

The total number of species in the material examined is 337 . This includes 5 species of Brachiopoda, 41 Pelecypoda, 14 Scaphopoda, and 277 Gastropoda. ${ }^{1}$ Of these 73 species were found at both stations, 171 only off Fernandina, and 84 only off Georgia. The difference may partly be due to the fact that the total amount of bottom material from off Georgia was only about half as much as that collected off Fernandina.

Out of the total number (337) of species collected, 204 appear to be undescribed, which gives an idea of the richness of certain localities on the sea bottom when conditions are favorable. If we add to this number 6 species of Scaphopods described by Mr. Henderson the total is still more striking.

\section{LIST OF THE SPECIES}

BRACHIOPODA

Terebratulina cailleti Crosse.

Gryphus cubensis Pourtalés.

Gryphus affinis Calcara.

Dallina floridana Pourtalés.

Pelagodiscus atlanticus King.

MOLLUSCA--PELECYPODA

Nucula culebrensis E. A. Smith. Nucula fernandina Dall.

Nucula verrillii Dall.

Nucula proxima ovata Verrill.
Leda messanensis Seguenza.

Leda orixa Dall.

Leda aspecta Dall.

Leda bipennis Dall.

${ }^{1}$ These numbers refer to the species in the present paper. See for additions the Supplement on p. 115. 
Yoldiella pygmaea Münster

Yoldiella fraterna Verrill and Bush.

Malletia (Neilo) dilatata Philippi.

Tindaria cytherea Dall.

Tindaria acinula Dall.

Pseudoglomus pompholyx Dall.

Pristigloma nitens Jeffreys.

Limopsis tenella Jeffreys.

Limopsis minuta Philippi.

Limopsis radialis Dall.

Limopsis onchodes Dall.

Cucullaria sagrinata Dall.

Barbatia, species.

Bathyarca orbiculata Dall.

Bathyarca inaequalis Dall.

Pseudamusium nanum Verrill and Bush.

Propeamusium pourtalesianum Dall.
Limatula laminifera E. A. Smith.

Limaea bronniana Dall.

Poromya granulata Nyst and Westendorp.

Lyonsiella abyssicola Sars.

Verticordia seguenzae Dall.

Verticordia ornata Orbigny.

Montacuta limpida Dall.

Erycina fernandina Dall.

Thyasira succisa Jeffreys.

Kelliella nitida Verrill.

Cuspidaria arctica Sars.

Cuspidaria, species.

Halonympha claviculata Dall.

Astarte globula Dall.

Ervilia concentrica Gould.

Diplothyra smithii Tryon.
Dentalium ceratum Dall

Dentalium tubulatum Henderson

Dentalium ensiculus Jeffreys

Dentalium pressum Pilsbry and Sharp

Dentalium ophiodon Dall

Siphonodentalium platamodes Watson.

Siphonodentalium striatinum Henderson
Cadulus providensis Henderson.

Cadulus rastridens Watson.

Cadulus regularis Henderson.

Cadulus acus Dall.

Cadulus transitorius Henderson.

Cadulus obesus Watson.

Cadulus platensis Henderson
Acteon danaida Dall.

Acteon incisus Dall.

Acteon hebes Verrill.

Acteon semicingulatus Dall.

Acteon particolor Dall.

Acteon juvenis Dall.

Acteon liostracoides Dall.

Acteon propius Dall.

Acteon parallelus Dall.

Acteon lacunatus Dall.

Ringicula nitida Verrill.

Ovulactaeon meeki Dall.

Volvulella mörchi Dall.

Retusa recta Orbigny:

Cylichna verrillii Dall.

Pyrunculus floridensis Dall.

Pyrunculus rushi Dall.

Pyrunculus medius Dall.

Pyrunculus curtulus Dall.

Bullaria indolens Dall.

Leucophysema eburneola Dall.

Leucophysema abyssicola Dall.

Sabatia bathymophila Dall.

Scaphander stigmatica Dall.

Diaphana floridana Dall.

Philine lucida Dall.
MOLLUSCA-GASTROPODA

Daphnella hyperlissa Dall.

Gymnobela imitator Dall.

Gymnobela illicita Dall.

Gymnobela lanceata Dall.

Gymnobela grundifera Dall.

Mangilia ipara Dall.

Mangilia sericifila Dall.

Mangilia, var. strongyla Dall.

Pleurotomella stearina Dall.

Pleurotomella corrida Dall.

Eucyclotoma aperta Dall.

Eubela limacina Dall.

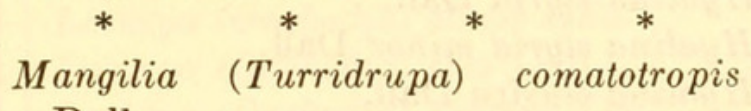

Dall.

* $\quad *$ * $\quad * \quad * \quad *$

$\underset{*}{\text { Pleurotomella }} \underset{*}{\text { lineola Dall. }}$ *

Mangilia ischna Dall.

Pleurotomella vaginata Dall.

* *

Mangilia acrocarinata Dall.

$* \quad * \quad *$

Philbertia perdecorata Dall.

Philbertia perdecorata, var. lionta Dall.

Philbertia extenuata Dall. 
Clathrodrillia inimica Dall.

Clathrodrillia orellana Dall.

Clathrodrillia dolana Dall.

Clathrodrillia fanoa Dall.

Clathrodrillia acrybia Dall.

Suavodrillia? textilia Dall.

Daphnella sagena Dall.

Daphnella epomis Dall.

Mangilia dalli Verrill.

Mangilia chasmata Dall.

Mangilia lastica Dall.

Mangilia tachnodes Dall.

Mangilia crossata Dall.

Mangilia cryera Dall.

Mangilia christina Dall.

Mangilia fritillaria Dall.

Mangilia subcircularis Dall.

Mangilia percompacta Dall.

Mangilia acloneta Dall.

Mangilia acloneta, var. cestrota Dall.

Mangilia cratera Dall.

Mangilia areia Dall.

Mangilia loraeformis Dall.

Mangilia pelagia Dall.

Mangilia rhabdea Dall.

Cymatosyrinx ebur Dall.

Admete microscopica Dall.

Admete nodosa Verrill and Smith.

Olivella tubulata Dall.

Olivella bullula Reeve.

Marginella fernandinae Dall.

Marginella canilla Dall.

Marginella ocella Dall.

Marginella tanora Dall.

Marginella incessa Dall.

Marginella inepta Dall.

Marginella imitator Dall.

Marginella microgonia Dall.

Marginella esther Dall.

Hyalina styria Dall.

Hyalina styria minor Dall.

Hyalina elusiva Dall.

Hyalina avenella Dall.

Cypraeolina hadria Dall.

Cypraeolina tinolia Dall.

Cypraeolina truncata Dall.

Aurinia gouldiana Dall.

Mitra styliola Dall.

Mitra zilpha Dall.

Mitra hendersoni Dall.

Mitra grammatula Dall.

Mitra wandoënsis Holmes.

Mitromorpha biplicata Dall.

Mitromorpha undulata Dall.
Fasciolaria, species.

Fusinus schrammi Crosse.

Fusinus bullatus Dall.

Fusinus vitreus Dall.

Siphonorbis perminutus Dall.

Astyris pura Verrill.

Astyris perlucida Dall.

Astyris stemma Dall.

Astyris (Fluella) vidua Dall.

Astyris (Fluella) amphissella Dall.

Astyris (Fluella) rushii Dall.

Astyris (Fluella) enida Dall.

Astyris (Fluella) appressa Dall.

Astyris (Plectaria) crumena Dall.

Astyris (Plectaria) embusa Dall.

Astyris (Plectaria) euribia Dall.

Astyris (Plectaria) projecta Dall.

Astyris (Plectaria) albella C. B. Adams.

Astyris (Plectaria), species.

Astyris (Parasagena) georgiana Dall.

Astyris (Parasagena) sagenata Dall.

Columbella (Atilia ?) mystica Dall.

Pteropurpura tristicha Dall.

? Urosalpinx verrillii Dall.

?Urosalpinx stimpsoni Dall.

Coralliophila lactuca Dall.

Epitonium marcoënse Dall.

Epitonium fractum Dall.

Epitonium azelotes Dall.

Epitonium opalinum Dall.

Epitonium lavaratum Dall.

Epitonium discobolaria Dall.

Epitonium caninum Dall.

Epitonium, species.

Opalia, species.

Opalia? dromio Dall.

Melanella callistemma Dall.

Melanella oleacea Kurtz and Stimpson.

Melanella conoidea Kurtz and Stimpson.

Melanella penna Dall.

Melanella rectiuscula Dall.

Melanella fernandinae Dall.

Melanella cinca Dall.

Melanella abida Dall.

Melanella corrida Dall.

Melanella arcuata C. B. Adams.

Melanella ophiodon Dall.

Melanella anachorea Dall.

Melanella stamina Dall.

Melanella patula Dall and Simpson.

Melanella versa Dall.

Melanella ira Dall.

Melanella parallela Dall.

Strombiformis elata Dall. 
Strombiformis fusus Dall.

Niso microforis Dall.

Aclis georgiana Dall.

Aclis dalli Bartsch.

Aclis limata Dall.

Aclis stilifer Dall.

Aclis fernandinae Dall.

Aclis pendata Dall.

Aclis conula Dall.

Aclis lata Dall.

Aclis pyramida Dall.

Aclis tenuis Verrill.

Aclis cubana Bartsch.

Aclis rhyssa Dall.

Aclis hendersoni Dall.

Aclis (Amblyspira) immaculata Dall.

Mucronalia mammillata Dall.

Mucronalia suava Dall.

Mucronalia? bulimuloides Dall.

Stilifer verrilli Dall.

Stilifer minima Dall.

Stilifer minuta Dall.

Pyramidella (Longchaeus), species.

Pyramidella (Sulcorinella) camara Bartsch.

Pyramidella (Syrnola) fernandina Bartsch.

Pyramidella (Syrnola) floridana Bartsch.

Pyramidella (Syrnola) georgiana Bartsch.

Turbonilla (Ptycheulimella) hespera

Bartsch.

Turbonilla

Bartsch.

Turbonilla

Bartsch.

Turbonilla

Bartsch.

Turbonilla

Bartsch.

Turbonilla

Bartsch.

Turbonilla

Bartsch.

Turbonilla

Bartsch.

Turbonilla (Strioturbonilla) leta Bartsch.

Turbonilla (Strioturbonilla) myia

Bartsch.

Turbonilla

Bartsch.

Turbonilla

Bartsch.
Turbonilla (Strioturbonilla) nonica

Bartsch.

Turbonilla (Pyrgiscus) conoma Bartsch.

Turbonilla (Pyrgiscus) miona Bartsch.

Turbonilla (Mormula) anira Bartsch.

Odostomia (Evalea) fernandina Bartsch.

Odostomia (Evalea) ryclea Bartsch.

Odostomia (Evalea) ryalea Bartsch.

Pedicularia decussata Gould.

Seguenzia florida Dall.

Seguenzia rushi Dall.

Alabina cerithidioides Dall.

Mathilda georgiana Dall.

Mathilda yucatecana Dall.

Mathilda lacteosa Dall.

Mathilda globulifera Dall.

Mathilda granifera Dall.

Mathilda amaea Dall.

Mathilda rushii Dall.

Mathilda hendersoni Dall.

Tuba jeffreysi Dall.

Turritellopsis floridana Dall.

Triphora (Biforina) carraca Dall.

Triphora (Biforina) georgiana Dall.

Triphora (Biforina) indigena Dall.

Triphora (Biforina) aspera Jeffreys.

Triphora (Strobiligera) pompona Dall.

Triphora (Strobiligera) gaesona Dall.

Triphora (Strobiligera) enopla Dall.

Triphora (Strobiligera) meteora Dall.

Triphora (Strobiligera) compsa Dall.

Triphora (Strobiligera) sentoma Dall.

Cerithiopsis georgiana Dall.

Laskeya (Onchodia) benthica Dall.

Laskeya (Onchodia) merida Dall.

Laskeya (Onchodia) serina Dall.

Laskeya (Onchodia) docata Dall.

Laskeya (Onchodia) argentea Dall.

Laskeya (Onchodia) decora Dall.

Laskeya (Onchodia) althea Dall.

Laskeya (Onchodia) elima Dall.

Laskeya (Onchodia) elsa Dall.

Laskeya (Onchodia) apicina Dall.

Laskeya (Onchodia) honora Dall.

Laskeya (Onchodia) eliza Dall.

Laskeya (Onchodia) petala Dall.

Laskeya (Onchodia) leipha Dall.

Stilus vitreus Dall.

Cerithiella producta Dall.

Seila subalbida Dall.

Trichotropis (Iphinopsis) nuda Dall.

Trichotropis (Iphinopsis) turrita Dall.

Rissoina mayori Dall. 
Rissoa pompholyx Dall.

Rissoa (Nodulus) fernandinae Dall.

Rissoa (Cingulina) curta Dall.

Capulus intortus Lamarck.

Polinices (Euspira) bahamensis Dall.

Leptothyra induta Watson.

Solariella cancilla Dall.

Solariella aegleis Watson.

Solariella crossata Dall.

Euchelus eucasta Dall.

Basilissa (Ancistrobasis) costulata Watson.

Basilissa watsoni Dall.

Vitrinella georgiana Dall.

Cocculina lissocona Dall.

Diadora bermudensis Dall and Bartsch.
Puncturella profundi Jeffreys.

Puncturella profundi multifila Dall.

Puncturella oxia Watson.

Puncturella hendersoni Dall.

Puncturella circularis Dall.

Puncturella tenuicula Dall.

Puncturella (Cranopsis) asturiana

Fischer.

Fissurisepta triangulata Dall.

Emarginula (Rimula) larva Dall.

Emarginula cancellata Philippi.

Emarginula compressa Cantraine.

Scissurella crispata Fleming.

Scissurella proxima Dall.

Bathysciadium? concentricum Dall.

Ischnochiton striolatus Gray.

\section{BRACHIOPODA}

\section{Family TEREBRATULIDAE}

\section{Genus TEREBRATULINA Orbigny}

\section{TEREbRatulina CaIlleti Crosse}

Terebratulina cailleti Crosse, Journ. de Conchyl., vol. 13, p. 27, figs. 1, 2, 3, 1865.-Dall, Bull. Mus. Comp. Zoöl., vol. 3, No. 1, p. 10, 1871.Davidson, Mon. Rec. Brach., pt. 1, p. 26, pl. 5, figs. 41, 42, 1886.-Dall, Annot. List Rec. Brach. Nat. Mus., p. 308, 1920.

Off Georgia and Fernandina to Barbados, in 18 to 450 fathoms, the tropical specimens in the shallower water.

\section{Genus GRYPHUS Megerle \\ GRYPHUS CUBENSIS Pourtalés}

-Terebratula cubensis Pourtalés, Bull. Mus. Comp. Zoöl., vol. 1, No. 6, p. 109, Dec. 1867.-Dall, Bull. Mus. Comp. Zoöl., vol. 3, p. 3, pl. 1, figs.

2, 8-15, 1871.-Davidson, Challenger Brach., p. 28, pl. 2, figs. 10, 11, 1880.

Gryphus cubensis Dald, Annot. List Rec. Brach. Nat. Mus., p. 315, 1920.

Off Fernandina and to the Gulf of Mexico and south to the Lesser Antilles in 75 to 400 fathoms, living.

\section{GRYPHUS AFFINIS Calcara}

Terebratula affinis Calcara, Cenno Moll. viv. e foss. di Sicilia, p. 48, 1845. Gryphus affinis DALL, Annot. List Brach., Proc. U. S. Nat. Mus. No. 2314, p. 312,1920 .

Off Georgia and Fernandina, four valves tentatively referred to this species, which was described from the Mediterranean. 


\section{Family TEREBRATULIDAE}

\section{Genus DALLINA Beecher}

DALLina Floridana Pourtalés

Waldheimia floridana Pourtalés, Bull. Mus. Comp. Zoöl., vol. 1, p. 127, 1868.-Dall, Bull. Mus. Comp. Zoöl., vol. 3, p. 12, pl. 1, fig. 3; pl. 2, figs. 1, 2, 3, 1871.-Davidson, Mon. Rec. Brach., pt. 2, p. 59, pl. 12, figs. $1-5,1887$.

Dallina floridana Beecher, Trans. Conn. Acad. Sci., vol. 9, p. 382, pl. 1, fig. 45, 1893.-DAll, Annot. List Rec. Brach. Nat. Mus., p. 358, 1920.

Off Fernandina and in the Gulf of Mexico and southward to Porto Rico, in 90 to 270 fathoms.

\section{Family DISCINIDAE}

\section{Genus PELAGODISCUS Dall \\ PELAGOdiscus atlanticus King}

Discina atlantica KING, Proc. Nat. Hist., Soc. Dublin, vol. 5, pp. 170-173, 1868.-Jeffreys, Ann. Mag. Nat. Hist., ser. 4, vol. 18, p. 252, 1856.Davidson, Challenger Brach, p. 62, pl. 4, figs. 17-18, 1880.

Discinisca atlantica Dall. Proc. Acad. Nat. Sci. Phila. for 1873, p. 201.Davidson, Mon. Rec. Brach., pt. 3, p. 200, pl. 26, figs. 18-22,1888.

Pelagodiscus atlanticus DAll, Bull. Mus. Comp. Zoöl., vol. 43, pt. 6, p. 440, 1908; Annot. List. Rec. Brach. Nat. Mus., p. 280, 1920.

Off Fernandina and in both Atlantic and Pacific Oceans in depths down to 2,995 fathoms.

\section{MOLLUSCA}

\section{PELECYPODA}

\section{Family NUCULIDAE}

\section{Genus NUCULA Lamarck}

NUCULA CULEBRENSIS E. A. Smith

Nucula culebrensis E. A. Sмiтн, Challenger Pelecypoda, p. 228, pl. 18, figs. 11, 11a., 1885.

Off Georgia and Fernandina, rather common; off Culebra Island in 390 fathoms at station 24 of the Challenger expedition.

The teeth average 7 and 14 on the two sides of the beak; the young shells hardly indicate the minute crenulations of the margin which are developed in the adults. Nucula crenulata A. Adams, from Guadeloupe may be identical with this species but in the absence of authentic specimens of crenulata it seems safer to adopt Smith's name about the application, of which there is no doubt. The margin of the escutcheon is usually crenulate. 
Shell resembling $N$. culebrensis in sculpture but less emphatic, the form much more trigonal and relatively more inflated, the marginal crenulations coarser, the escutcheon feebly impressed with no distinct limits and no bordering crenulation. Length, 4 ; height, 3.6; diameter, $2.25 \mathrm{~mm}$. U. S. Nat. Mus. Cat. No. 108198.

Off Fernandina, two specimens and one larger valve. The teeth numbered 8 and 11; the beaks are particularly prominent. From the variety obliterata of $N$. crenulata it differs by form, by greater solidity, and apparently by smaller size. Both forms are distinctly more trigonal than $N$. crenulata A. Adams, but the present one especially so.

\section{NUCULA VERRILLII Dall}

Nucula trigona Verrill, Trans. Conn. Acad., vol. 6, p. 438, 1885; not of Bronn, 1849.

Nucula verrillii Dall, Bull. Mus. Comp. Zoöl., vol. 12, p. 248, 1886; Proc. U. S. Nat. Mus., vol. 12 , p. 257, pl. 14, fig. 4, 1889.-Verrill and Bush, Proc. U. S. Nat. Mus., vol. 20, p. 853, pl. 95, fig. 10, 1898.

Off Fernandina and Georgia, north to latitude $39^{\circ} 44^{\prime}$ and south to Yucatan, in 294 to 1,825 fathoms.

This occurs in moderate numbers.

\section{NUCULA PROXIMA OVATA Verrill}

Nucula proxima (Say), variety ovata Verrill, Proc. U.S. Nat. Mus., vol. 20, No. 1139, p. 852, pl. 81, fig. 6, pl. 88, fig. 5, 1898.

Off Georgia, and in Vineyard Sound off Cuttyhunk, in 18 fathoms (Verrill).

One valve apparently referable to this form was dredged off Georgia.

\section{Family LEDIDAE}

\section{Genus LEDA Schumacher \\ Section LEDELLA Verrill}

LEDA MESSANENSIS Seguenza

Leda acuminata Jefrreys, Ann. Mag. Nat. Hist., July, 1870, p. 69.-SeGUEnza, Nuc. Terz., p. 1175 pl. 3, figs. $15 a-15 e$. not of von Buch, 1849.

Leda messanensis Seguenza, Nuc. Terz., p. 1175.-Jeffreys, Proc. Zool. Soc., June 17, 1879, p. 576, 1880.

Off Georgia and Fernandina, not uncommon. South to Barbados in depth from 100 to 1,002 fathoms.

\section{LEDA ORIXA, new species}

Shell small, smooth, equivalve, nearly equilateral, rounded in front, acute behind, with a slight flexure in front of the rostrate end, the 
beaks inconspicuous, slightly nearer the posterior end, the surface dull, rarely with a few concentric markings; the resilifer minute, the hinge with 14 anterior and about 7 posterior teeth. Length, 4 ; height, 2.25; diameter, 1.5 mm. U.S. Nat. Mus. Cat. No. 108190.

Off Fernandina, rather common.

The shell is close to L. hebes E. A. Smith, from near Culebra Island, which has the posterior end longer than the anterior and wants the flexure in front of the rostrum.

LEDA ASPECTA, new name

Ledella parva Verrill and Bush, Amer. Journ. Sci., vol. 3, p. 54, fig. 18, Jan., 1897; Proc. U.S. Nat. Mus., vol. 20, No. 1139, p. 857, pl. 81, fig. 1, 1898.

Off Georgia and Fernandina, numerous specimens. Off Marthas Vineyard in 525 fathoms, Verrill.

There is no defined escutcheon. Not. L. parva Sowerby, 1833.

LEDA BIPENNIS, new species

Shell small, smooth, not flexed behind, the beaks inconspicuous, the anterior end rounded, the basal margin nearly straight, the posterior slope longer, descending to a subtruncate end of the shell; resilifer minute, not projecting, teeth about 10 on each side of it; there is no indication of an escutcheon. Length, 4.5; height, 3 ; diameter, $2.1 \mathrm{~mm}$. U. S. Nat. Mus. Cat. No. 108187.

Off Fernandina, rare.

\section{Genus YOLDIELLA Verrill and Bush}

YOLDIELLA PYGMAEA Münster

Nucula pygmaea MÜNSTeR in Goldfuss, Petr. Germ., vol. 2, p. 157, pl. 125, fig. 17, 1842.

Leda pygmaea Orbigny, Prodr. Pal., vol. 2, p. 378, 1852.

Leda (Portlandia) pygmaea Hanlex, Mon. Nuculidae (in Sowerby, Thes. Conch.), p. 41, pl. 2, figs. 26, 27, 1860.

Off Fernandina, rather common.

There seems to be some difference of opinion as to whether the recent shell is identical with Münster's fossil form, but at any rate the present species has been identified with the latter by Hanley, Jeffreys, and Marshall, as indicated by specimens received from them.

\section{Y OLDIELLA FRATERNA Verrill and Bush}

Yoldiella fraterna Verrill and Bush, Proc. U. S. Nat. Mus., vol. 20, No. 1139, p. 867, pl. 80, fig. 5; pl. 82, fig. 8, 1898.

Off Georgia, seven specimens. Off the Atlantic coast from latitude $37^{\circ}$ to latitude $47^{\circ}$ in 90 to 1,608 fathoms; Verrill.

$24105-27 \dagger-2$ 


\section{Subfamily MaLletinnae}

\section{Genus MALLETIA Desmoulins}

\section{Section NEILO Adams}

\section{Malletia Dilatata Philippi}

Nucula dilatata Philippi, Moll. Sicil., vol. 2, p. 47, pl. 15, fig. 7, 1844.

Neilo dilatata Seguenza, Nucul. Terz., p. 1184, 1877.

Malletia (Neilo ?)dilatata Dall, Bull. Mus. Comp. Zoöl., vol. 9, No. 2, p. $255,1881$.

Off Fernandina, two valves. Off Morro Light, Havana, in 292 fathoms, U. S. S. Blake.

\section{Genus TINDARIA Bellardi}

TINDARIA CYTHEREA Dall

Nucula (Tindaria?) cytherea DALL, Bull. Mus. Comp. Zoöl., vol. 9, p. 123, 1881; vol. 12 , No. 6 , p. 254.

Malletia veneriformis E. A. Sмгтн, Challenger Pelecypoda, p. 246, pl. 20, figs. $9,9 a, 1885$.

Off Fernandina, not rare. Gulf of Mexico and eastward to St. Vincent, United States Fish Commission.

\section{TINDARIA ACINULA Dall}

Malletia (Tindaria) acinula DALL, Proc. U. S. Nat.Mus., vol. 12 , No. 773, p. 253 , pl. 13, fig. 4,1889 .

Tindariopsis (? Neilonella) acinula DaLL, Trans. Wagner Inst., vol. 3, pt. 4, p. 582.-Verrill and Bush, Proc. U. S. Nat. Mus., vol. 20, No. 1139, p. 881,1898 .

Shell small, smooth except for incremental lines, whitish, inflated, the anterior end shorter, evenly rounded; posterior end longer, pointed, the dorsal slope sharp, the base arcuate; erect; ligament dividing the hinge line, teeth about 10 on each side; pallial line with a slight indentation near the posterior scar. Length, 5.0; height, 3.5; diameter, $3 \mathrm{~mm}$. U. S. Nat. Mus. Cat. No. 108195.

Off Fernandina, a dozen valves. East of Tobago in 880 fathoms; south of St. Kitts, 687 fathoms; and 98 miles north of Ceara, Brazil, in 1,019 fathoms; U. S. S. Albatross.

\section{Genus PSEUDOGLOMUS Dall \\ PSEUDOGLOMUS POMPHOLYX Dall}

Yoldia pompholyx Dall, Proc. U. S. Nat. Mus., vol. 12, No. 773, p. 255, pl. 13, fig. 8, 1889.

Tindaria (Pseudoglomus) pompholyx DALL, Trans. Wagner Inst., vol. 3, pt. 4, p. 582, 1898.

Off Fernandina, nine valves.

Externally like Pristigloma, but without the internal resilium of that genus; with a central external short ligament and more substantial hinge teeth, about seven anterior and nine posterior in the adult. 


\section{Genus PRISTIGLOMA Dall, 1900}

PRISTIGLOMA NITENS Jeffreys

Glomus nitens Jeffreys, Ann. Mag. Nat. Hist., Nov. 1876, p. 433.-Verrill and Bush, Amer. Journ. Sci., vol. 3, pp. 53, 59, Jan. 1897; Proc. U.S. Nat. Mus., vol. 20, No. 1139, p. 848, pl. 97, figs. 1, 2, 1898 . (Not Glomus Gistel, 1848.)

Off Fernandina, one valve. From off Martha's Vineyard south to Rio de la Plata in 1,504 to 1,900 fathoms, U. S. S. Albatross.

This curious form seems intermediate between forms like Pseudoglomus and Limopsis. The minute wrinkles indicated as "lateral teeth" do not occur on other specimens than Verrill's type and are possibly an individual development. At any rate they are barely perceptible under the microscope and may be pathological.

\section{Family ARCIDAE}

\section{Genus LIMOPSIS}

\section{LIMOPSIS TENELLA Jeffreys}

Limopsis tcnella Jeffreys, Ann. Mag. Nat. Hist., Nov. 1876, p. 433.DAll Bull. Mus. Comp. Zoöl., vol. 9, p. 118, 1881; vol. 12, No. 6, p. $236,1886$.

Off Fernandina, a few young specimens.

This species was dredged in immense numbers off the Florida coast and among the Antilles by Mr. J. B. Henderson; and by the Albatross as far south as Puerto Gallegos in southern Argentina, latitude 51 ${ }^{\circ}$ south, and in depths from 50 to 700 fathoms.

\section{LIMOPSIS MINUTA Philippi}

Pectunculus minutus Philippi, Moll. Sicil., vol. 1, p. 63, pl. 5, fig. 3, 1836; vol. 2, p. $45,1844$.

Limopsis borealis WoodWARD, teste Jeffreys.

Limopsis minuta Dall, Bull. Mus. Comp. Zoöl., vol. 9, No. 2, p. 119, 1881; vol. 12, No. 6, p. 236, 1886.-Verrill, Proc. U. S. Nat. Mus., vol. 20, No. 1139, p. 846, pl. 75, fig. 1; pl. 78, fig. 7, 1898.

Off Georgia and Fernandina. South to the lesser Antilles in 30 to 2,221 fathoms.

\section{LIMOPSIS RADIALIS, newispecies}

Shell minute, white, subovate, moderately convex, with the inner margins minutely crenate; beaks small, prominent; hinge line short, teeth on each side few, small, somewhat radially arranged; sculpture of low small regular concentric rounded ridges crossed by about a dozen widely spaced rather prominent radial threads. Length, 3.7; height, 3.8; diameter, 2; hinge line, $2 \mathrm{~mm}$. U. S. Nat. Mus. Cat. No. 108184.

Off Fernandina, four valves.

The sculpture is somewhat like that of L. antillensis Dall, but the form and hinge quite different. 
Shell small, narrow, oblique, inflated, the beaks prominent, the inner margins crenulate; area rather large; hinge line short, with four oblique teeth on the shorter side and eight more vertical on the other; sculpture of numerous fine equal radiating threads with equal or narrower interspaces; concentric sculpture only of faint incremental ines. Length, 5.0 ; height, 5.5 ; diameter, 4 ; hinge line, $3.5 \mathrm{~mm}$. U.S. Nat. Mus. Cat. No. 108183.

Off Fernandina, two valves.

I have been unable to find any recent species closely resembling this.

\section{Genus CUCULLARIA Conrad}

CUCUllaria Sagrinata Dall

Macrodon sagrinata DALL, Bull. Mus. Comp. Zoöl., vol. 12, No. 6, p. 245, September, 1886.

Arca (Cucullaria) sagrinata DALL, Trans. Wagner Inst., vol. 3, pt. 4, p. 659, 1898; Proc. U. S. Nat. Mus., vol. 24, No. 1264, p. 508, pl. 31, fig. 2, March, 1902.

Off Fernandina and Georgia; numerous valves. Gulf of Mexico, in 80 fathoms, U. S. S. Albatross.

\section{Genus ARCA Linnaeus}

\section{Subgenus Barbatia (Gray) Adams}

BARBATIA, sp. indet.

Off Fernandina, three very young valves.

These, though undoubtedly belonging to Barbatia, are too young to determine the species.

\section{Subgenus BathyarCa Kobelt \\ BATHYARCA ORBICULATA Dall}

Bathyarca pectunculoides, var. orbiculata DALL, Bull. Mus. Comp. Zoöl., vol. 9 , p. 121 ; vol. 12 , No. 6 , p. 240 , pl. 8 , fig. $5,1886$.

Off Georgia and Fernandina. Gulf of Mexico, at Blake Station 33, in 1,568 fathoms.

BATHYA RCA INAEQUALIS, new species

Shell minute, white, translucent, very inequilateral, the anterior end short, attenuated, rounded, the posterior longer, widely expanded, rounded; beaks prominent, small; area nearly linear, hinge line with three very oblique teeth at each end separated by a long edentulous space; inner margins smooth; sculpture very faintly cancellate by incremental and radial striae, more evident toward the ends and basal 
edges of the valve. Length, 3.5; greatest vertical measure, 2.75; diameter, $2.2 \mathrm{~mm}$. U. S. Nat. Mus. Cat. No. 108179.

Off Fernandina, one value.

This is nearest to B. frielei Jeffreys, but is smaller and relatively longer. Its form recalls Dacrydium vitreum.

\section{Family PECTINIDAE}

\section{Genus PECTEN Müller}

\section{Subgenus Pseudamusium Adams}

\section{PSEUDAMUSIUM NANUM Verrill and Bush}

Cyclopecten nanus Verrill and Bush, Trans. Conn. Acad., vol. 10, pp. 85, 92, pl. 16, figs. 12, 12 c., 1897; Proc. U. S. Nat. Mus., vol. 20, No. 1139, p. 837, pl. 85, figs. 2-4, 1898.

Off Fernandina, three valves. Atlantic coast to North latitude $37^{\circ}$ in 43 to 132 fathoms, United States Fish Commission.

\section{Subgenus Propeamusium Gregorio \\ PROPEAMUSIUM POURTALESIANUM Dall}

Amusium (Propeamusium) pourtalesianum Dall, Bull. Mus. Comp. Zoöl., vol. 12, No. 6, p. 211, pl. 4, fig. 3; pl. 5, fig. 12, 1886.

From off Fernandina and the Gulf of Mexico south to the lesser Antilles, in depths living, from 13 to 805 fathoms, and temperatures from $39.5^{\circ}$ to $82.5^{\circ} \mathrm{F}$.

\section{Family LIMIDAE}

\section{Subgenus Limatula S. Wood \\ LIMATULA LAMINIFERA E. A. Smith}

Lima (Limatula) laminifera E. A. Sмгтн, Challenger rept. Pelecypoda, p. 293, pl. 24, figs. 7, 7 a., 1885.

Off Fernandina, one valve. Off Sombrero, in 450 and off Culebra in 390 fathoms, Challenger expedition.

\section{Genus LIMAEA Bronn}

LIMAEA BRONNIANA Dall

Limaea bronniana Dall, Bull. Mus. Comp. Zoöl., vol. 12, No. 6, p. 226, 1886; Proc. U. S. Nat. Mus., vol. 12, p. 251, pl. 14, fig. 9, 1889.

Off Fernandina, one valve. North Carolina to Barbados in 15 to 804 fathoms; United States Fish Commission. 


\section{Family POROMYACIDAE}

\section{Genus POROMYA Forbes}

POROMYA GRANULATA Nyst and Westendorp

Corbula? granulata Nyst and Westendorp, Nouv. Recherch. Coq. Foss. d'Anvers, p. 6, pl. 3, fig. 3, 1839.

Poromya anatinoides Forbes, Rep. Brit. Assoc., 1843, p. 191.

Poromya granulata Forbes and Hanley, Brit. Moll., vol. 1, p. 204, pl. 9, figs. 4, 5, 6, 1853.

Off Fernandina, three valves. Florida Keys and the Antillean region in 15 to 227 fathoms, in temperatures $46^{\circ}$ to $60^{\circ} \mathrm{F}$.

\section{Family VERTICORDIIDAE}

\section{Genus LYONSIELLA M. Sars}

LYONSIELLA ABYSSICOLA SarS

Lyonsiella abyssicola M. SARs, Rem. forms Anim. life, p. 25, pl. 3, figs. 21-43, 1872.

Off Fernandina, three valves. Widely distributed in the deep water of the North Atlantic.

\section{Genus VERTICORDIA Wood}

Verticordia Wood, in Sowerby, Min. Conch., pl. 639, August, 1844.

\section{Section VERTICORDIA s. s.}

\section{VERTICORDIA SEGUENZAE Dall}

Verticordia seguenzae DALL, Bull. Mus. Comp. Zoöl., vol. 12, No. 6, p. 290, 1886.

Off Fernandina and Georgia, rather rare. North Carolina to Yucatan straight in 124 to 640 fathoms, United States Fish Commission.

\section{Section TRIGONULINA Orbigny}

VERTICORDIA ORNATA Orbigny

Trigonulina ornata OrBigny, Moll. Cuba, vol. 2, p. 292, pl. 27, figs 30-33, 1846.

Verticordia ornata DALL, Bull. Mus. Comp. Zoöl., vol. 9, p. 105, 1881.

Verticordia caelata Verrill, Trans. Conn. Acad., vol. 5, p. 566, 1884; vol. 6, pl. 30 , fig. 9 .

Off Fernandina and Georgia. Martha's Vineyard to Barbados; California; Japan and China Seas; United States Fish Commission.

\section{Family LEPTONIDAE}

\section{Genus MONTACUTA Turton}

Montacuta limpida DALL, Proc. U. S. Nat. Mus., vol. 21, p. 894, pl. 87, figs. 5, 11, 1899 . 
One valve off Fernandina; one off Cape Florida in the Gulf of Mexico, in 85 fathoms.

\section{Genus ERYCINA Lamarck \\ ERYCINA FERNANDINA Dall}

Erycina fernandina Dall, Proc. U. S. Nat. Mus., vol. 21, p. 887, pl. 88, fig. 6, 1889.

Off Fernandina, one specimen.

\section{Family THYASIRIDAE \\ Genus THYASIRA (Leach) Lamarck \\ Section AXINULUS Verrill and Bush}

THYASIRA SUCCISA Jeffreys

Thyasira succisa Jeffreys, Ann. Mag. Nat. Hist., vol. 19, Dec. 1876, p. 492 Off Fernandina, two valves.

\section{Family KELLIELLIDAE \\ Genus KELLIELLA Sars \\ KELLIELLA NITIDA Verrill}

Kelliella nitida Verrill, Trans. Conn. Acad., vol. 6, p. 438, 1885; Proc. U. S. Nat. Mus., vol. 20, No. 1139, p. 778, pl. 91, fig. 8; pl. 93, fig. 10, 1898.

Off Fernandina, eight valves. From north latitude $39^{\circ} 5^{\prime}$ south to latitude $38^{\circ} 20^{\prime}$ in 1,525 to 2,033 fathoms; United States Fish Commission.

\section{Family CUSPIDARIIDAE \\ Genus CUSPIDARIA Nardo \\ CUSPIDARIA ARCTICA Sars}

Neaera arctica G. O. SArs, Moll. Reg. Arct. Norv., p. 85, pl. 6, figs. $5 a-5 c, 1878$.

Off Fernandina, one valve. North Atlantic, Sars and Verrill.

\section{CUSPIDARIA, sp. indet}

A single right valve resembling $C$. gracilis in form but more polished and with half a dozen fine radial threads on the rostrum; the resilifer is prominent and directed forward, the hinge is edentulous. In the absence of the other valve it seems best to leave it unnamed. Length, 11; height, 7; diameter, $4.3 \mathrm{~mm}$. U. S. Nat. Mus. Cat. No. 108209.

Off Fernandina, one right valve. In the extensive collection of the genus in the National collection I was unable to match this valve.

\section{Genus HALONYMPHA DALl AND SMith}

\section{HALONYMPHA Claviculata Dall}

Neaera claviculata Dall, Bull, Mus. Comp. Zoöl., vol. 9, p. 112, 1881.- Вмітн, Challenger Pelecypoda, p. 52 (not pl. 9, figs. 8, 8 b.) 1885. 
Halonympha claviculata Dall, Bull. Mus. Comp. Zoöl., vol. 12, No. 6, p. 301, pl. 2, figs. 2, 2 a., 1886.

Off Fernandina, two valves. Also near Bermuda in 435 fathoms, and off Havana in 450 fathoms.

\section{Family ASTARTIDAE \\ Genus ASTARTE J. Sowerby \\ ASTARTE GLOBULA Dall}

Astarte smithi, var. globula DaLL, Bull. Mus. Comp. Zoöl., vol. 12, No. 6, p. $260,1886$.

Astarte globula Dall, Proc. U. S. Nat. Mus., vol. 24, No. 1264, p. 508, pl. 32, fig. 6, March, 1902.

Off Fernandina, numerous specimens. At various localities in the Antilles; United States Fish Commission.

\section{Family MESODESMATIDAE}

\section{Genus ERVILIA Turton}

ERVILIA CONCENTRICA Gould

Ervilia concentrica Gould, Proc. Boston Soc. Nat. Hist., vol. 8, p. 281, Feb., 1862; Otia Conch., p. 239, 1862.

Off Georgia. Off the coast of North Carolina; Gould.

\section{Family PHOLADIDAE \\ Genus DIPLOTHYRA Tryon \\ DIPLOTHYRA SMITHII Tryon}

Diplothyra smithii Tryon, Proc. Acad. Nat. Sci. Phila., 1862, p. 450, text figure, September, 1862.

Off Fernandina, one valve; Staten Island, Tryon.

\section{SCAPHOPODA}

\section{Family DENTALIIDAE}

\section{Genus DENTALIUM}

\section{Section ANTALIS H. and A. Adams}

\section{DENTALIUM CERATUM Dall}

Dentalium ceratum DALI, Bull. Mus. Comp. Zoöl., vol. 9, p. 38, 1881; vol. 18 , p. 424 , pl. 26 , fig. 5 ; pl. 27 , fig. 2, 1889.-Henderson, Bull.

U. S. Nat. Mus. No. 111, p. 50, pl. 7, figs. 2, 4, 5, 6, 7, 1920.

Off Fernandina. Also from the Florida Keys to Barbados in 60 to 805 fathoms, temperatures $39.75^{\circ}$ to $46.75^{\circ} \mathrm{F}$. 


\section{DENTALIUM TUBULATUM Henderson}

Dentalium tubulatum Henderson, Bull. U. S. Nat. Mus. 111, p. 56, pl. 8, fig. 5, 1920.

Off Fernandina. Also off Bahia Honda, Cuba, in 220 fathoms, temperature $62^{\circ}$ F., U. S. S. Blake.

\section{Section BATHOXIPHUS Pilsbry and Sharp}

\section{DENTALIUM ENSICULUS Jeffreys}

Dentalium ensiculus Jefereys Ann. Mag. Nat. Hist., ser. 4, vol. 19, p. 154, 1877; Proc. Zoöl. Soc., 1882, p. 660, pl.49, fig. 4.-Henderson, Bull. U. S. Nat. Mus. 111 , p. 81 , pl. 14 , figs. $1,4,5,7,9,1920$.

Dentalium sigsbeanum Dall, Bull. Mus. Comp. Zoöl., voI. 9, p. 38, 1881.

Off Fernandina. Georges Bank to St. Bart's and the Yucatan Strait, United States Fish Commission and the U. S. S. Blake. Eastern Atlantic, Jeffreys. Found in 193 to 1,859 fathoms; temperature $37^{\circ}$ to $51.6^{\circ} \mathrm{F}$.

\section{Section COMPRESSIDENS Pilsbry and Sharp}

\section{DENTALIUM PRESSUM Pilsbry and Sharp}

Dentalium compressum WAtson, Journ. Linn. Soc. London, vol. 14, p. 516, 1879 (not of Orbigny, 1850); Challenger Scaphopoda, p. 9, pl. 1, fig. 9, 1885.

Dentalium (Compressidens) pressum PILSBry and Sharp, in Tryon, Man. Conch., vol. 17, p. 124, pl. 7, fig. 11 ; pl. 22, figs. 50-52, 1897.-HeNDerson, Bull. U. S. Nat. Mus. 111, p. 83, pl. 14, figs. 3, 6, 8, 1920.

Off Fernandina. Florida Keys, Gulf of Mexico and Cape San Antonio; off Culebra Island, Challenger expedition. In 100 to 339 fathoms, temperature $43.4^{\circ}$ to $51.6^{\circ} \mathrm{F}$.

\section{DENTALIUM OPHIODON Dall}

Dentalium ophiodon Dall, Bull. Mus. Comp. Zoöl., vol. 9, p. 38, 1881; vol. 18, p. 427, pl. 26, fig. 9, 1889.-Henderson, Bull. U. S. Nat. Mus. 111, p. 84 , pl. 14, fig. 2, 1920.

Off Fernandina. Florida Keys to Barbados, in 70 to 287 fathoms.

\section{Genus SIPHONODENTALIUM Sars}

\section{Section ENTALINA Monterosato}

\section{SIPHONODENTALIUM PLATAMODFS Watson}

Siphodentalium platamodes Watson, Journ. Linn. Soc. London, vol. 14, p. 519, 1879; Challenger Scaphopoda, p. 13, pl. 2, fig. 4, 1885.

Entalina platamodes Henderson, Bull. U. S. Nat. Mus. 111, p. 87, pl. 15, figs. 1, 4, 5, 7, 1920.

Off Fernandina. Rebecca shoals in 430 fathoms, Rush. 


\section{SIPHONODENTALIUM STRIATINUM Henderson}

Siphonodentalium striatinum Henderson, Bull. U. S. Nat. Mus. 111, p. 90, pl. 16, figs. 3, 8, 1920.

Off Fernandina.

\section{Genus CADULUS Philippi}

\section{Section PLATYSCHIDES Henderson}

\section{CADULUS PROVIDENSIS Henderson}

Cadulus (Platyschides) providensis Henderson, Bull. U. S. Nat. Mus. 111, p. 122, pl. 18, fig. 14, 1920.

Off Fernandina. Also off Old Providence Island in 380 fathoms, sand; temperature $45.75^{\circ} \mathrm{F}$. United States Fish Commission.

\section{Section GADILA Gray}

\section{CADULUS RASTRIDENS Watson}

Cadulus rastridens WAtson, Journ. Linn. Soc. London, vol. 14, p. 525, 1879;

Challenger Scaphopoda, p. 19, pl. 3, fig. 3, 1885.-Henderson, Bull.

U. S. Nat. Mus. 111, p. 132, pl. 19, fig. 1, 1920.

Off Georgia and Fernandina. Off Culebra Island, in 390 fathoms, Challenger expedition.

\section{CADULUS REgULARIS Henderson}

Cadulus (Gadila) regularis Henderson, Bull. U. S. Nat. Mus. 111, p. 137, pl. 19, fig. 14, 1920.

Off Georgia and Fernandina. Also off Cape Canaveral, Florida, in 504 fathoms, temperature $45.7^{\circ} \mathrm{F}$.

\section{CADULUS ACUS Dall}

Cadulus acus DalL, Bull. Mus. Comp. Zoöl., vol. 18, p. 432, pl. 27, fig. 11, 1889.

Cadulus (Gadila) acus Henderson, Bull. U. S. Nat. Mus. 111, p. 140, pl. 20, figs. 11, 13, 1920.

Off Fernandina. Also Mayaguez Harbor, Porto Rico, in 25 fathoms, temperature $75.8^{\circ} \mathrm{F}$. St. Thomas, 5 fathoms; Santo Domingo ; and the coast of Guatemala and British Honduras.

\section{Section CADULUS s. s.}

\section{CADULUS TRANSITORIUS Henderson}

Cadulus transitorius Henderson, Bull. U. S. Nat. Mus. 111, p. 143, pl. 19, fig. $6,1920$.

Off Fernandina. Also Gulf of Mexico and south to Old Providence Island, in 90 to 660 fathoms, temperature $45.7^{\circ}$ and $46.3^{\circ} \mathrm{F}$. 


\section{CADUlUS OBESUS Watson}

Cadulus obesus Watson, Journ. Linn. Soc. London, vol. 14, p. 527, 1879; Challenger Scaphopoda, p. 22, pl. 3, fig. 8, 1885.-Henderson, Bull. U.S. Nat. Mus. 111, p. 146, pl. 20, fig. 8, 1920.

Off Fernandina. Bahia Honda, Cuba, in 200 fathoms, United States Fish Commission. Off Culebra Island in 390 fathoms; Watson.

\section{CADUlus Platensis Henderson}

Cadulus platensis Henderson, Bull. U.S. Nat. Mus. 111, p. 147, pl. 20, fig. $14,1920$.

Off Georgia and Fernandina. Off Ceará, Brazil, in 1,019 fathoms, temperature $39.5^{\circ} \mathrm{F}$, and off Rio de la Plata in $11 \frac{1}{2}$ fathoms, United States Fish Commission.

This is C.tumidosus Dall, 1889, not of Jeffreys, 1877.

\section{GASTROPODA TECTIBRANCHIATA}

\section{Family ACTEONIDAE \\ Genus ACTEON Montfort ACTEON DANAIDA Dall}

Actaeon danaida Dall, Bull. Mus. Comp. Zoöl., vol. 9, p. 96, 1881; vol. 18, p. 42, pl. 17, fig. 12, 1889 .

Off Fernandina. Also off the Tortugas in 339 fathoms, temperature $45^{\circ} \mathrm{F}$.

\section{ACTEON INCISUS Dall}

Actaeon incisus DALL, Bull. Mus. Comp. Zoöl., vol. 9, p. 95, 1881; vol. 18, p. 42 , pl. 17, figs. $1,1 b ., 1889$.

Off Fernandina, 10 specimens. Yucatan Strait, 640 fathoms.

\section{ACTEON HEBES Verrill}

Actaeon hebes Verizllu, Trans. Conn. Acad., vol. 6, p. 428, pl. 44, fig. 15, 1885.

Off Georgia, two young specimens. Off North Carolina in 2,574 fathoms, temperature $36.8^{\circ} \mathrm{F}$.

\section{ACTEON SEMICINGULATA new species}

Shell small, translucent white, with a blunt immersed apex and about four visible whorls; surface finely spirally striated on the anterior half of the last whorl; suture distinct, very slightly shouldered; whorls moderately rounded, the last twice as long as the spire; aperture sublunate, slightly produced in front; outer lip thin, sharp, moderately arcuate; pillar lip thin with a hardly perceptible fold; a 
narrow channel behind it. Height, 3 ; maximum diameter, $1.5 \mathrm{~mm}$. U. S. Nat. Mus. Cat. No. 107913.

Off Fernandina, five specimens.

ACTEON PARTICOLOR, new species

Shell small, short, rotund, smooth, white with three brownish spiral bands on the last whorl; apex blunt, nucleus completely immersed, visible whorls about four, moderately rounded, separated by a distinct suture; aperture sublunate, outer lip thin, sharp, arcuate, rounding evenly in front to the slightly thickened strongly twisted pillar behind which is a minute chink; the last whorl comprises most of the shell. Height of shell, 3.5; of last whorl, 2.8; diameter, $2 \mathrm{~mm}$. U. S. Nat. Mus. Cat. No. 108274.

Off Georgia, one specimen.

The brown bands are liable to fade in the cabinet, even if kept in the dark.

\section{ACTEON JUVENIS, new species}

Shell minute, white, with a bluntly immersed nucleus and four moderately convex whorls; suture channelled with the whorl in front of it minutely narrowly tabulate; sculpture of (on the last whorl about a dozen) spiral conspicuously punctuate uniform grooves, covering the whorl; base imperforate, pillar with a feeble obscure plait lagging behind the aperture; outer lip thin, aperture narrowly ovate. Height, 3; diameter, 2 mm. U. S. Nat. Mus. Cat. No. 107915.

Off Fernandina, four specimens.

The sculpture resembles that of $A$. hebes, jr., but the shell is much more slender.

ACTEON LIOSTRACOIDES, new species

Shell small, translucent white, slender, with a blunt apex and nearly six whorls; surface polished, smooth except for microscopically fine spiral striae over the whole surface, stronger on the base; suture appressed, distinct, sides flatly compressed, the last whorl longer than the spire; aperture narrow, about two-thirds the length of the last whorl; outer lip sharp, thin, slightly arcuate, rounding evenly into the short slightly thickened arcuate pillar which carries an obscure fold; body without enamel. Height, 7 ; maximum diameter, $2.7 \mathrm{~mm}$. U. S. Nat. Mus. Cat. No. 107917.

Off Fernandina, 15 specimens.

At first sight this shell might be mistaken for a Melanella. Its nearest relative seems to be $A$. nitidus Verrill, than which it is more slender, acute, and flat-sided.

\section{ACTEON PROPIUS, new species}

Shell small, white, rather slender, with a large bluntly immersed nucleus, distinct slightly shouldered suture and about five moderately 
convex whorls; sculpture of evident incremental lines and microscopically minute spiral striation; aperture half as long as the shell, narrowly ovate, the pillar twisted but not distinctly plicate; base imperforate; length, 4.3; diameter, $1.7 \mathrm{~mm}$. U. S. Nat. Mus. Cat. No. 107919.

Off Fernandina, two specimens.

This resembles $A$. nitidus but has the aperture longer in proportion to the total length, the suture slightly turrited and the spiral striation finer.

\section{ACTEON PARALLELUS, new species}

Shell minute, white, subcylindrical, with an immersed blunt apex and nearly four whorls; suture distinct, briefly shouldered; surface finely spirally striate, the striae microscopically reticulate by faint incremental lines; sides of the last whorl nearly flat, the base short, evenly rounded; outer lip thin, sharp, straight, anteriorly rounded into the slightly thickened and twisted pillar; base imperforate in the adult, a slight chink behind the pillar in immature specimens. Height, 3; maximum diameter, $1.5 \mathrm{~mm}$. U. S. Nat. Mus. Cat. No. 107918.

Off Georgia and Fernandina, four specimens.

This is remarkable for its subcylindrical turrited whorls.

ACTEON LACUNATUS, new species

Shell small, solid, pale gray, of somewhat more than four whorls, with an immersed nucleus; apex blunt, suture distinct, not channelled, whorls only moderately convex; axial sculpture chiefly visible in the grooves, strongly reticulating them; spiral sculpture of (on the last whorl about 16) channelled deep grooves with about equal interspaces over the whole surface; aperture about half as long as the shell, outer lip simple, arcuate, rounding in front into a conspicuously thickened almost folded, short pillar, with an obvious coat of enamel across the body, the base imperforate. Length, 3; diameter, $1.8 \mathrm{~mm}$. U. S. Nat. Mus. Cat. No. 108273.

Off Georgia, three specimens.

The spiral sculpture of channelled grooves is coarser than in any of the other forms mentioned.

A defective specimen found with the above (108273b.) has an acute rapidly enlarging spire, spiral punctate sculpture and a conspicuous groove in front of the suture on all five whorls; the last whorl much the largest. The base is imperforate. Length, 3 ; diameter $2 \mathrm{~mm}$. 


\section{Family RINGICULIDAE}

\section{Genus RINGICULA Deshayes \\ Section RINGICULINA Monterosato}

\section{RINGICULA NITIDA Verrill}

Ringicula nitida Verrill, Amer. Journ. Sci., ser. 3, vol. 5, p. 16, Jan., 1873; Trans. Conn. Acad., vol. 3, p. 48, pl. 1, fig. 2, 1874.

Ringicula leptocheila Brugnone, Misc. Malac., p. 18, fig. 11, 1873.

Off Georgia and Fernandina, numerous. Gulf of Maine to the Lesser Antilles, and on both sides of the Atlantic, in the Mediterranean and fossil in the Italian Pliocene.

\section{Family ACTAEONIDAE \\ Genus OVULACTAEON Dall \\ OVULACTAEON MEEKI Dall}

Ovulactaeon meeki Dall, Bull. Mus. Comp. Zoöl., vol. 18, p. 43, pl. 33, figs. 3, 4, 1889.

Off Fernandina, 14 specimens. Also off Havana in 450 fathoms (Sigsbee), and west of North Bimini, Bahamas, in 200 fathoms, sand; Dr. W. H. Rush.

\section{- Family ACTEOCINIDAE}

\section{Genus VOLVULELLA Newton}

VOLVULELLA MÖRCHI, new species

Shell small, white, smooth, subcylindric, attenuated at both ends, involved, the aperture as long as the shell; apex hardly pointed, aperture very narrow except in front; outer lip thin, straight, rounding in front evenly into the short twisted pillar which is hardly thickened and has a narrow furrow behind it. Height, 3.5; diameter, $1.25 \mathrm{~mm}$. Cat. No. 108268, U. S. N. M.

Off Georgia, one specimen.

The shell is nearest $V$. persimilis Mörch, but is smaller and not spirally striated.

\section{Genus RETUSA Brown}

RETUSA RECTA Orbigny?

? Bulla recta Orbigny, Moll. Cuba, vol. 1, p. 131, pl. 4bis. figs. 17, 20, 1845.

Shell small, white, microscopically spirally striated, with about three whorls, exclusive of the prominent obliquely partly immersed nucleus; suture distinct, the whorl in front of it rather squarely shouldered but not channeled; sides parallel, rounded in front, the aperture narrow behind, with sharp, thin margin, carried back as far as the shoulder of the last whorl; pillar arcuate, simple, without a 
fold. Height, 2.25; diameter, $1.5 \mathrm{~mm}$. U. S. Nat. Mus. Cat. No. 107924.

Off Fernandina, one immature specimen.

Owing to the immaturity of the specimen, the identification is tentative.

\section{Genus CYLICHNA Lovèn}

\section{Section CYLICHNINA Monterosato}

\section{CYLICHNA VERRILLII Dall}

Cylichna verrillii DaLL, Bull. Mus. Comp. Zoöl., vol. 18, p. 54, 1889.

Shell small, slender, translucent white, the aperture as long as the shell, smooth except for faint incremental lines; apex with a shallow funicular pit, the whorls involved; shape nearly cylindrical; outer lip thin, straight, the posterior commissure receding about half a whorl; aperture very narrow except at the anterior end, where it rounds evenly into a very short slightly thickened unfolded pillar; body with hardly a wash of enamel or none; base imperforate. Height 6.5; diameter, 3 mm. U. S. Nat. Mus. Cat. No. 107926.

Off Georgia and Fernandina,numerous specimens. Also off the coast of North Carolina in 50 to 124 fathoms, temperatures $58^{\circ}$ to $75^{\circ} \mathrm{F}$.

\section{Subgenus Pyrunculus Pilsbry}

\section{PYRUNCULUS FLORIDENSIS, new species}

Shell small, white, smooth, polished, the whorls involved, about four in number, the apex with a wide funicular perforation; sculpture only of faint incremental lines most prominent on the sides of the funicle; aperture as long as the shell, very narrow behind; outer lip in the adult nearly straight, broadly rounded in front, thickened on the pillar, which has a conspicuous fold not present in the young; there is a very minute chink behind the pillar lip. Height, 5.5; diameter at apex, 2.5; maximum diameter, $3.7 \mathrm{~mm}$. U. S. Nat. Mus. Cat. No. 107929.

Off Fernandina, numerous specimens.

The larger size, greater rotundity, wider apical opening, and probably the conspicuous fold on the adult pillar, distinguish this from the other species of the locality.

\section{PYRUNCULUS RUSHI, new species}

Shell small, white, polished, subpyriform, the whorls involved, the apex with a deep narrow perforation; the only sculpture consists of inconspicuous incremental lines; the aperture is as long as the shell, the posterior commissure rounded over, the outer lip thin, nearly straight, broadly rounded in front; a slight bulge, not a fold, frequently noticeable where it units with the pillar; a very narrow chink 
usually exists behind the pillar. Height, 3.7 ; diameter at apex, 1.5; maximum diameter, $2.5 \mathrm{~mm}$. U. S. Nat. Mus. Cat. No. 107922.

Off Fernandina, numerous specimens.

The species differs from 107923 by its smaller size, relatively shorter and less attenuated form, and slightly wider posterior part of the aperture. It is dedicated to the late Dr. W. H. Rush, United States Navy, to whom we were indebted for several interesting additions to the deeper water fauna.

\section{PYRUNCULUS MEDIUS, new species}

Shell small, white, polished, smooth, involved, the apex deeply narrowly perforate; the whorl enlarging anteriorly; aperture as long as the shell, very narrow behind, broad in front, the margin thin, sharp, straight, in front evenly rounded in to the slightly thickened straight pillar; the latter has a narrow chink behind it; the posterior commissure of the aperture is evenly rounded over. Height, 5; diameter at apex, 1.5; maximum diameter, $3 \mathrm{~mm}$. U. S. Nat. Mus. Cat. No. 107923.

\section{Off Fernandina.}

There is no clearly defined plait on the three specimens collected, but possibly it may develop later from the slight thickening observable.

\section{PYRUNCULUS CURTUlus, new species}

Shell small, short, stout, whitish, smooth, the apex perforate in the young, closed and funicular in the adult; aperture as long as the shell, the outer lip raised slightly above the level of the spire, the aperture very narrow behind, ample and evenly rounded in front; pillar short, thin, slightly arcuate, showing no indication of a plait; surface feebly marked by incremental lines. Length, 2.6 ; diameter, $1.5 \mathrm{~mm}$. U. S. Nat. Mus. Cat. No. 108266.

Off Georgia, six specimens.

This is the smallest and most thickset relatively, of the east coast species.

\section{Family BULLARIIDAE}

\section{Genus BULLARIA Rafinesque}

\section{BULLARIA INDOLENS, new species}

Shell small, white, smooth, except for faint incremental lines and one or two accidental spiral striae, of about four whorls; apex a funicular pit disclosing the edge of the whorls; form a slender oval; aperture as long as the shell, narrow behind where the lip narrowly curves to the body; outer lip mostly straight, rounded into the thickened pillar which has a marked callosity at its anterior end; a narrow chink lies behind the pillar but the base is imperforate; there is a coating 
of enamel on the body. Height, 7.5; diameter, $4.3 \mathrm{~mm}$. U. S. Nat. Mus. Cat. No. 107928.

Off Georgia and Fernandina, two specimens.

This is very near B. krebsi Dall, but somewhat more slender.

\section{Subgenus Leucophysema Dall}

\section{LEUCOPHYSEMA EBURNEOLA Dall, new name}

Bulla? eburnea DALL, Bull. Mus. Comp. Zoöl., vol. 9, p. 98, 1881; vol. 18, p. 55 , pl. 17, fig. 6,1889 . Not Bulla eburnea A. Adams.

Shell small, ivory white, smooth, polished, with a few faint spiral striae on the base; whorls involved, the apex minutely perforate, the aperture as long as the shell, the margin roundly curved behind, gently arcuate laterally, thin, roundly curved to the short thickened pillar; the adult appears to have the umbilicus closed, younger specimens show a more or less marked perforation; and a somewhat wider apical funicle. Height, 6; diameter, $3.5 \mathrm{~mm}$. U. S. Nat. Mus. Cat. No. 107925.

Off Fernandina, numerous specimens.

\section{LEUCOPHYSEMA ABYSSICOLA DalI}

Shell small, ovate, white, smooth, except for fine spiral striae near the apex; the whorls involved; apex with a shallow dimple; aperture as long as the shell; the posterior commissure narrow; outer lip thin, sharp, moderately arcuate, rounding evenly into the slightly thickened short pillar; base imperforate; body with a thin coat of enamel. Height, 4.5; maximum diameter, $3 \mathrm{~mm}$. U. S. Nat. Mus. Cat. No. 107930.

Off Fernandina, six specimens.

These differ from 107925 in being smaller, proportionately shorter, and more rotund. They are probably the young of the much larger L. abyssicola, though I have received them under the name of $D i$ aphana gemma Verrill, which is of a quite different shape.

\section{Family SCAPHANDRIDAE}

\section{Genus SABATIA Bellardi}

\section{Section SABATINA Dall}

\section{SABATIA BATHYMOPHILA Dall}

Atys ? bathymophila Dall, Bull. Mus. Comp. Zoöl., vol. 9, p. 98, 1881.

Sabatia bathymophila DALL, Bull. Mus. Comp. Zoöl., vol. 18, p. 53, pl. 17, figs. $9,9 b ., 1889$.

Off Georgia and Fernandina, numerous young specimens. Yucatan Strait, and about Cuba, in 734 to 2,805 fathoms; U. S. S. Blake. 


\section{Genus SCAPHANDER Montfort}

SCAPHANDER STIGMATICA, new species

Shell much resembling Scaphander nobilis Verrill, from which it is best distinguished by a differential diagnosis. The body is flatter at the apex, shorter, and consequently has a more rotund appearance; the aperture especially in front, is narrower and less expanded; the sculpture in nobilis comprises small rounded-rectangular punctures between flattened spiral interspaces and concentric threads; in the present species the punctures are larger, circular, and close together, the intervening reticulum so fine that only toward the ends of the shell, especially in front, are the spirals wide enough to show flattening. The result of these differences is that while nobilis on a casual glance looks almost smooth, the present species has a roughly punctate appearance. Longitude, 38 ; maximum latitude, $26 \mathrm{~mm}$. U.S. Nat. Mus. Cat. No. 9596.

Station 2127, United States Bureau of Fisheries, in 1,639 fathoms, greenish mud, south of Cuba. This shell was referred to as $S$. nobilis in my Blake report (pt. 2, p. 53), but under more careful microscopic scrutiny appears to be distinct. The single specimen is dead but well preserved.

\section{Family DIAPHANIDAE}

\section{Genus DIAPHANA Brown}

DIAPHANA FLORIDANA, new species

Shell small, inflated, thin, whitish, with an involved spire; surface smooth except for more or less conspicuous incremental lines; apex a small dimple, the posterior commissure of the aperture narrowly rounded, the anterior part expanded, rounded in front, the thin lip passing insensibly into the strongly thickened pillar-lip, with a conspicuous coating of enamel on the body. Length, 4; diameter, 3.5 mm. U. S. Nat. Mus. Cat. No. 107932.

Off Fernandina, a single specimen.

The form is slightly pyriform.

\section{Family PHILINIDAE}

\section{Genus PHILINE Ascanius}

PHILINE LUCIDA, new species

Shell minute, translucent white, flattish, of about two whorls, the apex depressed, minute, with a deep suture; the posterior commissure of the aperture rising roundly above the spire; surface finely spirally grooved, the grooves microscopically punctate; general outline of the depressed, last whorl ovate, the test very thin, the margin simple, the arch of the posterior commissure about equal to the curve of the spire opposite; the pillar lip slightly thickened and reflected, a thin 
layer of enamel over the body; interior smooth, except for a delicate rib emerging from the spire and extending about half way to the outer lip. Height, 3.5 ; breadth, 2 ; convexity, $1.2 \mathrm{~mm}$. U. S. Nat. Mus. Cat. No. 107933.

Off Fernandina, one specimen.

There is an ill-defined shallow constriction on the posterior part of the whorl, but this may be pathological.

\section{Family TURRITIDAE}

The members of this family in the collection are numerous but all small and white or translucent. Owing to the fact that their anatomy is unknown and even the presence or absence of an operculum can not be determined, the generic names used in this paper are merely tentative. The nomenclature of the group is so unsettled and in nearly all cases based merely on the shell characters, that no final arrangement is at present possible.

There have been several attempts at classification by nuclear characters, and in some minor groups they may be useful. I have elsewhere $^{2}$ given my reasons for considering that the nucleus in general has no fundamental generic importance, but that its characters are adaptive, either to a swimming larval stage or one that is relatively sedentary; with minor differences due to development in shallow or deep water. There is no doubt that an abyssal habitat tends to promote a smooth swollen or even mammillary protoconch and gyrate pillar with a pervious axis. These characters are probably related to the pressure of the deep sea environment.

\section{SPECIES WITH SWIMMING LARVAL STAGE AND SINUSIGERA NUCleUS}

\section{DA PHNELLA ? HYPERLISSA Dall}

Daphnella sofia, var. hyperlissa Dall, Bull. Mus. Comp. Zoöl., vol. 18, No. 29 pt. 2, 108, June, 1889.

Two immature specimens off Fernandina. Also off Cape Fear, North Carolina, at station 2678, in 731 fathoms, ooze, bottom temperature $39.8^{\circ} \mathrm{F}$.; United States Bureau of Fisheries.

\section{GYMNOBELA IMITATOR, new species}

Shell minute, white, with a Sinusigera nucleus of two and a half, and nearly four subsequent whorls; suture distinct, appressed; whorls only moderately convex; axial sculpture of (on the last whorl about 14) narrow, oblique ribs with wider interspaces, crossing the whorls, stronger on the earlier whorls, and ending in small close beadlike pustules in front of the suture; these ribs become obsolete on the base; spiral sculpture of a single carina near the periphery of the whorls, prominent where it intersects the ribs, and 10 or 12 fine threads in 
front of the carina which slightly cut the ribs in crossing them; anal fasciole wide, extending from the carina to the coronation of the suture; base moderately convex, pillar short, smooth, obliquely truncate; outer lip thin, sharp; canal wide and short. Length, 3 ; diameter, $1.5 \mathrm{~mm}$. U. S. Nat. Mus. Cat. No. 107958.

One specimen off Fernandina.

\section{GYMNOBELA? ILLICITA, new species}

Shell minute, white, with a brown Sinusigera nucleus of two and a half and four subsequent whorls; spire acute, suture appressed, somewhat constricted; anal fasciole rather wide, crossed by retractively concave wrinkles; axial sculpture of about 10 prominent ribs, wider and slightly angulate at the periphery, varying in number in different. specimens, up to 12 , and extending nearly across the whorls, but obsolete on the base and on the anal fasciole; spiral sculpture of two or three prominent threads near the periphery, over riding the ribs and half a dozen smaller ones on the base; base moderately convex, aperture subovate, the outer lip thin and protractively arcuate; pillar straight, obliquely truncate in front; canal rather wide, slightly recurved. Length, 3.5; diameter, $1.2 \mathrm{~mm}$. U. S. Nat. Mus. Cat. No. 107942 .

Five specimens off Fernandina.

GYMNOBELA? LANCEATA, ncw species

Shell minute, white, acute, with a Sinusigera nucleus of four and two subsequent whorls; suture appressed, bordered in front by close, short, axial wrinkles; anal fasciole slightly concave, wide, extending to the angle at the shoulder; axial sculpture of about 15 low, short oblique ribs most prominent at the shoulder, with wider interspaces and obsolete in front of the periphery; spiral sculpture of faint spiral striations visible only under the lens; aperture subovate, canal long, narrow, straight, pillar straight, attenuated in front. Length, 3 ; diameter, $1.5 \mathrm{~mm}$. U. S. Nat. Mus. Cat. No. 107962.

One specimen off Fernandina, perhaps immature.

\section{GYMNOBELA? GRUNDIFERA, new species}

Shell small, biconic, white, with a brown rounded Sinusigera nucleus of three and three subsequent whorls; suture appressed, minutely crenulated by the ends of the axial sculpture in front of it; anal sulcus wide and only moderately deep; the fasciole wide, sculptured with retractively arcuate, sharp, elevated lines; other axial sculpture of well marked incremental lines, and faint narrow indications of obsolete ribbing; spiral sculpture of a single strong peripheral keel, about eight slender low threads with wider interspaces in front of it, minutely crenulate by the axial sculpture, and much closer fine threading on the canal; base moderately rounded; pillar straight, attenuated in 
front; canal short, wide, outer lip thin, arcuate. Length, 5.2 ; diameter, $3.3 \mathrm{~mm}$. U. S. Nat. Mus. Cat. No. 107945.

Five specimens off Fernandina.

Probably immature but quite characteristic.

MANGILIA? IPARA Dall

Pleurotoma (Mangilia) ipara DALL, Bull. Mus. Comp. Zoöl., vol. 9, p. 57, Aug., 1881; vol. 18, No. 29, pt. 2, p. 115, pl. 11, fig. 14, June, 1889.

Two young specimens off Fernandina. Also from the Yucatan Strait in 640 fathoms and near Martinique in 502 fathoms.

This species may belong to the genus Gymnobela.

MANGILIA? SERICIFILA, new species

Shell minute, pale buff, with a brown Sinusigera nucleus of three and four subsequent well rounded whorls; suture appressed with a fine thread in front of it; anal sulcus wide and shallow, leaving a wide fasciole, arcuately striated behind it; in front of the fasciole there is an obscure shoulder to the whorl; axial sculpture of incremental lines, most conspicuous on the fasciole, and a double row of obscure undulations at the periphery, most marked on the earlier whorls; spiral sculpture of 10 or 12 equal, small threads in front of the periphery with narrow interspaces; base evenly rounded, canal short, wide; the pillar straight, attenuated in front; aperture ovate, the outer lip thin, arcuate. Length, 4; diameter $1.5 \mathrm{~mm}$. U. S. Nat. Mus. Cat. No. 108302.

One specimen off Georgia.

A variety from the same locality has the peripheral undulations absent and evenly rounded and spirally sculptured whorls, giving somewhat the aspect of an Astyris.

MANGILIA (SERICIFILA, var.?) STRONGYLA, new

Shell resembling sericifila in size and general aspect, but with the whorls evenly rounded and covered with spiral sculpture of equal and equally distributed close set small threads. The axis is minutely pervious. U. S. Nat. Mus. Cat. No. 107943.

One specimen off Georgia, and a dozen off Fernandina.

PLEUROTOMELLA? STEARINA, new species

Shell small (immature?), thin, of a greasy translucent white, with a brown Sinusigera nucleus of three, and three subsequent, rapidly enlarging whorls; suture appressed with gathered axial wrinkles in front of it; anal sulcus shallow and wide, distally rounded, the fasciole wide, slightly constricted, arcuately striated; axial sculpture of from 12 to 15 short, rounded, obliquely arcuate ribs with subequal interspaces, confined to the region between the fasciole and the periphery of the whorl; the lines of growth are obscure; spiral sculpture 
on the earlier whorls of an obscure shoulder in front of the fasciole, and over the whole shell fine even spiral striae, with flattish wider interspaces which on the canal become threadlike; aperture rather narrow, pillar straight, attenuated in front, outer lip thin and arcuate. Length, 5.6; diameter, 2.5 mm. U. S. Nat. Mus. Cat. No. 1083100.

Three specimens, off Georgia.

\section{PLEUROTOMELLA? CORRIDA, new species}

Shell minute, white, with a small Sinusigera nucleus of three, and four and a half subsequent well rounded whorls, suture appressed and constricted; anal sulcus deep, the fasciole narrow and close to the suture; axial sculpture of 11 prominent rounded ribs with wider interspaces, crossing the whorls from the fasciole nearly to the pillar; spiral sculpture of 4 or 5 fine, sharp threads with wide interspaces, a little swollen where they cross the ribs, and finer threadlets in the interspaces and on the base; base well rounded, pillar short, straight, gyrate with pervious axis; canal short; outer lip arcuately produced, thin, sharp. Length, 4.7; diameter, $2.0 \mathrm{~mm}$. U. S. Nat. Mus. Cat. No. 107947.

Two specimens off Fernandina and one off Georgia.

\section{PLEUROTOMELLA? (EUCYCLOTOMA) APERTA, new species}

Shell small (immature), white, thin, with a brown Sinusigera nucleus of three and two subsequent rapidly enlarging whorls; suture distinct, not appressed; anal sulcus wide and shallow, the fasciole flattish, with arcuate axial sculpture; spiral sculpture on the first normal whorl of a prominent peripheral keel and a second which is covered by the suture; on the second whorl there are two such crenulate keels one on each side of the periphery, with a wide interspace and and three less prominent on the base; axial sculpture of incremental lines which are periodically stronger; there are also half a dozen fine threads on the canal; base only moderately rounded, canal short, wide; pillar straight, attenuated anteriorly, gyrate, with a pervious axis; outer lip thin, the aperture very wide. Length, 4.5 ; diameter, $2.8 \mathrm{~mm}$. U. S. Nat. Mus. Cat. No. 108306,

One specimen off Georgia.

Though doubtless immature the characters of the species are so emphatic that it can not fail to be identified.

\section{EUBELA LIMACINA Dall}

Pleurotoma (Bela) limacina Dall, Bull. Mus. Comp. Zoöl., vol. 9, p. 55, Aug. 1881.

Daphnella limacina DALL, Bull. Mus. Comp. Zoöl.. vol. 9, p. 102, Oct., 1881.

Pleurotoma (Defrancia) hormophora Watson, Linn. Soc. Journ., vol. 15, p. 457, Nov. 3, 1881.

Clathurella hormophora WATson, Challenger Gastropods, p. 351, pl. 21, fig. 9,1885 . 
Daphnella limacina Verrill, Trans. Conn. Acad., vol. 5, p. 452, 1882; vol. 6, p. 265, 1884.

Daphnella (Eubela) limacina Dall, Bull. Mus. Comp. Zoöl., vol. 18, p. 106, pl. 9, fig. 10, June, 1889; U. S. Nat. Mus. Bull. 37, p. 100, pl. 9, fig. 10, 1889 .

Six specimens off Fernandina. Also in deep water from off Marthas Vineyard, Mass., to the South Atlantic off Pernambuco, Brazil, in from 85 to 805 fathoms.

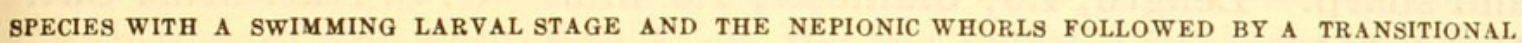
ARCUATELY RIBBED WHORL

\section{MANGILIA (TURRIDRUPA) COMATOTROPIS Dall}

Pleurotoma (Mangilia) comatotropis DALL, Mus. Comp. Zoöl., vol. 9, p. 58, Aug. 1881.

Pleurotoma (Mangilia) tiara WAtson, Linn. Soc. Journ., vol 10, p. 440, Oct., 1881; Challenger Gastropods, p. 347, pl. 21, fig. 7, 1885.

Pleurotoma comatotropis Verrill, Trans. Conn. Acad., vol. 5, p. 452.

Taranis pulchella Verrill, Trans. Conn. Acad., vol. 5, p. 487, pl. 57, fig. 17 (young) June, 1882; vol. 6, p. 267, pl. 29, fig. 8, 1884.

Mangilia comatotropis DaLL, Bull. Mus. Comp. Zoöl., vol. 18 p. 116, pl. 11, fig. 12, 1889; Bull. 37, U. S. Nat. Mus., p. 102, pl. 11, fig. 12, 1889.

Numerous specimens off Georgia and Fernandina.

This has the general form of Asthenotoma cicatrigula Hedley, and the nucleus of Turridrupa pertinax Hedley, both Australian forms.

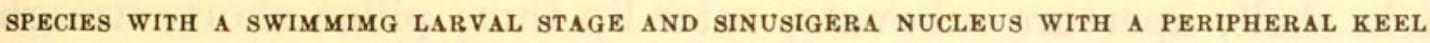

\section{PLEUROTOMELLA? LINEOLA, new species}

Shell small, thin, white, with a Sinusigera nucleus of two and a half brown whorls and three and a half subsequent well rounded whorls; suture closely appressed, somewhat constricted; anal sulcus deep and wide, the fasciole close to the suture, crossed by retractively arcuate wrinkles; axial sculpture of about 16 very narrow sharp ribs, with much wider interspaces, completely crossing the whorls except the anal fasciole; spiral sculpture of (on the last whorl 6) slender threads with much wider interspaces, so that the interstices of the reticulation are nearly square; the canal is finely spirally threaded; pillar short, straight, attenuate in front, gyrate, with pervious axis; aperture narrow, outer lip thin, arcuately produced in front. Length, 5.5; diameter, $2.25 \mathrm{~mm}$. U. S. Nat. Mus. Cat. No. 333529.

Three specimens off Fernandina.

This species has nucleus markedly spirally unicarinate, while in most of the species with the Sinusigera nucleus the whorls are rounded.

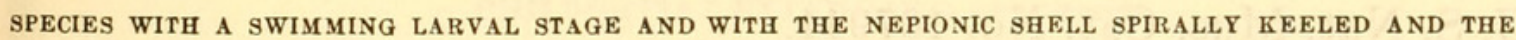
AXIAL SCULPTURE STRONG

MANGILIA ISCHNA, new species

Shell minute, glassy white, slender, acute, with a four-whorled brown nucleus in which the nepionic part is prominently peripherally 
keeled and the axial lines of the reticulum are prominent; the whole is followed by two or more translucent whorls on which the keels gradually disappear; suture distinct, not appressed; anal sulcus shallow, the fasciole indistinct; spiral sculpture of faint sparse spiral striae only visible under magnification; axial sculpture practically none; last whorl evenly rounded, with a long twisted, straight pillar, with a minutely pervious axis; aperture narrow, outer lip thin and sharp. Length, 4.6; diameter, $1.3 \mathrm{~mm}$. U. S. Nat. Mus. Cat. No. 107950.

One specimen off Fernandina.

\section{PLEUROTOMELLA? VAGINATA, new species.}

Shell small, whitish, subtabulate, with a small brownish nucleus of two whorls, the nepionic part of which is unicarinate and the axial threads prominent, followed by four well rounded, 'strongly sculptured whorls; suture distinct, constricted; anal sulcus deep but narrow, the fasciole narrow and close to the suture, somewhat excavated behind a prominent shoulder, giving a tabulate aspect to the whorls; axial sculpture of (on the last whorl 11) rounded somewhat flexuous ribs with much wider interspaces, the incremental lines obscure; spiral sculpture of numerous equal fine threads, sometimes alternated in size and sometimes not; but in general covering more or less closely the whole shell; aperture subovate, outer lip thin; pillar short, straight with a previous axis. Length, 5.3 ; diameter, $2.3 \mathrm{~mm}$. U. S. Nat. Mus. Cat. No. 108305.

Off Georgia, nine specimens.

SPECIES WITH A SWIMMING LARVAL STAGE, THE NUCLEAR AXIALS OBSOLETE AND A CARINA EMPHASIZED

\section{MANGILIA ACROCARINATA, new species}

Shell small, acute, pale brown when fresh, with a short sharply unicarinate nucleus of two, and six subsequent whorls; suture distinct, appressed; anal sulcus shallow and rounded, the fasciole extending between the suture and the shoulder of the whorl, flattish and smooth except for incremental lines; axial sculpture of (on the last whorl 10) extremely short ribs which appear chiefly as pointed nodules on a peripheral minute keel and again as faint pustules on a thread near the margin of the base; with wider interspaces; spiral sculpture of the above mentioned thread and keel, and a few fine close threads on the short canal; the general surface of the shell is polished with a waxy luster; base flattish; aperture ovate, short; canal wide, pillar attenuated in front, axis impervious. Length, 6.5; diameter, $2.7 \mathrm{~mm}$. U. S. Nat. Mus. Cat. No. 107944.

Twenty specimens off Fernandina. 
SPECIES With A SEDENTARY LARVAL STAGE AND A SMOOTH INFLATED WHITE NUCleUs OF FEW WHORIS

PHILBERTIA ? PERDECORATA, new species

Shell small, translucent white, strongly sculptured, with a nucleus of a whorl and a half and five and a half subsequent whorls; suture distinct, appressed; axial sculpture of (on the last whorl 10, beside the apertural varix) rounded equal ribs with wider interspaces, crossing the whorls but obsolete more or less on the last nalf of the last whorl behind the varix; the incremental lines inconspicuous; spiral sculpture of (on the spire 3, on the last whorl 4 behind the suture, and about 16 on the base and canal) sharp threads with subequal interspaces, over riding the ribs; base rounded, canal very short; aperture small, ovate, the outer lip heavily varicose with a thin inflected edge; the anal sulcus large, shallow, and rounded, leaving a very feeble fasciole; the inner lip and body callous, the canal short and wide. Length, 8.5; diameter, $4.3 \mathrm{~mm}$. U. S. Nat. Mus. Cat. No. 108291. The short one is $7 \mathrm{~mm}$. long.

Off Georgia, very common, perhaps the most numerous species of the collection, but mostly blackened by manganese.

The outer lip is so generally defective or immature that I am able to find only one specimen complete out of the whole series, and that one happens to be a whorl shorter than the average specimen.

None was found off Fernandina.

\section{PHILBETIA PERDECORATA, variety? LIONTA, new}

Shell small, slender, elongate, white, with a nuclear apex of two and five subsequent whorls; suture distinct, appressed; the anal sulcus very shallow, the fasciole hardly depressed, obscure, axially wrinkled near the suture; whorls moderately rounded; axial sculpture of (on the penultimate whorl 16) narrow straight ribs with wider interspaces, crossing the whorls on the spire but obsolete or entirely absent over the greater part of the last whorl, which ends in mature specimens with a strong varix; incremental lines feeble; spiral sculpture as in perdecorata but less emphatic, the threads on the spire crenulating the summits of the ribs slightly; mature aperture much as in perdecorata. Length, 11; diameter, 4 mm. U. S. Nat. Mus. Cat. No. 333445.

Eighteen specimens off Fernandina and three or more off Georgia.

This differs from perdecorata in its less emphatic ribs and more feeble sculpture, more numerous ribs, and somewhat more slender form; it seems to take the place of perdecorata in the material collected off Fernandina. However, there are some intermediate specimens.

PHilbertia? EXtenuATA, new species

Shell small, slender, whitish, with a smooth nucleus of a whorl and a half and six subsequent moderately rounded whorls; suture distinct, $24105-27 \dagger-3$ 
not appressed; axial sculpture of (on the penultimate whorl about 18) protractively oblique narrow close set equal ribs crossing the whorls on the spire, obsolete on the base and pillar; incremental lines feeble; spiral sculpture of faint obscure threads between the ribs, and two sharp grooves at the margin of the base, which seem to duplicate the suture when one of them is exposed; the base is free from ribs but behind the aperture is a well defined hump or varix; outer lip produced in front, the anal sulcus shallow leaving an illdefined fasciole, aperture narrow, canal short and wide. Length, 11; diameter, $4 \mathrm{~mm}$. U. S. Nat. Mus. Cat. No. 108298.

Off Georgia, a dozen worn specimens.

\section{CLATH RODRILLIA INIMICA, new species}

Shell minute, white, with a smooth nucleus of one and a half to two whorls, and five subsequent prominently sculptured whorls; suture distinct, appressed; the edge in front thickened and undulated by the sculpture, the anal sulcus shallow but the fasciole constricted and nearly smooth; axial sculpture of (on the last whorl 16) narrow, nearly straight rounded ribs with subequal or narrower interspaces, crossing the whorls from a slight shoulder in front of the anal fasciole to the succeeding suture and becoming gradually obsolete on the base; the incremental lines are well marked; spiral sculpture on the second normal whorl 3 , on the next 4 , and on the last whorl 10 slender threads with wider interspaces, overrunning the ribs and in front of these finer close-set threads on the pillar; aperture hardly wider than the canal, the outer lip thin, arcuately produced in front, pillar very short, attenuated in front. Length, 6.6 ; diameter, $3 \mathrm{~mm}$. U.S. Nat. Mus. Cat. No. 108292.

Off Georgia, about 25 specimens.

This has the general aspect of $P$. perdecorata but is smaller, with a more constricted fasciole and more numerous spirals. It also wants the varicose and inflected outer lip.

\section{CLATHRODRILLIA ORELLANA, new species}

Shell small, slender, whitish, with a smooth nucleus of one and a half, and four and a half subsequent whorls; suture distinct, not constricted or appressed; anal sulcus wide and shallow, the fasciole not excavated, inconspicuous; axial sculpture of protractively flexuous incremental lines, stronger near the apex, and in some cases feeble narrow ribs are developed on the earlier whorls, with wider interspaces; spiral sculpture of very fine threads, equal and with subequal interspaces, though a little coarser on the well-rounded base; aperture slightly wider than the canal, the outer lip thin, flexuous, sometimes a feeble thickening behind it; the whorls are usually rounded but sometimes there is a slight shoulder in front of the fasciole; pillar 
short, attenuated in front, canal short and wide. Length, 7.4; diameter, $3.5 \mathrm{~mm}$. U. S. Nat. Mus. Cat. No. 108293.

Off Georgia, six specimens.

The sculpture varies in strength with the individual, the form taken as typical is practically without ribs.

\section{CLATHRODRILLA DOLANA, new species}

Shell small, whitish, with a smooth nucleus of a whorl and a half, and five subsequent moderately rounded whorls; suture distinct, hardly appressed, the anal fasciole nearly smooth, hardly concave; axial sculpture of (on the last whorl about 16, exclusive of the varix) narrow, small, very flexuous ribs, sometimes a little angular in front of the fasciole, with equal or narrower interspaces obsolete on the base; spiral sculpture of (between the sutures 3) fine conspicuous threads with wider interspaces, overriding the ribs; on the base and canal about 10 more diminishing forward; aperture little wider than the canal; anal sulcus shallow, rounded, outer lip thin, not inflected, protractively flexuous; pillar short, attenuated in front; canal short, wide. Length, 6.5; diameter, $2.5 \mathrm{~mm}$. U. S. Nat. Mus. Cat. No. 107934 .

Numerous specimens from off Fernandina.

CLATHRODRILLIA? FANOA, new species

Shell small, white, strongly sculptured, the aperture shorter than the spire; with a smooth protoconch of a whorl and a half, and half a whorl of transitional thin sharp axial riblets before the latter assume the adult characters on the four subsequent whorls; suture appressed, the fasciole in front of it narrow and obscure; whorls well rounded; axial sculpture of 13-14 rounded ribs (on the last whorl) with wider interspaces, crossing the whorls on the spire, obsolete on the base; incremental lines not conspicuous; spiral sculpture of three strong cords, overriding the ribs; and about a dozen smaller plain threads on the base and canal; aperture rather narrow, anal sulcus very shallow, outer lip sharp, protractively arcuate, thin; pillar straight, somewhat gyrate but with an impervious axis; attenuated in front; canal rather long and wide. Length, 7 ; diameter, $3.1 \mathrm{~mm}$. U. S. Nat. Mus. Cat. No. 107957.

Off Fernandina, five specimens.

\section{SUAVODRILLIA? TEXTILIA, new species}

Shell small, vitreous white, with an inflated smooth nucleus of two and four subsequent whorls; suture distinct, not constricted or appressed, the fasciole in front of it conspicuous; axial sculpture of well-marked incremental lines and (on the last whorl about a dozen) protractively flexuous ribs with equal or wider interspaces, these are 
well marked on the spire where they cross the whorls, slightly shouldered in front of the fasciole, but less well defined on the last whorl and obsolete on the base; there is also a varical swelling behind the outer lip in the mature shell; spiral sculpture of almost invisible minute striae covering the whole surface; aperture ovate, the outer lip thickened and inflected, the anal sulcus wide and shallow; pillar short, canal very short and wide; the last whorl more than half as long as the shell. Length, 8 ; diameter, $2.7 \mathrm{~mm}$. U. S. Nat. Mus. Cat. No. 333449.

One off Fernandina, seven off Georgia.

DAPHNELLA? SAGENA, new species

Shell small, vitreous white, few whorled, the last whorl much the largest; with a smooth nucleus of a whorl and a half and somewhat more than three and a half subsequent whorls; suture inconspicuous, not constricted, the fasciole feebly marked; axial sculpture of (on the last whorl about a dozen) low rounded ribs with much wider interspaces, crossing the whorls, and well-marked close incremental lines; spiral sculpture of (on the first adult whorl 2, on the next 3 , and on the last whorl 8 or 9) sharp fine threads with much wider interspaces, a little swollen where they override the ribs, and forming by the intersection a rather open reticulum; in the interspaces are very fine close spiral striae; this sculpture covers the shell; aperture narrow, hardly wider than the canal, the anal sulcus very shallow, the outer lip hardly thickened; pillar short and straight, axis impervious. Length, 5 ; diameter, $2.2 \mathrm{~mm}$. U. S. Nat. Mus. Cat. No. 108311.

Two specimens off Georgia, 28 off Fernandina. A single specimen more slender than the others is otherwise identical.

DAPHNELLA? EPOMIS, new species

Shell minute, white. slender, with a small smooth nucleus of about one whorl, and three subsequent whorls; suture distinct, not appressed, the fasciole in front of it flattish, the anterior margin of the fasciole forming a more or less angular shoulder to the whorl; axial sculpture of very fine incremental lines and at and near the shoulder of feeble fine flexuous wrinkles, stronger on the spire; spiral sculpture of very fine close striae over the whole surface except a few threads on the canal; the last whorl equals about two-thirds the whole length; aperture narrow, the canal hardly differentiated, outer lip (immature?) thin and sharp, the anal sulcus obscure; pillar straight, attenuated in front, axis impervious. Length, 6.3 ; diameter, $2 \mathrm{~mm}$. U. S. Nat. Mus. Cat. No. 107966.

Off Fernandina, one specimen. 
MANGILIA ? CHASMATA, new species

Shell small, slender, white, the aperture about half the length, with a blunt smooth nucleus of a whorl and a half, and three and a half subsequent whorls; suture appressed and slightly coronated by the swollen ends of the ribs; the fasciole slightly constricted, its anterior edge forming an angular shoulder; axial sculpture of (on the last whorl about 20) narrow rather straight rounded ribs with equal or wider interspaces crossing the whorls, flexuous on the fasciole; spiral sculpture none, even the back of the canal is smooth; aperture narrow, the canal hardly differentiated, the anal sulcus wide and shallow, the pillar straight, attenuated in front, axis impervious. Length, 5.5; diameter, $2 \mathrm{~mm}$. U. S. Nat. Mus. Cat. No. 107964.

Off Fernandina, 20 specimens.

MANGILIA LASTICA, new species

Shell small, slender, whitish, the aperture about one-third the whole length, with a smooth nucleus of one and a half to two whorls and seven subsequent well rounded whorls; suture distinct, not appressed, the fasciole in front of it flattish and sloping; the sculpture varying in strength in different individuals; usually stronger on the earlier whorls; axial sculpture of numerous protractively oblique narrow ribs with subequal interspaces, flexuous but not prominent (as a rule) on the fasciole and absent from the base, the incremental lines inconspicuous; spiral sculpture of two equal threads just behind the suture, but not equally obvious in all the specimens, especially the young; in those with strong sculpture there are two or three more or less evident small threads overriding the ribs, but in all young cases the base is smooth, the ribs stopping abruptly; in the fully adult there may be a few obsolete spirals on the base, and a few evident ones on the canal; aperture subovate with a wide and short canal; outer lip protractively arcuate, the anal sinus shallow and wide; the pillar short, attenuated in front, axis impervious. Length, 11; diameter, $4 \mathrm{~mm}$. U. S. Nat. Mus. Cat. No. 107967.

Off Fernandina, 25 specimens.

A variety, with stronger sculpture has a short nucleus, and the spirals continuous over the base, the two near the suture less evident.

MANGILIA? TACHNODES, new species

Shell small, lucid white, slender, with a very short nuclear whorl and five and a half subsequent whorls; suture distinct, constricted, not appressed, the fasciole in front of it flattish, its anterior edge angular, forming a conspicuous shoulder to the whorls; axial sculpture of (on the last whorl about 25) threadlike ribs, stronger on the earlier whorls, with subequal interspaces, crossing from suture to 
suture, sharply nodulous at the shoulder and obsolete on the base; incremental lines inconspicuous; spiral sculpture of (on the spire three, on the last whorl six or seven, alternating in strength) sharp threads, prominently nodulous where they override the ribs; base and pillar smooth; aperture ovate, about one-fourth the whole length, canal hardly differentiated, pillar very short; outer lip sharp, anal sulcus wide and shallow. Length, 7.5; diameter, $2.2 \mathrm{~mm}$. U. S. Nat. Mus. Cat. No. 333446.

One specimen, off Fernandina.

The strong rather sharp sculpture gives this form a peculiarly elegant appearance.

MANGILIA ? CROSSATA, new species

Shell small, resembling a Lora in shape, white, biconic, the aperture more than half the total length, polished, with a very short smooth nuclear whorl and three subsequent whorls; suture distinct, appressed, coronated by the ends of the ribs; spire very short, whorls with a subangular shoulder; axial sculpture of (on the last whorl about a dozen) narrow elevated ribs with wider interspaces extending from the suture to the base where they become obsolete, minutely nodulous where they cross the angle at the shoulder; spiral sculpture of faint fine threading, on the canal and the anterior part of the base; aperture narrow, canal hardly differentiated, anal sulcus shallow; pillar straight, attenuated in front, outer lip thin, sharp, nearly straight, axis impervious. Length, 6 ; diameter, $3 \mathrm{~mm}$. U. S. Nat. Mus. Cat. No. 107959.

Six specimens, off Fernandina.

MANGILIA? CRYERA, new species

Shell much resembling $M$. crossata, but thinner, more glassy, averaging smaller, with no coronation at the suture, and with a faint pervasive spiral striation. Length, 5; diameter, $2.1 \mathrm{~mm}$. U. S. Nat. Mus. Cat. No. 107960.

Numerous both off Fernandina and Georgia.

This species, like most of these deep water gastropods varies in the strength of its sculpture, and a few specimens have the shoulder angle obsolete or completely rounded off.

MANGILIA ? CHRISTINA, new species

Shell small, thin, slender, lucid white, with a large swollen nucleus of a whorl and a half and nearly four subsequent whorls; suture distinct, not appressed or marginated; fasciole in front of it obscure but giving rise to a distinct shoulder not far from the suture; aperture about half the length of the shell; the whorls flattish; axial sculpture of (on the last whorl or a dozen) narrow, nearly straight ribs, with wider interspaces, obsolete on the base, but occasionally a little nod- 
ulous at the shoulder; spiral sculpture hardly discernable or none, even on the canal; aperture narrow, anal sulcus feeble, canal hardly differentiated; outer lip straight, thin and sharp; pillar straight attenuated in front, axis impervious. Length, 6.5 ; diameter, $2 \mathrm{~mm}$. U. S. Nat. Mus. Cat. No. 107937.

Abundant off Fernandina.

\section{MANGILIA FRITILLARIA, new species}

Shell small, slender, white, with a smooth nucleus of a whorl and a half and three and a half subsequent whorls; suture distinct, appressed, coronated by the ends of the ribs in front, the fasciole sloping, hardly constricted; axial sculpture of (on the last whorl about a dozen) narrow nearly straight ribs, with wider interspaces, strongest at the shoulder, obsolete on the base and toward the end of the last whorl; spiral sculpture of (on the last whorl about 14) obsolete, close set, hardly perceptible equal and equally distributed small threads covering the whorl in front of the shoulder; aperture narrow, about two-fifths the whole length, anal sulcus feeble, canal hardly differentiated; pillar straight, attenuated in front, axis impervious. Length, 6; diameter, 2 mm. U. S. Nat. Mus. Cat. No. 107968.

One specimen off Fernandina.

This belongs to the same group as $M$. christina, differing in details of sculpture. Until we know the range of variation in these deepsea species it seems most convenient to treat marked differences as specific. The whorls in this species are only moderately rounded and distinctly angular at the shoulder.

\section{MANGILIA？ SUBCIRCULARIS, new specics}

Shell small, slender, thin, with a blunt apex, whitish, glistening; with a swollen nucleus of a whorl and a half and four and a half subsequent well rounded whorls; suture distinct, appressed, with a smooth, hardly constricted fasciole in front of it; axial sculpture chiefly of rather strong flexuous incremental lines and a few gradually obsolescent riblets on the earlier whorls; spiral sculpture of (on the last whorl 18-20) fine prominent threads rising above the incremental lines, with wider interspaces, covering the whole whorl in front of the fasciole; aperture ovate, about one-third the whole length, the anal sulcus forming nearly a semicircle, the outer lip thin and arcuate, canal wide; pillar twisted, attenuated in front; axis impervious. Length, 8.0 ; diameter, $2.7 \mathrm{~mm}$. U. S. Nat. Mus. Cat. No. 333450 .

Two specimens off Georgia.

The thin, glistening shell and rotund whorls are its conspicuous characters. 
MANGILIA ? PERCOMPACTA, new species

Shell minute, solid, whitish, the nucleus lost, but three and a half subsequent whorls remain; suture distinct, constricted, with a fringe of minute axial wrinkles on the fasciole in front of it; there is no other axial sculpture except faint incremental lines; spiral siculpture of (on the last whorl about 10) fine, equal and equally distributed low threads with narrower interspaces, covering the whole shell except the anal fasciole; aperture ample, hardly differentiated from the short canal; anal sulcus wide and rather deep; outer lip prominently arcuate; pillar short, twisted, strong; axis minutely pervious. Length, 2.3 ; diameter, $1.3 \mathrm{~mm}$. U. S. Nat. Mus. Cat. No. 108301.

One specimen off Georgia.

This is perhaps not a Mangilia but may be tentatively placed here in the absence of a knowledge of the animal. The only other species which approaches it in form which I have been able to discover is the much larger "Daphnella" nana Lovèn.

\section{MANGILIA? ACLONETA Dall}

Drillia(? dalli Verrill, var.) acloneta DALL, Bull. Mus. Comp. Zoöl., vol. 18, p. 92, June, 1889.

This is much smaller when adult than the typical dalli. It occurs abundantly at both stations 2415 and 2668, and was also obtained off Martinique, in 170 fathoms.

The typical acloneta is smooth, but has occasionally a slight angle at the shoulder and a few obscure riblets on the earlier whorls. U. S. Nat. Mus. Cat. No. 87332 .

Another form which is probably an extreme variety of acloneta, has a strong shoulder angle, the obsolete ribbing is carried on over all the whorls and the base is spirally threaded. This was named at the same time as acloneta, variety cestrota. A single specimen was obtained off Fernandina; U. S. Nat. Mus. Cat. No. 107935.

Variety cestrota was also obtained at station 2399, in 196 fathoms, mud, temperature $51.6^{\circ}$, in the Gulf of Mexico, between the delta of the Mississippi and Cedar Keys, Florida, by the U. S. S. Blake.

MANGILIA? CRATERA, new species

Shell small, white, solid, nearly smooth with a large smooth nucleus of about two whorls and four and a half subsequent whorls; suture distinct, not appressed, the fasciole in front of it obscure, not constricted; the only sculpture on typical specimens consists of feeble incremental lines; there are faint indications of ribbing on some of the worn specimens which may belong to this species; whorls well rounded and rather rapidly increasing in diameter; aperture ample, anal sulcus wide and shallow; outer lip slightly thickened and inflected; canal wide, hardly differentiated; pillar short and strong, the axis impervious. Length, 8.5; diameter, 4 mm. U. S. Nat. Mus. Cat. No. 107946. 
Fifteen specimens and fragments off Fernandina; one fragment off Georgia.

This is of the same general type as $M$. acloneta, but the whorls increase in size much more rapidly.

MANGILIA? AREIA, new species

Shell small, white, with a swollen nucleus of a whorl and a half and nearly four subsequent whorls; suture distinct, appressed, constricted, with a conspicuous line of pustules in front of it, the fasciole very narrow and obscure, the whorl in front of it with a rounded shoulder; axial sculpture of (on the last whorl about a dozen) straight, narrow ribs, prominent at the shoulder, obsolete on the base, and with wider interspaces; the incremental lines are inconspicuous; spiral sculpture of (on the penultimate whorl 5 or 6 ) low threads slightly corrugating the summits of the ribs; on the last whorl in the adult they extend from the shoulder to the canal, where they are somewhat coarser; aperture sublunate, hardly differentiated from the canal; anal sulcus very feeble, outer lip thin, canal straight, attenuated in front, the axis impervious. Length, 8; diameter, 3 mm. U.S. Nat. Mus. Cat. No. 107954.

Two specimens and some fragments from off Fernandina.

The specimen may not be entirely mature.

\section{MANGILIA? LORAEFORMIS, new species}

Shell short, small, polished, whitish, solid, with a large nucleus of a whorl and a half and three and a half subsequent whorls; suture distinct, not appressed, the fasciole inconspicuous, the whorls moderately rounded, the aperture about half the whole length; axial sculpture of more or less obscure folds, stronger on the early whorls, seldom differentiated into distinct ribs, sometimes forming a rounded shoulder to the whorls; beside these there are irregularly distributed incremental lines; there is no indication of any spiral sculpture; aperture narrow, the anal sulcus hardly evident, the outer lip straight, thin or very slightly thickened; pillar straight, axis not pervious. Length, 4.5; diameter, 2 mm. U. S. Nat. Mus. Cat. No. 108308.

Off Fernandina, about 30 specimens.

Except for its obsolete sculpture it bears the aspect of a Lora.

\section{MANGILIA? PELAGIA Dall}

Pleurotoma (Mangilia) pelagia DALL, Bull. Mus. Comp. Zoöl., vol. 9, p. 61 August, 1881.

Mangilia pelagia DALL, Bull. Mus. Comp. Zoöl., vol. 18, p. 117, pl. 11, fig. 9, June, 1889.

One specimen off Georgia. Also at Blake station 44, in 539 fathoms, in the Gulf of Mexico, bottom temperature $39.5^{\circ} \mathrm{F}$.

$$
24105-27 \dagger-4
$$


MANGILIA? RHABDEA, new species

Shell white, with a smooth nucleus of about one whorl and three subsequent nearly cylindrical whorls; suture distinct, not appressed, anal fasciole faintly indicated; axial sculpture only of obscure incremental lines; spiral sculpture of on the last whorl only, a faint suggestion of an angle at the shoulder; aperture narrow, about two-fifths as long as the shell; outer lip thin, protractively arcuate; anal sulcus wide and deep; pillar straight, canal hardly differentiated. Length, 4.5; diameter, $1.5 \mathrm{~mm}$. U. S. Nat. Mus. Cat. No. 107949.

One specimen, off Fernandina.

Although the specimen is defective and possibly immature, the characters are so distinctive that it can not fail to be recognized.

\section{CYMATOSYRINX EBUR, new species}

Shell small, white, solid, with a swollen nucleus of a whorl and a half and five and a half subsequent whorls; suture distinct, not appressed, with a slightly constricted fasciole in front of it; axial sculpture of (on the last whorl 10-11) rounded flexuous smooth ribs, most prominent at the periphery on the spire, sigmoidly flexed on the last whorl and absent from the base; the interspaces are equal or wider than the ribs; there is no spiral sculpture; the aperture is wide, less than a third of the whole length, the anal sulcus wide and deep, the outer lip very prominently protractively arcuate, the pillar short, the canal short and wide, the axis not pervious. Length, 8; diameter, $3.2 \mathrm{~mm}$. U. S. Nat. Mus. Cat. No. 107948.

Off Fernandina, about 20 specimens.

There are several other species of this family represented by young or fragmentary specimens too imperfect to serve for a satisfactory diagnosis.

\section{Family CANCELLARIIDAE}

\section{Genus ADMETE Kroyer}

\section{Section MICROCANCILLA Dall, 1924}

\section{ADMETE MICROSCOPICA Dall}

Cancellaria? microscopica DALL, Bull. Mus. Comp. Zoöl.,vol 18, p. 131, 1889. Admete (Microcancilla) microscopica DALL, Proc. Biol. Soc. Wash., vol.37, p. 87, 1924.

Shell small, short, wide, white with a small, smooth, white blunt nucleus of a whorl and a half and about two and a half subsequent whorls; whorls convex, suture distinct, deep, with a marked shoulder in front of it; axial sculpture of (on the last whorl about 14) low rounded nearly vertical ribs with narrower interspaces, crossing the periphery, obsolete on the base; and very faint incremental lines; spiral sculpture of (on the last whorl about 9 ) equal and equally spaced slender threads with wider interspaces, reticulating but not nodulat- 
ing the axials; aperture subtriangular, the margin continuous, thin, smooth, the pillar lip reflected, with a narrow umbilicus in the adult but none in the young; the pillar shows no plaits, from in front none are visible; the anterior end of the aperture not channelled. Length of shell, 4; of aperture, 2; diameter, $2.5 \mathrm{~mm}$. U. S. Nat. Mus. Cat. No. 107987.

Off Georgia and Fernandina; also Campeche Bank and off Yucatan in 200 to 780 fathoms.

This exact position of this species in the family is doubtful; the plaits are generally absent at the aperture, and the internal pillar shows only one rather strong plait, yet in every other respect it agrees well with such species as $A$. couthouyi Jay.

\section{ADMETE NODOSA Verrill and Smith}

Admete nodosa Verrill and Smith, Trans. Conn. Acad., vol. 6, pt. 2, p. 419 , pl. 44, fig. 9, 1885 ,

Off Fernandina, three young shells probably of this species. Also off Nantucket and south of Long Island, New York, in 816 and 924 fathoms.

The shell has two well marked plaits.

\section{Family OLIVELLIDAE}

\section{Genus OLIVELLA Swainson}

\section{OLIVELLA TUBULATA Dall}

Olivella tubulata Dall, Bull. Mus. Comp. Zoöl., vol. 18, p. 136, 1889.

Off Fernandina, a fragment of this species was obtained.

\section{OLIVELLA BULLULA Reeve}

Olivella bullula Reeve, Conch. Icon., Oliva, pl. 30, fig. 96, 1850.

Off Fernandina, one juvenile specimen.

It was found by the Blake about Cuba, off Sombrero and St. Vincent, West Indies, in 72 to 464 fathoms.

\section{Family MARGINELLIDAE}

\section{Genus MARGINELLA Lamarck}

Subgenus Marginella s. s.

MARGINELLA FERNANDINAE, new species

Shell small, white, polished, anteriorly attenuated, with a blunt apex and about four and a half whorls, the aperture nearly as long as the shell; suture obscure, overlaid with enamel; aperture narrow, outer lip heavily thickened, with about 16 crenulations, varicose, with a marked channel behind it; there is no spiral sculpture; axial sculpture of more or less obvious incremental lines; body thinly glazed, with four subequal plaits, the anterior evenly rounded about a shallow 
sulcus, to the outer lip. Length of shell, 8.5; greatest diameter near the posterior fourth, $5.5 \mathrm{~mm}$. U. S. Nat. Mus. Cat. No. 107973.

Off Fernandina, numerous specimens.

MARGINELLA CANILLA, new species

Shell small, white, anteriorly attenuated, of about four whorls, the apex blunt, the suture appressed and only very slightly glazed over; spire short, the periphery of the last whorl quite posterior; aperture narrow, hardly wider in front; outer lip thickened, obscurely crenulate with a groove behind it, receding behind and in front; inner lip with four subequal and a posterior very feeble plait, the anterior edge of the pillar counted as a plait; canal deep, very short, with a thickened margin continuous with the outer lip. Length of shell, 10; of aperture, 8.5; diameter, $4.5 \mathrm{~mm}$. U. S. Nat. Mus. Cat. No. 108329.

Off Georgia and Fernandina, numerous specimens.

Viewed from above this species closely resembles $M$. fernandinae but from the opposite side it is seen to be narrower at the shoulder, with a higher spire, an additional plait, and less distinct denticulation of the outer lip.

\section{MARGINELLA OCELLA, new species}

Shell small, short, stout, translucent white, with a very short spire of about three and a half whorls, smoothly overglazed; axial sculpture of obsolescent incremental lines, surface polished; there is no spiral sculpture; aperture nearly as long as the shell, narrow, the outer lip nearly straight, thickened but not varicose nor crenulate; body and pillar not enamelled, bearing four subequal plaits, the anterior rounding evenly about a rather deep sinus to the outer lip; axis impervious. Length, 5.5; diameter, $3.5 \mathrm{~mm}$. U. S. Nat. Mus. Cat. No. 107977.

Off Fernandina, abundant.

MARGINELLA TANORA, new species

Shell minute, translucent white, blunt-tipped, with about three and a half whorls; suture distinct, narrowly appressed, and constricted, the anterior edge minutely axially wrinkled; whorls moderately convex, the spire not covered with a glaze; surface smooth, with faint obsolescent incremental lines; aperture more than half the length of the shell; outer lip slightly thickened, simple; inner lip with a thin glaze, pillar short with four subequal thin plaits, including the prominent anterior edge of the pillar. Length, 3.7; diameter, $2 \mathrm{~mm}$. U. S. Nat. Mus. Cat. No. 108331.

Off Georgia, 25 specimens.

MARGINELLA INCESSA, new species

Shell small, cone shaped, polished, creamy white, with a very blunt apex and about four and a half whorls; suture obscure, appressed, 
shallow, with an overglaze; whorls slightly convex; aperture ample, outer lip smooth, thin, not sharp edged, nearly straight, not varicose; pillar and border with a wash of enamel, the former with four subequal thin plaits, the anterior rounding into the onter lip with a very shallow sulcus. Length of shell, 5 ; of aperture, 4 ; diameter, 3.5 mm. U. S. Nat. Mus. Cat. No. 107976.

Off Fernandina, numerous specimens.

This is similiar to $M$. tanora but larger, slightly more slender, more delicate, and with a less heavy outer lip.

MARGINELLA INEPTA, new species

Shell small, thin, subcylindric, white, polished; the apex bluntly rounded-conical, of three whorls; aperture nearly as long as the shell, ample, the outer lip slightly thickened, simple, nearly straight; a narrow sinus behind, hardly any in front, the short pillar with three subequal plaits. Length of shell, 7; of aperture, 6 ; diameter, $4 \mathrm{~mm}$. U. S. Nat. Mus. Cat. No. 107974.

Off Georgia and Fernandina, not rare.

MARGINELLA IMMITATOR, new species

Shell minute, biconic, blunt, white, with about three and a half polished whorls; suture minutely appressed, not glazed over; aperture more than half as long as the shell, rather wide, outer lip thickened, varicose, receding behind aud before, not crenulate; pillar with four subequal plaits including that on its anterior edge which rounds evenly into the outer lip. Length of shell 2.6 ; of aperture, 1.6 ; diameter, $1.6 \mathrm{~mm}$. U. S. Nat. Mus. Cat. No. 108332.

Off Georgia, one specimen.

Much smaller, but like $M$. incessa in form.

MARGINELLA MICROGONIA, Dall

Marginella microgonia DalL, Bull. U. S. Nat. Mus. No. 37, 1889, p. 108 (name only).

Shell minute, short, stout, white, with a low spire coverd by an overglaze, the aperture shorter than the shell, subequally wide throughout its length, the outer lip smooth with no groove behind it, the pillar with four plaits; surface smooth except at the shoulder which carries 10 to 15 minute axial riblets. Length, 3; diameter, $2 \mathrm{~mm}$. U. S. Nat. Mus. Cat. No. 107975.

Off Georgia and Fernandina, abundant.

The diagnosis of this species was inadvertently overlooked in 1889 .

MARGINELLA ESTHER, new species

Shell small, elongate-ovate, polished, white, thin, with nearly four whorls and a very blunt apex; suture appressed, not deep, not glazed over; whorls only moderately convex; aperture ample, outer lip thin, 
not sharp, inner lip with a wash of enamel, pillar with four subequal thin plaits, the anterior end rounding evenly into the outer lip, with a rather deep anterior sinus. Length of shell, 5 ; of aperture, 3 ; diameter, $2.5 \mathrm{~mm}$. U. S. Nat. Mus. Cat. No. 107978 .

Off Fernandina, many specimens.

This has much the form of Conrad's $M$. denticulata (a preoccupied name subsequently replaced by eburneola Conrad) but only two-thirds the size, and with a blunter apex, while the outer lip is without denticulation.

\section{Genus HYALINA Schumacher}

HYALINA STYRIA Dall

Marginella styria DALL, Bull. Mus. Comp. Zoöl., vol. 18, p. 140, 1889; Trans. Wagner Inst., vol. 3, p. 54, pl. 5, fig. 1, 1890.

Shell small, smooth, polished, white, with a blunt apex and about four whorls; the suture appressed and overglazed smoothly; general form elongate-oval; aperture narrow, widest in front; outer lip straight, slightly thickened, inner lip with four nearly equal plaits counting the thickened edge of the end of the pillar, axis more or less pervious in different specimens. Length of shell, 7; of aperture, 4.5; diameter, $2.5 \mathrm{~mm}$. U. S. Nat. Mus. Cat. No. 107981.

Off Georgia and Fernandina, very abundant. Off Sombrero, U. S. S. Blake.

\section{HYALINA STYRIA (variety) MINOR Dall}

Shell small, smooth, polished, white, with a blunt apex and about four whorls; suture appressed and smoothly glazed over; the spire pointed with a small blunt nucleus; aperture narrow, slightly wider in front; outer lip narrow, straight, bent in, in front of a slight varix, pillar short, with three nearly equal plaits including the thickened anterior edge of the pillar; axis imperforate. Length of shell, 6 ; of aperture, 4; diameter, 2 mm. U. S. Nat. Mus. Cat. No. 107982.

Off Fernandina, numerous specimens.

Although very similar to the species regarded as $M$. styria s. s., these are uniformly smaller and very uniform in character.

\section{HYALINA TORTICULA ELUSIVA (new variety)}

Shell small, slender, elongate, smooth, polished, yellowish white, with a blunt apex and about four whorls; suture appressed and smoothly glazed over; aperture narrow; the outer lip slightly thickened but without a varix, the middle part moderately arcuately produced; the pillar with four equal plaits, counting the thickened anterior edge; axis impervious. Length of shell, 10; of aperture, 6; diameter, $4 \mathrm{~mm}$. U. S. Nat. Mus. Cat. No. 107980.

Off Fernandina, many specimens. 
These specimens differ from typical torticula in being smaller, apparently more slender, and having the torsion much less evident, but there seems to be some intergradation.

\section{HYALINA (variety?) AVENELLA Dall}

Marginella (avena variety ?) avenella DALL, Bull. Mus. Comp. Zoöl., vol. 9, p. $73,1881$.

Marginella succinea (Conrad) DaLL, Bull. Mus. Comp. Zoöl., vol. 18, p. 189, pl. 19, fig. 6, 1889 .

Off Fernandina, three immature specimens. Also at various Antillean stations in 125 to 805 fathoms, and off Cape Antonio, in 1,002 fathoms. Temperatures from $40^{\circ}$ to $50^{\circ} \mathrm{F}$. when recorded. U.S. Nat. Mus. Cat. No. 107979.

Nothing is more puzzling, when it comes to differentiating species from their shells alone, than these forms of Hyalina. How to weigh differences (apparently constant) of size, is a problem. In the absence of color or sculpture, the best conclusion must be tentative.

In view of the fact that Conrad's figures, though showing little finish, are usually characteristic, I am inclined to believe that the alleged type of the Academy of Sciences is not the original, as the figure represents a much stouter, shorter, and, so to speak, more normal Marginella. So I am disposed to resume my name for the slender, pure white, elongate abyssal species.

\section{Genus CYPRAEOLINA Cerulli-Irelli}

\section{CYPRA EOLINA HADRIA Dall}

Marginella (Volutella) hadria Dald, Bull. U.S. Nat. Mus. No. 37, p. 108, 1889.

Shell minute, involved, of an exact egg-oval form, white, polished; aperture narrow, slightly wider in front; outer lip thickened but with no groove behind it; pillar with a thin coating of enamel, pillar short with two prominent and two much less conspicuous plaits; body smooth. Length, 2.6; diameter, $2.8 \mathrm{~mm}$. U. S. Nat. Mus. Cat. No. 107984.

Off Georgia, eighteen, and off Fernandina, one specimen. Cedar Keys, Florida, Hemphill; Charlotte Harbor, Dall; Chesapeake Bay, Bahamas, and various Cuban localities; Henderson.

This is more globose and larger than C. lachrimula Gould.

\section{CYPRA EOLINA TINOLIA, new species}

Shell minute, ovate, involved, translucent white, smooth and polished, the anterior end a little attenuated; the aperture as long as the shell; outer lip thickened, slightly varicose, not crenulate; the lines of growth are extremely faint and there is no other sculpture; pillar very short with two large and two closely adjacent very minute plaits. Length, 3; diameter, $1.7 \mathrm{~mm}$. U. S. Nat. Mus. Cat. No. 107983. 
Off Fernandina.

Some of the specimens are more attenuated than others, but all are more elongated and narrow than C.hadria. There is also more of an excavation (not a groove) behind the thickened outer lip than in that species.

\section{CYPRAEOLINA TRUNCATA, new species}

Shell minute, translucent white, polished, the aperture rather wide, as long as the shell; spire involved, squarely truncate, the body of the shell more or less cylindrical, attenuated in front; outer lip straight, edentulous, moderately thickened; pillar with two strong and usually two very minute plaits behind the others, though at some stages of growth these last may be missing; the anterior edge of the pillar is twisted and merged into the outer lip with quite a marked depression behind it. Length, 2.3; diameter, $1.3 \mathrm{~mm}$. U. S. Nat. Mus. Cat. No. 108336.

Off Georgia and Fernandina, one specimen each.

This is a remarkably distinct species.

\section{Family VOLUTIDAE}

\section{Genus AURINIA Adams}

\section{AURinia GOULDIANA Dall}

Voluta gouldiana DALL, Conch. Exchange, vol. 2, p. 10, July, 1887.

Aurinia gouldiana DALL, Bull. Mus. Comp. Zoöl., vol. 18, p. 154, pl. 29, fig. 3, 1889; Trans. Wagner Inst., vol. 3, p. 81, pl. 7, fig. 2, 1890.

Off Georgia and Fernandina; also from off North Carolina to Key West, in 159 to 509 fathoms, bottom temperature, $45.2^{\circ}$ to $48.3^{\circ}$ F., living.

A fragment of this interesting species in which the reddish spiral bands are broken into squarish spots, was dredged in 50 fathoms off Key West, but was probably brought into shallow water by a fish.

\section{Family MITRIDAE \\ Genus MITRA Martyn \\ MITRA STYLIOLA, new species}

Shell small (immature), white, fusiform, with a translucent yellowish, smooth, polished nucleus of a whorl and a half and five or more subsequent whorls; suture distinct, hardly appressed; whorls flattish behind; axial sculpture of (on the last whorl about 20) vertical rounded ribs, crossing the whorls, with narrower or equal interspaces, but obsolete on the base; incremental lines obscure; spiral sculpture of numerous (on the last whorl about 23) equal and equally distributed even threads, with wider interspaces, hardly swollen at the 
intersections with the ribs and a little closer set on the canal; there is a small constriction dividing the first three threads in front of the suture from those succeeding them; aperture sublunate, outer lip thin (not mature), body erased, pillar with three plaits, canal straight, as long as the aperture; axis not pervious. Length of shell 11; of aperture and canal, 6; diameter, $5.5 \mathrm{~mm}$. U. S. Nat. Mus. Cat. No. 108440.

Off Georgia and Fernandina, not rare.

Near to M. styria Dall, but has more sharply cut ribs and the sculpture is not so regularly reticulate.

\section{MITRA ZILPHA, new species}

Shell small, dull white, fusiform, with a large smooth white nucleus of a whorl and a half and three and a half subsequent whorls; suture distinct, whorls moderately rounded, sometimes with a shoulder in front of the suture; axial sculpture of a variable number of rounded strong ribs (14 to 21 on the last whorl) with interspaces wider or narrower in conformity with the number of ribs, extending over the whorls but obsolete near the canal; spiral sculpture of fine threads, three or four on the penultimate and 10 or more on the last whorl, with wider interspaces, overrunning but not nodulating the ribs; aperture semilunate, narrow, outer lip thin, smooth within, the body smooth, the pillar straight, with two rather strong oblique plaits; canal produced, axis minutely pervious. Length of shell, 6 ; of aperture and canal, 3 ; diameter, 3 mm. U.S. Nat. Mus. Cat. No. 107971.

Off Georgia and Fernandina, 16 specimens.

\section{MITRA RENDERSONI, new species}

Shell small, of about seven whorls exclusive of about three small smooth brownish nuclear whorls, color whitish with a brownish base darker near the periphery, which appears as a narrow brown band just behind the suture on the spire; axial sculpture of (on the last whorl about 10) rather sharp, nearly vertical ribs with wider interspaces, obsolete near the canal; spiral sculpture of (on the penultimate whorl about eight) rather feeble flattish threads stronger and more widely spaced toward the canal from which they are separated by a distinct sulcus; the canal carries two or three much stronger spiral threads; the periostracum is pale and fibrous; the suture distinct but not deep; aperture narrow, the outer lip sharp, lirate internally, the pillar with three plaits, the canal moderately differentiated, slightly recurved. Length of shell, 17 ; of last whorl, $10 ; \max$. diameter, 6 mm. U. S. Nat. Mus. Cat. No. 333435.

Off Georgia, one specimen with hermit crab. 
This would seem to be a relatively shallow-water species, obtained in considerable numbers in the region of the Florida Keys and the Antilles by the late John B. Henderson, jr., in whose honor it is named.

\section{MITRA GRAMMATULA, new species}

Shell small, short fusiform, of about five whorls with a minute smooth nucleus of a whorl and a half; color pale brown, darker in the spiral interspaces which show in the throat as dark lines; suture minutely channeled; spiral sculpture of (on the penultimate whorl three, on the last whorl about a dozen) strong squarish cords with narrower interspaces, growing smaller toward the canal and covering the entire whorl; the cord in front of the suture is separated by a somewhat wider and deeper interspace from those in front of it; axial sculpture of numerous equal regular narrow sulci, cutting the stronger spirals into squarish nodules but less evident on the base; aperture narrow, pillar with two rather obscure plaits; canal hardly differentiated. Length, 4.5; diameter, 2.3 mm. U. S. Nat. Mus. Cat. No. 333456.

Off Georgia, two specimens.

This verges toward Mitromorpha.

\section{MITRA WANDOËNSIS Holmes}

Volutomitra wandoënsis Holmes, Postpliocene foss. S. Car., p. 57, pl. 10, figs. 10, 10 a., 1860.

Mitra rushii DALL, Conch. Exchange, vol. 2, p. 9, 1887.

Off Georgia, two specimens. From Cape Hatteras to the Gulf of Mexico, in 12 to 60 fathoms; United States Fish Commission.

\section{Genus MITROMORPHA A. Adams}

\section{MITROMORPHA BIPLICATA Dall}

Mitromorpha biplicata DALL, Bull. Mus. Comp. Zoöl., vol. 18, p. 165, pl. 35, fig. 1, 1889.

Off Fernandina, three specimens.

\section{MITROMORPHA UNDULATA, new species}

Shell small, white, of about five whorls, including one rather large smooth nuclear whorl; suture undulate, appressed; spiral sculpture of (on the penultimate whorl four, on the last whorl about a dozen) prominent equal cords, slightly swollen where they cross the ribs, the posterior cord somewhat more widely separated from the rest; axial sculpture of (on the penultimate whorl nine) rounded ribs with equal or wider interspaces, crossing the whorls but becoming obsolete toward the end of the last whorl; aperture narrow, outer lip sharp, lirate within; pillar with two well-marked pustulations, canal short, slender, slightly recurved. Length, 7.5; length of last whorl, 5; diameter, 4 mm. U. S. Nat. Mus. Cat. No. 107995.

Off Fernandina, one specimen. 
This is one of those forms which it is questionable whether to place it in Mitra or Mitromorpha.

\section{Family FASCIOLARIDAE}

\section{Genus FASCIOLARIA Lamarck}

FASCIOLARIA, species

A fragment was obtained off Georgia which included part of the last whorl and canal of what appears to be a small species of Fasciolaria. The suture is minutely channeled, there are seven obsolete knoblike axial ribs chiefly confined to the periphery, behind which the whorl is slightly constricted. The minor sculpture comprises numerous fine spiral threads in front of the suture minutely reticulated by prominent incremental lines giving a minutely punctate appearance. The canal is long, with three threadlike fine plaits on the pillar. The fragment measures about $12.5 \mathrm{~mm}$. in length. U. S. Nat. Mus. Cat. No. 347843.

The species is doubtless new, but can not be adequately described from the imperfect specimen.

\section{Genus FUSINUS Rafinesque}

? FUSINUS SCHRAMMI Crosse

Fusus schrammi Crosse, Journ. de Conchyl., vol. 13, p. 31, pl. 1, fig. 9, 1865.

Off Georgia and Fernandina, five very young specimens which may be immature individuals of the species described by Crosse from Guadelupe.

FUSINUS BULLATUS, new species

Shell small (possibly immature), pale gray, of about three whorls, exclusive of the large, swollen, smooth, white nucleus of nearly two whorls; spiral sculpture of a prominent undulated keel at the periphery with a smaller simple cord in front of it, the interval and the rest of the whorl behind the keel very finely closely threaded; on the base there are about eight stronger threads with wider interspaces, sometimes with an intercalary fine threadlet; there are no developed ribs, except as indicated by the dozen prominent nodes on the peripheral keel, yet in older specimens they may develop; the suture is closely appressed; the aperture is subovate, not lirate within and with the outer lip not thickened; the pillar is smooth, gyrate, and the axis pervious; the canal is slender, moderately long and slightly curved. Length, 10; length of last whorl, 5; diameter, $4 \mathrm{~mm}$. U.S. Nat. Mus. Cat., No. 107998.

Off Fernandina, one specimen.

\section{FUSINUS VITREUS, new species}

Shell small, white, thin, with an inflated smooth, white nucleus of two whorls and three and a half subsequent whorls; suture distinct, 
more or less undulated by the sculpture; axial sculpture of (on the last whorl 10 or 11) well-marked rounded ribs with equal or wider interspaces, crossing the whorls on the spire, obsolete on the base, and very fine silky incremental lines; spiral sculpture of (on the spire two) cords near the periphery and one close to or hidden by the succeeding suture; these become prominent on the periphery of the last. whorl and nodulose where they cross the ribs; in front of them the base and canal are sculptured with very fine close spiral threads; aperture moderate, outer lip simple, body with a thin wash of enamel; canal well developed, flexuous; axis minutely pervious. Length of shell, 9.5; of aperture and canal, 4.5 ; diameter, $5 \mathrm{~mm}$. U. S. Nat. Mus. Cat. No. 108317.

Off Georgia, numerous specimens.

\section{Family CHRYSODOMIDAE \\ Genus CHRYSODOMUS Swainson \\ Subgenus Siphonorbis Mörch \\ SIPHONORBIS PERMINUTUS, new species}

Shell small (immature?), stout, white, with a planorboid white nucleus of one and a half whorls, and three and a half subsequent wellrounded, rapidly increasing whorls; suture distinct, not deep; axial sculpture of rather obvious fine close incremental lines which minutely crenulate the spiral; spiral sculpture of (on the penultimate whorl half a dozen) fine spiral threads with wider interspaces which on the last whorl grow closer and coarser anteriorly, covering the whole whorl; aperture ovate, outer lip thin, body erased, pillar attenuated in front, canal slender, narrower anteriorly. Length of shell, 9 ; of aperture and canal, 6.5 ; diameter, $5 \mathrm{~mm}$. U. S. Nat. Mus. Cat. No. 107996.

Off Georgia and Fernandina, not rare.

The nucleus begins smoothly, quickly develops faint spirals, these gradually increase in strength and merge into the spirals of the adult sculpture; the nucleus of $S$. ebur Mörch, type of the subgenus, is very similar. Most of the specimens obtained were immature and it is not certain that that largest specimen, on which the diagnosis is based, is fully adult.

\section{Family COLUMBELLIDAE}

\section{Genus ASTYRIS H. and A. Adams}

\section{ASTYRIS PURA Verrill}

Astyris pura Verrill, Trans, Conn. Acad., vol. 5, pt. 2, p. 515, June, 1882.Bush, Bull. Mus. Comp. Zoöl., vol. 23, p. 240, pl. 1, fig. 13, 1893.

Off Fernandina, 14 specimens. Off the eastern coast of the United States from Cape Cod to Florida, in 70 to 484 fathoms; United States Fish Commission. 
ASTYRIS PERLUCIDA, new species

Shell minute, slender, white or yellowish, thin, with an inflated smooth nucleus of a whorl and a half and about three subsequent whorls; suture distinct, not appressed; whorls moderately rounded, smooth except for very fine regular incremental lines only visible with a lens; there are very faint spiral striae on the base and back of the canal; aperture sublunate, outer lip thin, simple, body enameled, pillar straight, canal distinct, slightly recurved; axis minutely or not at all pervious. Length of shell, 5 ; of aperture, 2 ; diameter, $2 \mathrm{~mm}$. U.S. Nat. Mus. Cat. No. 108001.

Off Fernandina, about 20 specimens.

Similar to $A$. pura but with rounder, thinner, and more translucent whorls, and somewhat more elevated spire.

ASTYRIS STEMMA, new species

Shell small, slender, white, with a small blunt white nucleus of about one whorl and five subsequent rather flattish whorls; suture distinct, not deep; axial sculpture of obscure incremental lines; there is no spiral sculpture; in front of the suture the edge of the succeeding whorl is very slightly and narrowly turrited; the base is gradually attenuated; aperture short, semilunate; the outer lip thin, smooth, nearly vertical; the body without glaze, the pillar short and twisted; the axis minutely pervious. Length of shell, 6; of aperture, 2; diameter, $2 \mathrm{~mm}$. U. S. Nat. Mus. Cat. No. 108003.

Off Fernandina, abundant.

This is more elongated than either of the others.

\section{Section FLUELLA Dall}

Like Astyris but spirally sculptured without conspicuous axial sculpture.

\section{ASTYRIS (FLUELLA) VIDUA Dall}

Astyris (Fluella) vidua DAll, Proc. Biol. Soc. Wash., vol. 37, p. 87, 1924.

Shell small, thin, translucent white, with an inflated, smooth nucleus of a whorl and a half, and about three subsequent well-rounded whorls; suture distinct, not appressed; axial sculpture only of faint incremental lines; spiral sculpture of numerous equal and equally spaced spiral striae covering the whole shell but stronger on the last whorl; aperture semilunate, outer lip thin, simple, a slight swelling behind it; body with a thin layer of enamel; pillar short, slightly recurved; canal hardly differentiated from the aperture, axis pervious. Length of shell, 4 ; of aperture, 1.7 ; diameter, $2.5 \mathrm{~mm}$. U. S. Nat. Mus. Cat. No. 108002.

Off Fernandina, abundant.

This may be taken as the type of the new section. 
Tryon placed shells like these with Seminella, but the solid bright colored tropical shells which are typical of that genus can hardly be closely associated with the present group.

\section{ASTYRIS (FLUELLA) AMPHISSELLA Dall}

Columbella (Astyris?) amphissella Dald, Bull. Mus. Comp. Zoöl., vol. 9, p. 91,1881 ; vol. 18 , p. 188 , pl. 19, fig. 10 e, 1889 .

Shell minute, thin, white, with an inflated smooth nucleus of one and three subsequent whorls; suture distinct, not deep, whorls well rounded; spiral sculpture variable, obsolete on some specimens and quite evident on others, composed of very fine equal spiral striae; axial sculpture also variable in strength, when best developed (as in the specimen selected as type), there are on the last whorl about 24 fine sharp slightly flexous riblets, obsolete beyond the periphery, with narrower interspaces; aperture subovate, outer lip slightly thickened, simple; body with a coat of enamel; pillar short, canal short but sharply recurved. Length of shell, 4.5 ; of aperture, 2.5; diameter, $2 \mathrm{~mm}$. U. S. Nat. Mus. Cat. No. 108323.

Off Georgia, abundant.

\section{ASTYRIS (FLUELLA), variety RUSHII Dall.}

Anachis amphissella, variety rushii DaLL, Bull. Mus. Comp., Zoöl vol. 18, p. $188,1889$.

Off Georgia, numerous, with the type. Off Fowey Rocks, in 465 fathoms; Dr. W.H. Rush.

\section{ASTYRIS (FLUELLA) ENIDA, new species}

Shell small, thin, white, with an inflated translucent nucleus of a whorl and a half and about four subsequent moderately shouldered, well-rounded whorls; suture distinct, not appressed; axial sculpture of few, irregularly distributed, thin sharp low lamellae, crossing the whorls and more or less obvious incremental lines; spiral sculpture covering the shell, of fine equal, and mostly equally spaced, threads with usually narrower interspaces; aperture ovate, body and pillar with a thin coat of enamel; outer lip thin, simple, not varicose; canal short, recurved; axis pervious. Length of shell, 6 ; of aperture, 2.7; diameter, $2.5 \mathrm{~mm}$. U. S. Nat. Mus. Cat. No. 108324.

Off Georgia and Fernandina, common.

The periostracum is pale, fibrous, and usually dehiscent.

\section{ASTYRIS (FL UELLA) APPRESSA, new species}

Shell, small, short, stout, white, with an inflated blunt nucleus of a whorl and a half and about three subsequent whorls; suture distinct, not appressed; spiral sculpture of fine close equal even and evenly distributed threads covering the whole shell; axial sculpture of a few irregularly distributed obscure ridges most obvious on the 
spire, and very fine close well-marked incremental lines; aperture narrow, outer lip varicose with five or six denticles within, body with a thick coat of enamel, pillar short, canal very short, but recurved. Length of shell, 6; of aperture, 3; diameter, $3 \mathrm{~mm}$. U. S. Nat. Mus. Cat. No. 108326.

Off Georgia and Fernandina, nine specimens.

The prominent characteristic of the typical shell is the way the rotundity of the whorls is suppressed so as to indicate a smooth spindle shape for the whole shell.

A variety? (333458) from the same station is more slender, and has the upper whorls nearly smooth and the threads on the last whorl coarser and the varix less prominent.

\section{Section PLECTARIA Dall 1924}

Like Astyris but with predominant axial sculpture.

ASTYRIS (PLECTARIA) CRUMENA Dall

Astyris (Plectaria) crumena DaLL, Proc. Biol. Soc. Wash., vol. 37. p. 87, 1924.

Shell short, small, stout, white, with an inflated translucent nucleus of a whorl and a half and about three subsequent whorls; suture distinct, not deep, whorls well rounded, rapidly increasing; axial sculpture of (on the last whorl about 14) rounded ribs, crossing the whorl, with wider interspaces; spiral sculpture of numerous fine equal threads equally distributed over the whole whorl and not nodulous where they cross over the ribs; aperture ovate, outer lip simple, varicose; body with a wash of enamel, pillar short, canal wide and short, not recurved; axis minutely pervious. Length of shell, 4; diameter, $3 \mathrm{~mm}$. U. S. Nat. Mus. Cat. No. 108006.

Off Fernandina, three specimens.

These shells on account of their axial sculpture were formerly referred to Anachis the type of which is Columbella scalarina Sowerby, which obviously can not be associated with shells of the present group, of which the above species may be taken as type. They are clearly related closely to Astyris, of which the type is $C$. rosacea Gould.

\section{ASTYRIS (PLECTARIA) EMBUSA, new species}

Shell small, stout, white, with a large smooth polished nucleus of a whorl and a half, and about four subsequent whorls; suture deep, not appressed, whorls very rotund; axial sculpture of (on the last whorl about a dozen) strong narrow rounded ribs with wider interspaces, crossing the whorls; spiral sculpture of numerous equal and equally distributed fine threads with narrower interspaces, not swollen where they pass over the ribs, and visible over the whole shell; last whorl much the largest; aperture rather short and wide, a glaze 
on the body, the outer lip simple, not internally lirate and mostly sharp-edged; pillar with a coat of enamel in adults, short, smooth; canal short, slightly recurved. Length of shell, 4.5; of last whorl, 2.5; diameter, $2.4 \mathrm{~mm}$. U. S. Nat. Mus. Cat. No. 108322.

Off Georgia, very abundant.

ASTYRIS (PLECTARIA) EURIBIA, new species

Shell minute, subfusiform, white, extremely variable, with a smooth blunt nucleus of a whorl and a half and somewhat less than three subsequent whorls; suture distinct, not appressed; whorls rounded; axial sculpture of slightly flexuous narrow riblets, usually with wider interspaces, varying from none at all to 24 on the last whorl, crossed by numerous fine spiral threads, equal and closely spaced over the whole shell, strong in some specimens, obsolete and barely perceptible in others, not anywhere nodulous; aperture subovate, outer lip nearly straight, hardly thickened, smooth within; body with a thin layer of enamel; pillar short, canal very short, axis pervious. Length of shell, 4; of aperture, 2; diameter, $2 \mathrm{~mm}$. U. S. Nat. Mus. Cat. No. 108205 .

Off Fernandina, abundant.

The ribs are threadlike, sometimes almost like elevated lines and sometimes hardly more prominent than incremental lines, while the spiral sculpture is very feeble and sometimes hardly perceptible.

\section{AStYris (Plectaria) Projecta, new species}

Shell small, slender, white, with a blunt smooth inflated nucleus of a whorl and a half and about four and a half subsequent slightly shouldered whorls; suture distinct, not deep, narrowly appressed; early whorls with about 14 feeble, irregular, narrow riblets crossing the whorls, with wider interspaces, growing feebler with the growth of the shell and obsolete or absent (in the type specimen) on the last whorl; incremental lines feeble; spiral sculpture only of a few obsolete lines on the back of the canal; aperture subovate, body erased, outer lip thin, simple, pillar short, twisted, canal hardly differentiated from the aperture; axis impervious. Length of shell, 6; of aperture, 1.6; diameter, 2 mm. U. S. Nat. Mus. Cat. No. 108004.

Off Fernandina, one specimen.

\section{ASTy Ris (Plectaria) Albella C. B. Adams}

Pleurotoma albella C. B. Adams, Contr. Conch., vol. 1, p. 63, 1850. Anachis acuta Stearns, Tryon Man., vol. 5, p. 158, pl. 55, fig. 66, 1883.

Shell small, elongated, slender, white, with a smooth blunt inflated nucleus of a whorl and a half and about four and a half rather flatsided subsequent whorls; suture distinct, not deep; axial sculpture of (on the penultimate whorl about 14) vertical rounded ribs, crossing the whorls on the spire, with subequal interspaces; on the last 
whorl fainter and obsolete beyond the periphery, the incremental lines faint; spiral sculpture confined to the canal, of fine close threads; aperture narrow, outer lip thin, with a slight thickening behind it, smooth inside; pillar nearly straight; canal well defined; axis minutely pervious. Length of shell, 8 ; of aperture 2.5 ; diameter, 2.5 mm. U. S. Nat. Mus. Cat. No. 108007.

Off Fernandina, numerous.

This is quite close to C. verrilli Dall, and may prove identical; one specimen shows brownish obscure color marks, but these may be accidental.

ASTYRIS (PLECTARIA), sp. indet

A species of Astyris, too dilapidated to identify specifically, was collected off Georgia (No. 108325) and there are similar specimens in the collection dredged off Fowey Rocks, Florida Strait, in 209 fathoms, by the late John B. Henderson, jr.

\section{Section PARASAGENA Dall, 1924}

Shells resembling Astyris, but with a sharply cut, open reticular sculpture.

Type.-Astyris (Parasagena) georgiana Dall.

ASTYRIS (PARASAGENA) GEORGIANA Dall

Astyris (Parasagena) georgiana Dall, Proc. Biol., Soc. Wash., vol. 37, p. 87, 1924 .

Shell small, translucent white, biconic, with a smooth white inflated nucleus of a whorl and a half, and about four subsequent moderately convex whorls; suture distinct, not appressed, with an elevated thread on its anterior margin; axial sculpture of (on the last whorl 12 to 14 ) narrow vertical rounded ribs with wider interspaces, crossing the whorls, and rather conspicuous incremental lines; spiral sculpture of (on the spire two, on the last whorl about nine) very distinct equal fine threads, over running the ribs without nodulation, with wider interspaces, more close on the base, and fine intercalary striae, chiefly visible in the interspaces and there minutely reticulating the incremental lines; aperture rather narrow, the outer lip hardly thickened except when coincident with a rib, smooth inside; the body and pillar short, the canal hardly differentiated from the aperture. Length of shell, 5; of aperture, 2.5; diameter, $2.5 \mathrm{~mm}$. U. S. Nat. Mus. Cat. No. 108311.

Off Georgia, many specimens.

This species has a vitreous appearance and the wide shallow reticulation is notable.

ASTYRIS (PARASAGENA) SAGENATA, new species

Shell small, whitish, with a smooth nucleus of one and a half whorls and about three or four and a half subsequent whorls; suture 
distinct, undulate, with a space on each side between it and the nearest spiral cord; spiral sculpture of (on the penultimate whorl 5, on the last whorl about 14) equal and equally distributed small cords with much wider interspaces, little swollen where they cross the ribs, and covering the whole shell; axial sculpture of (on the last whorl about 11) rounded narrow ribs with much wider interspaces, crossing the whole whorl, and in the interspaces conspicuous fine incremental lines; aperture rather wide, outer lip sharp with 4 or 5 small pustular denticulations well within the margin; pillar smooth, slightly concave, canal short, a little recurved. Length of shell, 6; of last whorl, 4; diameter, 3 mm. U. S. Nat. Mus. Cat. No. 108312.

Off Georgia, 16 specimens.

The specimens obtained have been discolored by their stay on the bottom and are of a brownish color like many of the other specimens obtained from these two localities.

\section{Section ATILIA H. and A. Adams}

COLUMBELla (ATILIA?) MYSTICA, new species

Shell small, slender, solid, pale brown (faded ?) with a smooth nuclear whorl and a half, and four and a half subsequent whorls; suture distinct, whorls well rounded; spiral sculpture of (on the spire two, on the last whorl four) prominent cords near the periphery with wider interspaces, and smaller close set threads on the base and in front of the suture; axial sculpture of (on the last whorl about a dozen) rather feeble rounded ribs with narrower interspaces, these extend more or less obviously over the whorl; aperture ovate; outer lip thin, denticulate within, inner lip smooth, canal short, strongly spirally threaded, slightly recurved. Length, 4.3 ; diameter, $1.5 \mathrm{~mm}$. U.S. Nat. Mus. Cat. No. 108321.

Off Georgia, one specimen.

Aesopus filosus Angas (= Columbella plurisulcata Reeve) from Port Jackson, Australia, is somewhat such a shell as this, and is referred by Tryon to Atilia. But if $C$. suffusa as indicated by Pace is the type of Atilia, the present species can hardly be referred to the same group. Without more material and investigation of what the Australian shell involves, I hesitate to give a new sectional name.

\section{Family MURICIDAE}

\section{Genus PTEROPURPURA Jousseaume}

\section{PTEROPURPURA TRISTICHA Dall}

Pteronotus tristichus DALl, Bull. Mus. Comp. Zoöl., vol. 18, p. 202, pl. 15, fig. 3, 1889.

Off Georgia and Fernandina, one well grown and many young shells. Off Cuba in 152 to 450 fathoms, U. S. S. Blake. 


\section{Genus UROSALPINX Stimpson}

There is a group of small deep water shells referred by Verrill to this genus, to which they bear a certain resemblance, but of which the dentition and other anatomical characters are as yet unknown. To this belong $U$. carolinensis and $U$. macra Verrill, and apparently the following species. I confess to doubt as to their proper place and whether they really belong to the genus typified by U. cinereus Say, but in advance of further information it seems best to leave them, tentatively, where Verrill placed them.

\section{? UROSALPINX VERRILLI, new species}

Shell small, white, fusiform, with a smooth white nucleus of about one smooth small whorl followed by a second minutely reticulate whorl, on which the spiral threads are stronger, increasing in strength to the end of the nuclear portion, and three subsequent well rounded whorls; suture distinct and deep, not appressed; axial sculpture of (on the last whorl about 15) narrow rounded ribs crossing the whorls, with wider interspaces; the incremental lines are fine even, closely adjacent, and of a silky texture; the ribs are obsolete on the base of the last whorl; spiral sculpture of (on the penultimate whorl 6; on the last whorl 11) equal and equally spaced rounded cords with subequal interspaces (in which occasionally some fine spiral striae occur) and 10 or more close-set simple cords on the base; the former are slightly swollen at their intersections with the ribs; aperture semilunate, the outer lip thin, smooth internally, the body erased, the pillar short, twisted, the canal short and recurved; the axis impervious. Length of shell, 9 ; of aperture, 4.5 ; diameter, $4.5 \mathrm{~mm}$. U. S. Nat. Mus. Cat. No. 108319.

Off Georgia, abundant.

\section{? UROSALPINX STIMPSONI, new species}

Shell small, fusiform, white, with an inflated, smooth white nucleus of a whorl and a half and nearly four subsequent whorls; suture distinct, rather deep, whorls well rounded; early whorls more or less distinctly ribbed with about 16 rounded ribs on the penultimate whorl, obsolete on the last whorl, with more or less obvious close incremental lines; spiral sculpture of (on the penultimate whorl 6; on the last whorl about 20) equal and equally distributed cords with usually wider interspaces in each of which runs a fine intercalary thread; this sculpture covers the whole whorl; aperture sublunate, outer lip thin, sharp, crenulate by the sculpture; body lightly erased, pillar smooth, twisted; canal short, slightly recurved; axis pervious. Length of shell, 10; of aperture and canal, 4.5; diameter, $6 \mathrm{~mm}$. U. S. Nat. Mus. Cat. No. 107999.

Off Georgia and Fernandina, 11 specimens. 


\section{Genus CORAlliophila H. and A. Adams}

CORALLIOPHILA LACTUCA Dall

Coralliophila lactuca Dall, Bull. Mus. Comp. Zoöl., vol. 18, p. 220, pl. 16, fig. 6, 1889.

Off Fernandina, Fla., at station 2669, in 352 fathoms, sand, bottom temperature, $43.7^{\circ} \mathrm{F}$. Also off Cuba in the Gulf of Mexico in 152 to 229 fathoms, ooze, bottom temperature, $49.5^{\circ} \mathrm{F}$.

This was found so near station 2668 that it seemed proper to include it.

\section{Subfamily THAISINAE \\ Genus THAIS Bolten}

THAIS FLORIDANA Conrad

Purpura floridana Conkad, Journ. Acad. Nat. Sci. Phila., ser. 1, vol. 7, p 265, pl. 20, fig. 21, 1837.

Off Fernandina, one very young dead specimen.

This specimen was evidently due to drift from the shore or disgorgement by some fish or bird.

\section{Family EPITONIIDAE}

\section{Genus EPITONIUM Bolten}

\section{EPITONIUM MARCOËNSE, new species}

Shell small, white, acute with a translucent nucleus of three and six subsequent rounded adjacent whorls; axial sculpture of (on the last whorl about 22) low thin sharp simple varices with wider interspaces and not continuous over the suture; spiral sculpture of almost microscopic fine striae, uniform over the whorls; base with no disk, aperture nearly circular. Length, 8 ; diameter, $3 \mathrm{~mm}$. U. S. Nat Mus. Cat. No. 108017.

Off Fernandina, 10 specimens, mostly young; off Georgia six specimens. Beach at Marco, Fla., common; Olson.

The spiral striation is only visible under a lens in a good light.

EPITONIUM FRACTUM, new species

Shell small, decollate, with four well-rounded whorls remaining, with a dull surface, white, and rather laxly coiled; suture distinct, deep; axial sculpture of (on the last whorl 13) thin low slightly oblique sharp lamellae, continuous in the depth of the suture and up the spire, making about one-third of a turn around the shell; there is no spiral sculpture (though the edges of the lamellae look more or less irregular, it may be due to wear); the base is evenly rounded without a disk, and imperforate; aperture rounded with a thin slightly expanded margin. Length of four whorls, 9.5 ; of aperture, 3 ; diameter, $4 \mathrm{~mm}$. U. S. Nat. Mus. Cat. No. 108015.

Off Fernandina, one specimen. 


\section{EPITONIUM AZELOTES, new species}

Shell small, solid, white, with a minute brown reticulate nucleus of two and a half whorls and about six subsequent well-rounded whorls; suture distinct; axial sculpture of (on the last whorl about 16) strong squarish ribs with equal or narrower interspaces and more or less obvious incremental lines; spiral sculpture of (on the early whorls 2, later 3 , and on the last whorl 4) strong cords, which make with the ribs deep reticulations but are not nodulous at the intersections with the ribs; the anterior cord is within the rounded margin of the base, and between it and the axis the surface is nearly smooth and slightly concave; aperture rounded, the outer lip crenulate by the sculpture; the axis is impervious. Length of shell, 4 ; of aperture, 0.75 ; diameter, 1.7 mm. U. S. Nat. Mus. Cat. No. 108370.

Off Georgia, one specimen.

This is a very characteristic form, having somewhat the aspect of a Mathilda. I have found nothing figured which approaches it.

\section{EPITONIUM, species}

A small, probably immature, shell, white, with a small acute white nucleus of two and a half whorls, and four rapidly enlarging subsequent adjacent whorls with about a dozen solid smooth varices continuous over the suture; spiral sculpture of fine striae perceptible on the earlier whorls, more or less obsolete on the later ones; there is no basal disk and the axis is imperforate. Length, 3.2; diameter, $1.5 \mathrm{~mm}$. U. S. Nat. Mus. Cat. No. 108872.

Off Georgia, one specimen.

In doubt as to whether this may not be the young of a larger species, I refrain from naming it.

\section{EPITONIUM OPALINUM, new species}

Shell small, translucent white, elongated, with a dark-brown, minutely reticulate nucleus of three small whorls and about a dozen subsequent whorls; suture distinct, not impressed, with a single simple thread immediately behind it; axial sculpture of (on the last whorl 17 to 25) narrow rounded vertical ribs crossing the whorls, with wider interspaces, and very minute regular close-set sharp incremental lines; the base shows the feeble ends of the ribs radiating from the axis; spiral sculpture of (on the last whorl 9 or 10) fine equal simple threads, with usually subequal narrower interspaces, not swollen where crossing the ribs at the intersections; at the periphery of the whorl is an angle or small ridge which appears behind the suture on the spire; the base is flattish or even slightly concave without spiral sculpture; aperture subquadrate with thin margin, the axis imperforate. Length of shell, 10.5; of aperture, 1.5; diameter, 2.5 mm. U. S. Nat. Mus. Cat. No. 108368.

Off Georgia, 13 specimens.

The flattish whorls and shallow suture recall Opalia. 
EPITONIUM LAVARATUM, new species

Shell white with a reticulated brown elongated nucleus of about three whorls and 9 or 10 subsequent whorls; suture deeply constricted, not solute; whorls well and evenly rounded with a large smooth basal disk; axial sculpture of (about 16 on the last whorl) equal rounded ribs with wider interpaces, interspersed on the later whorls with heavier varices; fine incremental lineation also occurs; spiral sculpture of 10 or more threads with wider interspaces and more or less spiral striation; the base is imperforate, the aperture rounded. Length, 10; diameter, $3 \mathrm{~mm}$. U. S. Nat. Mus. Cat. No. 347845 .

Off Georgia in large numbers, but mostly worn and discolored.

\section{EPITONIUM DISCOBOLARIUM Dall}

Scala (Opalia) discobolaria DaLl, Bull. Mus. Comp. Zoöl., vol. 18, p. 324, pl 18, fig. 2, 1889.

Shell small, whitish, acute with eight rather rapidly enlarging whorls exclusive of the (lost) nucleus; suture well marked, somewhat undulate; whorls well rounded, with a brown basal disk the edge of which is usually covered by the suture; axial sculpture of (on the last whorl 14) strong rounded low ribs with wider interspaces, and obvious incremental lines in the interspaces; spiral sculpture of (on the last whorl five or six) sharp narrow grooves, with wider interspaces, which also cut the ribs; on the basal disk there is a relatively smooth border cut by a feeble median stria, inside this border there are five or six spiral grooves pretty close together; the shell is imperforate and the aperture roughly quadrate; the ribs are not continuous up the spire. Length, 7.5 ; diameter, $3.5 \mathrm{~mm}$. U. S. Nat. Mus. Cat. No. 333461.

Off Fernandina and Georgia, two specimens.

This has a general resemblance to E. lavaratum but the sculpture is different and the basal disk not smooth as in that species. The original type of this species was in bad order and the diagnosis of a more perfect specimen is now furnished.

\section{EPITONIUM CANIUM, new species}

Shell small, slender, whitish, with a brown reticulate acute nucleus of three, and eight subsequent whorls; suture deeply constricted but not solute; whorls inflated; spiral sculpture of (on the last whorl five or six) rounded cords, equally distributed with somewhat wider interspaces, overrunning the ribs and slightly swollen at the intersections; there is a well-marked basal disk the edge of which is covered by the suture, and which carries five or six fine close spiral threads; axial sculpture of (on the last whorl 15) strong rounded ribs, the final rib 
or varix larger than the others; base imperforate, aperture rounded. Length, 6.5; diameter, 2 mm. U. S. Nat. Mus. Cat. No. 333464.

Off Georgia, four specimens.

Genus OPALIA H. and A. Adams

OPALIA, sp. indet.

A fragment of an undescribed Opatia was obtained off Fernandina, which showed about 14 strong low rounded varices and fine silky incremental sculpture crossed by 9 or 10 extremely delicate fine spiral threads with much wider interspaces. The height of the whorl is 5 and the diameter $9 \mathrm{~mm}$. U. S. Nat. Mus. Cat. No. 108014.

OPALIA? DROMIO, new species

Shell small, solid, white, with a brown reticulate three-whorled acute nucleus and eight well rounded subsequent whorls; suture deep, not appressed, not crossed by the axial ribs; axial sculpture of (on the last whorl 17) rather stout rounded ribs with subequal interspaces, not continuous up the spire; spiral sculpture of microscopic faint spiral striae hardly modifying the ribs; basal disk smooth, bordered by a raised line; aperture rounded, axis imperforate. Length of shell, 6 ; of aperture, 1 ; diameter, $2 \mathrm{~mm}$. U. S. Nat. Mus. Cat. No. 108018.

Off Fernandina, six specimens

\section{Family MELANELLIDAE}

\section{Genus MELANELLA Bowdich}

MELANELLA CALLISTEMMA, new species

Shell small, slender, white, flat-sided, with a blunt apex and about ten whorls; suture distinct, appressed; sculpture of faint incremental lines and an occasional varical stria; base rounded, imperforate; aperture subovate, outer lip thin, simple, somewhat patulous, inner lip short. Length of shell, 5.7; of aperture, 1.3; diameter, $1.6 \mathrm{~mm}$. U. S. Nat. Mus. Cat. No. 108035.

Off Fernandina, three specimens.

This is not unlike $M$. rectiuscula Dall, but the latter is larger and has more rounded whorls.

\section{MELANELLA OLEACEA Kurtz and Stimpson}

Eulima oleacea Kurtz and Strmpson, Proc. Boston Soc. Nat. Hist., vol. 4, p. 115, Dec. 1851.-Tryon, Man., vol. 8, p. 273, pl. 69, fig. 36, 1886.

Shell small, straight, conical, translucent white, rarely with pale brownish spiral bands, smooth, polished, with a blunt apex and about a dozen flattish whorls rather rapidly increasing in diameter; suture obscure, over-glazed; base evenly rounded without an umbilical dimple; aperture sublunate, outer lip simple, slightly flexuous, body with 
a layer of enamel, inner lip short and heavy. Length of shell, 9.2; of aperture, 2.5; diameter, $3.3 \mathrm{~mm}$. U. S. Nat. Mus. Cat. No. 108375 .

Off Georgia, 10 specimens.

The specimen described by Stimpson and figured by Tryon is young; the brownish bands are not constant in fresh specimens and fade in the cabinet. A description is therefore given of the adult shell, which agrees with specimens identified as $M$. oleacea from Vineyard Sound, by Professor Verrill.

\section{MELANELLA CONOIDEA Kurtz and Stimpson}

Eulima conoidea Kurtz, and Stimpson, Proc. Boston Soc. Nat. Hist., vol. 4 , p. 115.-Tryon, Man., vol. 8, p. 273, pl. 69, fig. 40, 1886.

Shell small, solid, polished, white, with a blunt apex, slightly bent spire, and about eleven whorls; suture obscure, with an over-glaze; the whorls enlarge rather rapidly; there is no perceptible sculpture; base evenly rounded; aperture short, sublunate, the outer lip simple, flexuous, the body with a layer of enamel, the inner lip thickened. Length of shell, 9.5 ; of aperture, 2 ; diameter, $3 \mathrm{~mm}$. U.S. Nat. Mus. Cat. No. 108026.

Off Fernandina, one specimen; South Carolina, Kurtz.

This is very much like $M$. oleacea but the last whorl is not so much expanded, the sides are flatter, and in the adult the carination of the last whorl mentioned by Stimpson, a feature of immaturity, does not appear.

MELANELLA PENNA, new species

Shell small, conical, smooth, polished, creamy white with a blunt apex and eight flattened whorls; suture obscure, appressed, lightly over glazed; surface without sculpture; aperture semilunate, outer lip simple, somewhat flexuous, body with a layer of enamel, inner lip slightly concave, with a perceptible umbilical depression behind it, the base evenly rounded. Length of shell, 5.7; of aperture, 1.5; diameter, $2 \mathrm{~mm}$. U. S. Nat. Mus. Cat. No. 108032.

Off Fernandina, five specimens.

This species appears to be nearly related to M. gracilis C. B. Adams, 1850 ; not of Jeffreys, 1848.

\section{MELANELla RECTIUSCula Dall}

Eulima (Liostraca) rectiuscula DALL, Trans. Wagner Inst., vol. 3, p. 160, 1890 .

Shell small, slender, polished, white, with a swollen blunt nucleus of two whorls and ten subsequent slightly convex whorls; suture distinct, shallow, not glazed over; sculpture only of faint incremental lines; base elongately rounded, imperforate; aperture subovate, outer lip simple, slightly convexly arcuate, inner lip short, slightly 
raised. Length of shell, 7 ; of aperture, 2 ; diameter, $1.7 \mathrm{~mm}$. U. S. Nat. Mus. Cat. No. 108033. The type is No. 87343.

Off Fernandina, four specimens.

This was entered in Bulletin 37, U. S. National Museum, under the name of $E$. stenostoma, but later comparisons with Jeffreys' European types showed that the two are distinct.

\section{MELANELLA FERNANDINAE, new species}

Shell minute, conic, polished, white, with a small blunt apex and about seven whorls; suture shallow, not glazed over; whorls flattish, base elongately rounded; there is no visible sculpture; aperture subovate, the outer lip thin, simple, slightly produced medially; inner lip short with a slight dimple behind it. Length of shell, 4.3; of aperture, 1.2 ; diameter, $1.5 \mathrm{~mm}$. U. S. Nat. Mus. Cat. No. 108034.

Off Fernandina, numerous specimens.

MELA NELLA CINCA, new species

Shell minute, polished, white, acute-conical, of about eight very slightly convex whorls; suture obscure, glazed over; sculpture of very faint incremental lines; base evenly rounded, imperforate; aperture subovate, short, margins thin, simple, outer lip prominently convexly arcuate. Length of shell, 3.2; of aperture, 0.8; diameter, $1 \mathrm{~mm}$. U. S. Nat. Mus. Cat. No. 108028.

Off Fernandina, five specimens.

\section{MELANELLA ABIDA, new species}

Shell small, solid, acute, white, the spire bent slightly to the right, with a minute blunt apex and about 10 whorls; suture obscure, not impressed; whorls flat, glazed over; base somewhat abruptly rounded, imperforate; sculpture absent, aperture ovate, outer lip thin, simple, produced arcuately, inner lip short, anterior margin slightly narrowed in front. Length of shell, 7; of aperture, 1.7; diameter, $2 \mathrm{~mm}$. U. S. Nat. Mus. Cat. No. 108030.

Off Fernandina, seven specimens.

\section{MELANELLA CORRIDA, new species}

Shell small, solid, white, with a faint indication of an ill-defined brownish band around the periphery of the later whorls; the spire bent slightly to the right, the 10 whorls flat-sided, the apex minute and blunt; suture obscure, glazed over; sculpture none visible, the last whorl about one-third of the whole length; base elongately rounded, aperture subovate, the margin thin, outer lip simple, medially arcuately produced. Length of shell, 6.5 ; of aperture, 1.5; diameter, 2 mm. U. S. Nat. Mus. Cat. No. 108376.

Off Georgia, 15 specimens.

$$
24105-27 \dagger-5
$$


Mela nella arCuAta, C. B. Adams

Eulima arcuata C. B. ADAMs, Contr. to Conch., p. 110, 1850 (not of Sowerby, 1866).

Shell minute, white, solid, the apex minute, blunt, the spire irregularly bent, chiefly to the right, with seven or eight flattish whorls; suture obscure, over-glazed; surface polished, without visible sculpture; base elongately rounded, imperforate; aperture narrow, slightly narrowed in front, margins thin, simple, the outer lip very slightly convexly arcuate. Length of shell, 4 ; of aperture, 1.5; diameter, $1.7 \mathrm{~mm}$. U. S. Nat. Mus. Cat. No. 108029.

Off Fernandina, numerous specimens. Jamaica, West Indies; Adams.

\section{MELANELLA OPHIODON, new species}

Shell minute, slender, thin, translucent white, the apex minute, blunt, the spire more or less arcuate, in the type bent to the right, with about 8 whorls; suture visible, appressed, over-glazed; surface polished without visible sculpture; aperture very short, somewhat patulous; base rounded, imperforate, the margin of the aperture thin, simple; the outer lip slightly protractively arcuate. Length of shell, 3.5 ; of aperture, 0.7 ; diameter, $1 \mathrm{~mm}$. U. S. Nat. Mus. Cat. No 108027.

Off Fernandina, one specimen.

Not unlike $M$. arcuata but proportionately more slender. In the former it is the early part of the spire which is bent; in the present species the whole shell is evenly arcuate.

\section{MELANELLA ANACHOREA, new species}

Shell minute, smooth, transparent whitish, thin, the apex slightly brownish, minute and blunt, with about 10 whorls, the spire slightly bent backward; suture appressed, glazed over, the whorls flattish; base rounded, imperforate; aperture narrowly sublunate, the outer lip thin, moderately convexly arcuate, inner lip very short, thin, body without enamel. Length of shell, 5 ; of aperture, 1.2 ; diameter 1.5 mm. U. S. Nat. Mus. Cat. No. 108377.

Off Georgia, numerous specimens.

In most Melanellae showing torsion, the spire is bent either to the right or left; in the present one the bending is in the direction opposite to the plane of the aperture.

\section{MELANELLA STAMINA, new species}

Shell small, slender, white, smooth and polished, flat-sided, acute conic, the apex minute and blunt; shell with about seven flattish whorls; suture distinct, closely appressed, not glazed over, with no visible sculpture, last whorl less than half as long as the shell; the spire straight; base elongately rounded, imperforate; aperture elon- 
gate, narrow, the margins thin, the outer lip slightly convexly produced medially, the inner lip a little raised with no umbilical dimple. Length of shell, 4.75; of aperture, 1.7 ; diameter, $1.25 \mathrm{~mm}$. U. S. Nat. Mus. Cat. No. 108038.

Off Fernandina, many specimens.

Slender and very straight, approaching Strombiformis in form.

MELANELLA PATULA Dall and Simpson

Eulima patula Dall and Simpson, Moll. Porto Rico, p. 413, pl. 57, fig 3, 1901.

Off Georgia, 20 specimens. Porto Rico, in Mayaguez Harbor, 5 specimens.

MELANELLA VERSA, new species

Shell small, transparent whitish with obscure olivaceous nebulosities, adout nine whorls, a minute blunt apex, dextrally wholly arcuate; suture distinct, not glazed over; surface smooth and polished; aperture ovate, posterior commissure acute; outer lip strongly arcuately produced; inner lip short, thick, the base evenly attenuated, imperforate; the last whorl about one-half the whole length. Length, 4.5; diameter, $1.5 \mathrm{~mm}$. U. S. Nat. Mus. Cat. No. 108043.

Off Fernandina, one specimen.

The shell is somewhat discolored by its sojourn on the bottom, but the olivaceous clouding seems normal.

MELANELLA IRA, new species

Shell minute, slender, white, with about nine slightly convéx whorls, the apex minute, rounded; surface polished without sculpture, the suture glazed over; last whorl about one third the whole length in the adult; aperture ovate, the outer lip moderately arcuate, the inner lip callous, slightly raised with a narrow depression behind it; base rounded, slightly produced. Length, 4.6 ; diameter, $1.3 \mathrm{~mm}$. U. S. Nat. Mus. Cat. No. 108036.

Off Fernandina and Georgia, many specimens.

This comes pretty close to the form of Aclis.

\section{MELANELLA PARALLELLA, new species}

Shell small, slender, white, straight, with a slightly irregular minute nucleus and about nine whorls; suture distinct, not glazed over, one or more varical grooves to each whorl; the sides of the whorls are flat, there are also axial feeble irregular wrinkles covering them; the anterior edge of the whorls in the later part of the shell slightly bulging; aperture ovate, body and pillar with a coat of enamel; base rather abruptly rounded, imperforate; a narrow depression behind the inner lip; outer lip very slightly arcuate. Length, 5; of last whorl, 1.5; diameter, $1.2 \mathrm{~mm}$. U. S. Nat. Mus. Cat. No. 108378.

Off Georgia, not rare. 


\section{Genus STROMBIFORMIS Da Costa}

STROMBIFORMIS ELATA, new species

Shell slender, whitish, thin, with a somewhat swollen nucleus and about nine moderately convex whorls; suture distinct, whorls smooth and polished, last whorl less than half the whole length; aperture ovate, a thin callus on the inner lip; base ovately rounded, outer lip arcuately produced. Length, 6.75 ; diameter, 1.6 ; last whorl, 2.5 mm. U. S. Nat. Mus. Cat. No. 108381.

Off Georgia, a dozen dilapidated specimens.

\section{STROMBIFORMIS FUSUS Dall}

Eulima (Liostraca) fusus DALL, Bull. Mus. Comp. Zoöl., vol, 18, p. 329, pl. 19, fig. $11 b ., 1889$.

Off Fernandina, 18 specimens. Off Havana in 400 fathoms, temperature $39.75^{\circ}$ F., Yucatan Strait, 640 fathoms; U. S. S. Blake.

\section{Genus NISO Risso}

\section{NISO MICROFORIS, new species}

Shell small, conic (discolored but probably) white, with no trace of color at periphery or at the varical grooves; whorls flat, about 10 in number, suture distinct; last whorl obscurely carinate at the periphery, base rounded, umbilicus minute and not carinate at the margin; aperture rounded-quadrate, hardly angulate in front. Length, 9.5; diameter, $4 \mathrm{~mm}$. U. S. Nat. Mus. Cat. No. 108374.

Off Georgia, one adult and two young specimens.

This has a smaller and less carinate umbilicus than any other figured species. The young specimens are whitish. The varical grooves are feeble.

\section{Genus ACLIS Lovèn}

ACLIS GEORGIANA, new species

Shell minute, subcylindrical, polished, white, with a blunt apex and about six well rounded whorls; suture distinct, deep, not appressed; sculpture only of faint incremental lines; base rounded, aperture obliquely ovate, the margins thin, the outer lip protractively arcuate medially, the axis imperforate. Length of shell, 3 ; of aperture, 1; diameter, $1 \mathrm{~mm}$. U. S. Nat. Mus. Cat. No. 108020.

Off Fernandina and Georgia, numerous.

This resembles A. bermudensis Dall and Bartsch, but is larger and more cylindrical.

\section{ACLIS DALLI Bartsch}

Aclis dalli Bartsch, Proc. U. S. Nat. Mus., vol. 40, No. 1829, p. 435, pl. 59, fig. 1, May, 1911.

Shell small, slender, acute, translucent white, polished, with about a dozen well rounded whorls, the apex blunt; suture distinct, rather deep, not appressed; sculpture of faint flexuous incremental lines; 
base briefly rounded, aperture rounded, the margin thin, the outer lip flexuous, a minute chink behind the inner lip. Length of shell, 6.7 ; of aperture, 1.0; diameter, $1.6 \mathrm{~mm}$. U. S. Nat. Mus. Cat. No. 108025 .

Off Georgia and Fernandina, very common. Also in 780 fathoms off Cuba; Dr. W. H. Rush.

This appears to be the most common species of the region.

ACLIS LIMATA, new species

Shell small, acute-conic, thin, translucent white, polished, with a minute blunt apex and about seven whorls; suture distinct, closely appressed, not glazed over; later whorls slightly overhanging the succeeding suture; sculpture of very fine close flexuous incremental lines only visible under magnification; base evenly rounded, imperforate; aperture ovate, outer lip produced medially, thin, rounding into the arcuate inner lip. Length of shell, 4 ; of aperture, 0.8 ; diameter, $1.5 \mathrm{~mm}$. U. S. Nat. Mus. Cat. No. 108044.

Off Fernandina, one specimen.

This has much the shape of some of the smaller Melanellas, but the thin shell is more like Aclis.

\section{ACLIS STILIFER, new species}

Shell minute, conic, white, polished, with a small blunt apex and about six moderately rounded whorls, of which the earlier ones are more rapidly attenuated; suture distinct, appressed, not deep or glazed over; sculpture only of faint flexuous incremental lines; aperture rounded-ovate, with a thin margin, a narrow chink behind the inner lip, the base briefly rounded. Length of shell, 2.5; of aperture, 1.2 ; diameter, $1.4 \mathrm{~mm}$. U. S. Nat. Mus. Cat. No. 108024.

Off Georgia and Fernandina, not rare.

Some of the incremental lines are more deeply impressed than others.

ACLIS FERNANDINAE, new species

Shell minute, conical, white, with a very minute blunt smooth nucleus hardly differentiated from the succeeding moderately convex whorls; suture distinct, deep; sculpture only of faint incremental lines, some of which at long intervals are deeper than the rest; surface polished; base rounded; aperture short, ovate, with simple margins; a slight chink behind the inner lip. Length of shell, 2.9; of aperture, 0.5; diameter, $1 \mathrm{~mm}$. U. S. Nat. Mus. Cat. No. 108047.

Off Fernandina, three specimens.

With the form described as typical are others more slender but otherwise entirely similar. This resembles A. stilifer but the increase of the spire is more regular, the last whorl not so conspicuous, and the suture markedly deeper. 
ACLIS PENDATA, new species

Shell small, white, polished, acute-conical, with a minute apical and eight or nine subsequent moderately rounded whorls; suture distinct, not appressed; sculpture only of extremely feeble flexuous incremental lines; base shortly rounded; aperture shortly ovate, the margin thin, the outer lip arcuately produced, the anterior margin of the aperture slightly patulous; the inner lip raised, with a minute umbilical perforation behind it. Length of shell, 5 ; of aperture, 1.3; diameter, $2 \mathrm{~mm}$. U. S. Nat. Mus. Cat. No. 108021.

Off Fernandina and Georgia, 35 specimens.

\section{ACLIS CONULA, new species}

Shell small, smooth, white, conical, with a minute blunt apex and about seven moderately convex whorls; suture distinct, not deep nor appressed; sculpture only of faint incremental lines, some of which at rare intervals are more pronounced than others; aperture shortoval, the margins not thickened, the body without callous deposit; the outer lip protractively arcuate medially; the inner lip concavely arcuate with a minute chink behind it, the base rather abruptly rounded. Length of shell, 3.7; of aperture, 1.1; diameter, $1.7 \mathrm{~mm}$. U. S. Nat. Mus. Cat. No. 108022.

Off Fernandina, one specimen.

\section{ACLIS LATA Dall}

Aclis (supranitida Wood, var.?) lata DALL, Bull. Mus. Comp. Zool,, vol. 18 , p. 324 , pl. 18 , fig. 8, 1889.

Shell small, elongate-conic, white, with a minute blunt apex and about a dozen slightly convex whorls; suture shallow, appressed; sculpture only of oblique irregular incremental lines, somewhat stronger on the early whorls; aperture short, almost rounded, base abruptly rounded; outer lip thin, slightly arcuate; inner lip with a minute perforation behind it. Length of shell, 7.6 to 10.5; of aperture, 1.5 to 2 ; diameter, 2.7 to $3 \mathrm{~mm}$. U. S. Nat. Mus. Cat. No. 108041.

Off Fernandina and Georgia, numerous specimens. Barbados in 100 fathoms, U. S. S. Hassler; type.

\section{ACLIS PYRAMIDA, new species}

Shell small, short-conic, white, smooth, polished, with five and a half moderately rounded whorls; apex blunt, suture well impressed, last whorl about half the length of the shell; base evenly rounded and minutely perforate; aperture subcircular, lips thin, outer lip prominently arcuate forward. Length, 2 ; diameter, $1.1 \mathrm{~mm}$. U. S. Nat. Mus. Cat. No. 108223.

Off Fernandina, one specimen. 


\section{ACLIS TENUIS Verrill}

Aclis tenuis Verrill, Trans. Conn. Acad., vol. 5, p. 528, pl. 58, fig. 19, 1882.

Off Georgia, nine specimens. Off Marthas Vineyard, 100 fathoms, United States Fish Commission.

\section{ACLIS CUBANA Bartsch}

Aclis cubana Bartsch, Proc. U. S. Nat. Mus., vol. 40, No. 1829, p. 435, pl. 59, fig. 2, 1911.

Off Fernandina, 20 specimens. Off Cuba in 780 fathoms mud; Dr. W. H. Rush.

ACLIS RHYSSA, new species

Shell small, slender, subcylindrical, translucent white, polished, with nine or ten well rounded whorls; the apex blunt, the nuclear whorl small and slightly tilted, suture constricted; axial sculpture of numerous (on the last whorl about 15) somewhat sharp wrinkles, strongest at and behind the periphery where they sometimes give an obscurely angulate appearance just behind the middle of the whorl, and are a little retractively flexuous; the strength of these wrinkles varies in different specimens, some of them are nearly smooth on the later whorls; the base is evenly rounded and imperforate; the aperture ovate, with thin margins. Length of type specimen, 6 ; diameter, 1.3 mm. U. S. Nat. Mus. Cat. No. 108389.

Off Georgia, very numerous. Off Fernandina, one specimen.

This species is somewhat like $A$. dalli but more cylindrical and with more constricted suture, while $A$. dalli has no axial sculpture except faint incremental lines.

ACLIS HENDERSONI, new species

Shell small, translucent white, with two transparent apical whorls and seven subsequent whorls; suture deep; early whorls with two peripheral elevated threads, later four, then on the last three whorls the posterior thread becomes a well defined keel at the shoulder while the other threads become obsolete; base well rounded, imperforate; axial sculpture of faint incremental lines; aperture obliquely ovate, the peristome expanded and even somewhat reflected, thin and simple. Length, 4.3; last whorl, 1.7 ; diameter, $1.3 \mathrm{~mm}$. U. S. Nat. Mus. Cat. No. 333465.

Off Fernandina and Georgia, one specimen each.

This recalls A. floridana Bartsch, but is larger and with much more emphatic sculpture. The young shell is spirally threaded over the base and on the last whorl.

\section{Subgenus Amblyspira Dall}

ACLIS (AMBLY SPIRA) IMMACULATA, new species

Shell minute, subcylindrical, polished, white with a blunt apex and about six nearly flat-sided whorls; suture obscure, flatly appressed, 
having the aspect of being overglazed; sculpture only of nearly imperceptible incremental lines; base somewhat prolonged, rounded; aperture ovate, outer lip thin, produced medially, evenly rounded into a short slightly concave inner lip. Length of shell, 3.2 ; of aperture, 0.7; diameter, $1 \mathrm{~mm}$. U. S. Nat. Mus. Cat. No. 108037.

Off Fernandina, numerous.

\section{Genus MUCRONALia A. Adams}

MUCRONALIA MAMMILLATA, new species

Shell spindle-shaped, thin, translucent white, with a minute subcylindrical initial whorl and about three subsequent, moderately convex, smooth, polished whorls, the last of which is much the largest; suture closely appressed; base attenuated; aperture narrow, sublunate, the margins thin, simple, outer lip nearly straight, slightly retractive anteriorly. Length of shell, 4 ; of aperture, 1.5 ; diameter, $1.5 \mathrm{~mm}$. U. S. Nat. Mus. Cat. No. 108040.

Off Fernandina, one specimen.

This has somewhat the form of an Olivella.

\section{MUCRONALIA SUAVA, new species}

Shell small, spindle-shaped, slender, translucent white, with a brownish styliform nucleus of two and about four and a half slightly convex subsequent whorls; suture closely appressed, distinct; sculpture of fairly evident incremental lines; last whorl more than half as long as the shell; base attenuated, imperforate; aperture narrow, margins thin, simple, outer lip nearly straight, anteriorly receding; inner lips slightly raised. Length of shell, 5.5; of aperture, 1.8; diameter, 1.9 mm. U. S. Nat. Mus. Cat. No. 108392.

Off Georgia, three specimens.

This is of the same general type as M. mammillata but is larger, and the transition from the mucro to the normal whorls is less abrupt.

MUCRONALIA ? BULIMULOIDES, new species

Shell much the shape of a slender Bulimulus or Lymnaea, white, translucent, with seven moderately convex whorls, including two slightly brownish nuclear whorls; suture distinct, not deep; surface brilliantly polished, with faint incremental lines; a faint varical groove on each whorl; last whorl more than half as long as the shell $(3.7 \mathrm{~mm}$.); base gently attenuated, imperforate; aperture elongate-oval, outer lip thin, moderately convexly arcuate; inner lip thin, nearly straight, slightly raised, no callus on it or on the body. Length, 6 ; diameter, $2.5 \mathrm{~mm}$. U. S. Nat. Mus. Cat. No. 108382.

Off Georgia, five specimens.

There is some doubt as to the proper place of this shell, as the nuclear whorls are abruptly separated from the others, but otherwise 
the characters agree well with those of Mucronalia, and it seems best to place it tentatively with that group.

\section{Genus STILIFER Broderip}

STILIFER VERRILLI, new species

Shell small, inflated turbinate, white, polished, with a minute styliform apex and about three globose rapidly enlarging whorls; suture appressed, distinct, not deep; sculpture of very faint incremental lines, and a slight wrinkling along the anterior edge of the suture; base imperforate, rounded, aperture ample, outer lip thin, inner lip somewhat thickened. Length, 4 ; diameter, $3.5 \mathrm{~mm}$. U. S. Nat. Mus Cat. No. 108111.

Off Fernandina, one specimen.

At first sight this would be taken for a mutation of S. stimpsoni Verrill, but the second whorl is much smaller than in that species.

The last whorl comprises most of the shell.

\section{STILIFER MINIMA, new species}

Shell minute, turbiniform, thin, white polished, with a minute styliform brownish nucleus of two and about three subsequent inflated whorls; suture very distinct, rather deep; sculpture only of extremely faint incremental lines; base plumply rounded, imperforate; aperture wide, semilunate, the margins thin and sharp. Length of shell, 3 ; of aperture, 1.4; diameter, $1.9 \mathrm{~mm}$. U. S. Nat. Mus. Cat. No. 108039.

Off Fernandina, four specimens.

\section{STILIFER MINUTA, new species}

Shell minute, transparent, thin, with a minute styliform brownish nucleus of about three, and three subsequent whorls; suture distinct, narrowly appressed; surface with faint incremental lines but no other sculpture; the general form is like a short Bulimulus; the last whorl about three-fifths of the whole shell; base rounded; aperture semilunate, the margins thin, the inner lip a little raised but with no indication of an umbilical dimple. Length, 2 ; diameter, $1.7 \mathrm{~mm}$. U.S. Nat. Mus. Cat. No. 108227.

Off Fernandina, one specimen.

This resembles $S$. minima but is smaller and proportionately more globose. It is the smallest species I have seen.

\section{Family PYRAMIDELLIDAE}

This family is well represented in the collection by 24 species, all supposed to be new, but very unequally represented at the two stations. Off Fernandina 19 species and 250 specimens were obtained, but of these 194 specimens represented only 4 species. Off Georgia only 30 specimens of 8 species were obtained. Only 3 species, total$24105-27 \dagger-6$ 
ing 21 specimens, were represented at both stations. Strioturbonilla was the group most numerously represented; there are three Odostomias, and five species representing subordinate groups of the genus Pyramidella.

The species of this family included in this paper have been studied and described by my colleague, Dr. Paul Bartsch, who should be cited as the authority for the specific names.

\section{Genus PYRAMIDELLA Lamarck \\ Subgenus LONGCHaEus Mörch \\ PYRAMIDELLA (LONGCHAEUS), species}

A young specimen of 4.5 whorls, Cat. No. 107927, U.S.N.M., was dredged at United States Bureau of Fisheries Station 2668, in 294 fathoms, sandy bottom, $46.3^{\circ} \mathrm{F}$. bottom temperature, off Fernandina, Fla.

\section{Subgenus Sulcorinella Dall and Bartsch}

\section{PYRAMIDELLA (SULCORINELLA) CAMARA, new species}

Shell elongate-ovate, bluish white with a narrow opaque band a little anterior to the summit of the whorls. Nuclear whorls forming a depressed helicoid spire the axis of which is at right angles to that of the succeeding turns, in the first of which the nuclear spire is deeply immersed, only two-fifths of its tilted edge projecting. Postnuclear whorls flattened, with a concave shoulder at the summit, smooth excepting fine incremental lines and exceedingly fine spiral striations. Suture deeply channeled. Periphery of the last whorl provided with a rather strong narrow keel. The summit of the succeeding turns falls a little anterior to this keel and thus produces the broadly channeled suture. Base short, slightly rounded, narrowly, openly umbilicated, marked like the spire. Aperture rhomboidal; posterior angle obtuse; outer lip thin; inner lip curved, reflected over but not appressed to the base, provided with a strong oblique fold at its insertion.

The type, Cat. No. 108383, U.S.N.M., comes from United States Bureau of Fisheries Station 2415, in 440 fathoms, sandy bottom, $45.6^{\circ}$ bottom temperature, off Georgia. It has five postnuclear whorls and measures. Length, $2.8 \mathrm{~mm}$; diameter, $1.3 \mathrm{~mm}$.

Cat. No. 360168, U.S.N.M., contains two additional specimens from the type locality.

\section{Subgenus Syrnola A. Adams}

\section{PYRAMIDELLA (SYRNOLA) FERNANDINA, new species}

Shell elongate-conic, slender, milk white. Nuclear whorls two and a half, forming a depressed helicoid spire, the axis of which is at right angles to that of the succeeding turns, in the first of which the nuclear spire is about one-third immersed. Postnuclear whorls flattened, 
narrowly shouldered at the summit, marked by incremental lines and exceedingly fine spiral striations only. Suture slightly constricted. Periphery of the last whorl well rounded. Aperture elongate-ovate; posterior angle acute; outer lip thin; inner lip almost vertical, provided with an obsolete fold a little anterior to the insertion of the columella.

The type, Cat. No. 108051, U.S.N.M., comes from United States Bureau of Fisheries Station 2668, in 294 fathoms, sandy bottom, $46.3^{\circ}$ bottom temperature, off Fernandina, Fla. It has nine postnuclear whorls and measures: Length, $6 \mathrm{~mm}$.; diameter, $1.4 \mathrm{~mm}$.

Cat. No. 108065, U.S.N.M., contains 10 additional specimens from the type locality and Cat. No. 108364, U.S.N.M., contains 2 from United States Bureau of Fisheries Station 2415, in 440 fathoms, sandy bottom, $45.6^{\circ}$ bottom temperature, off Georgia .

PYRAMIDELLA (SYRNOLA) FLORIDANA, new species

Shell elongate-conic, cream yellow. Nuclear whorls at least one and a half, forming a very depressed helicoid spire which is obliquely almost half immersed in the first of the succeeding turns. The last nuclear whorl projects materially beyond the outline of the postnuclear spire. Postnuclear whorls slightly rounded, narrowly shouldered at the summit, marked by fine incremental lines and very closely spaced microscopic spiral striations. Suture moderately constricted. Periphery of the last whorl well rounded. Base moderately prolonged, well rounded. Aperture elongate oval; posterior angle obtuse; outer lip thin; inner lip almost straight, reflected over and appressed to the base for about one-third of its length, provided with an obsolete, oblique fold a little anterior to its insertion.

The type, Cat. No. 108056, U.S.N.M., was dredged at United States Bureau of Fisheries Station 2668, in 294 fathoms, sandy bottom $46.3^{\circ}$ bottom temperature, off Fernandina, Fla. It is an immature specimen of 5.5 whorls and measures: Length, $3.5 \mathrm{~mm}$; diameter $1.1 \mathrm{~mm}$.

PYRAMIDELLA (SYRNOLA) GEORGIANA, new species

Shell elongate-ovate, bluish white, semitranslucent. Nuclear whorls very small, immersed in the first of the postnuclear turns, above which the rounded edge of the last volution only projects. Postnuclear whorls well rounded, moderately shouldered at the summit, marked by lines of grow th and fine, closely spaced microscopic spiral striations only. Suture scarcely constricted. Periphery of the last whorl well rounded. Base short, strongly rounded, marked like the spire. Aperture oval; posterior angle acute; outer lip fractured, showing four spiral lirations within, of which two are anterior to the periphery and the other two are about an equal distance posterior to it; inner lip stout, reflected and appressed to the base for half its length and provided with a rather strong fold a little anterior to its insertion. 
The type, Cat. No. 108366, U.S.N.M., comes from United States Bureau of Fisheries Station 2415, 440 fathoms, sandy bottom, $45.6^{\circ}$ bottom temperature, off Georgia. The type has 6.1 postnuclear whorls and measures: Length, $5.2 \mathrm{~mm}$; diameter, $2.2 \mathrm{~mm}$.

Cat. No. 107992, U.S.N.M., contains another specimen from United States Bureau of Fisheries Station 2668 in 294 fathoms, sandy bottom, $46.3^{\circ}$ bottom temperature, off Fernandina, Fla.

\section{Genus TURBONILLA Risso}

Subgenus Ptycheulimella Sacco

\section{TURBONILLA (PTYCHEULIMELLA) HESPERA, new species}

Shell elongate-conic, bluish white. Nuclear whorls two and a half forming a depressed helicoid spire, the axis of which is almost at right angles to that of the suceeding turns, in the first of which the nuclear spire is about one-fourth immersed. The edge of the nuclear spire extends slightly beyond the outline of the postnuclear spire on the left side. Postnuclear whorls rather high between summit and suture, very narrowly shouldered at the summit, the early ones marked by feebly developed, protractively slanting axial ribs, which are broader than the spaces that separate them. They are too ill defined to permit of proper counting. In addition to the obsolete ribs the spire is marked by fine lines of growth and very closely spaced microscopic spiral striations. Periphery of the last whorls strongly rounded. Base very short, inflated, strongly rounded. Aperture broadly oval; posterior angle obtuse; outer lip thin; inner lip almost straight, slender, slightly reflected and appressed to the base for the posterior half of its length, provided with an obsolete fold near its insertion.

The type, Cat. No. 360181, U.S.N.M., comes from United States Bureau of Fisheries Station 2668 in 294 fathoms, sandy bottom, $46.3^{\circ}$ bottom temperature off Fernandina, Fla. It has 10 postnuclear whorls and measures: Length $5.3 \mathrm{~mm}$; diameter, $1.2 \mathrm{~mm}$.

Cat. No. 360169 , U.S.N.M., contains another specimen from the type locality.

\section{TURBONILLA (PTYCHEULIMELLA) MELEA, new species}

Shell small, slender, elongate-conic, milk white. Nuclear whorls two and a half, forming a depressed helicoid spire having its axis at right angles to that of the succeeding turns, in the first of which the nuclear spire is about one-third immersed. Postnuclear whorls flattened, very narrowly shouldered at the summit, marked by somewhat irr egularly developed and spaced obsolete axial ribs, which are so ill defined that they do not permit of counting, and fine lines of growth and closely spaced microscopic striations only. Suture moderately constricted. Periphery of the last whorl well rounded. Base short, well rounded, marked by the fine spiral sculpture only. Aperture 
oval; posterior angle acute; outer lip fractured; inner lip slightly twisted, reflected over and appressed to the $b$ ase for the posterior third of its length, provided with an obsolete fold a little anterior to the insertion of the columella.

The type, Cat. No. 108057, U.S.N.M., comes from United States Bureau of Fisheries Station 2668 in 294 fathoms, sandy bottom, $46.3^{\circ}$ bottom temperature, off Fernandina, Fla. It has 6.7 postnuclear whorls and measures: Length, $3.3 \mathrm{~mm}$., diameter, $0.8 \mathrm{~mm}$.

Cat. No. 360170 , U.S.N.M., contains an additional specimen from the type locality.

\section{Subgenus Strioturbonilla Sacco}

\section{TURBONILLA (STRIOTURBONILLA) NEMEA, new species}

Shell small, elongate-conic, bluish white, semitranslucent. Nuclear whorls two and a half, forming a depressed helicoid spire which has its axis at right angles to that of the succeeding turns, in the first of which it is about one-fifth immersed. The nuclear spire is large and projects beyond the outline of the postnuclear spire on both sides. Postnuclear whorls moderately rounded, almost appressed at the summit, marked by very strong, protractively slanting axial ribs, of which 16 occur upon the first to fifth, 18 upon the sixth and seventh, 20 upon the eighth and last turn. The ribs are strong and extend prominently from the summit to the periphery. They are a little wider than the spaces that separate them. Suture moderately constricted. Periphery of the last whorl well rounded. Base short, well rounded. Spire and base uarked by fine incremental lines and exceedingly fine, wavy spiral striations. Aperture subquadrate; posterior angle obtuse; outer lip thin, showing the external sculpture within; inner lip almost straight, reflected and appressed for its posterior half to the base, provided with an obsolete fold a little anterior to its insertion.

The type, Cat. No. 108363, U.S.N.M., comes from United States Bureau of Fisheries Station 2415 in 440 fathoms, sandy bottom, $45.6^{\circ}$ bottom temperature, off Georgia. It has 10 postnuclear whorls and measures: Length, $4.8 \mathrm{~mm}$.; diameter, $1 \mathrm{~mm}$.

Cat. No. 188277, U.S.N.M., contains nine additional specimens from the type locality.

\section{TURBONILLA (STRIOTURBONILLA) PYRRHA, new species}

Shell elongate-conic, milk white. Nuclear whorls two and a half, forming a depressed helicoid spire, the axis of which is almost at right angles to that of the succeeding turns, in the first of which the nuclear spire is about one-fourth immersed. The nuclear spire extends slightly beyond the outline of the postnuclear spire on the left side. Postnuclear whorls appressed at the summit, moderately rounded, marked 
by rather strong, almost vertical axial ribs, of which 16 occur upon the first and second and 14 upon the remaining whorls. These axial ribs expand slightly near the summit, where they become enfeebled and are separated by spaces about one and a half times as wide as the ribs. Suture moderately constricted. Periphery of the last whorl rounded. Base very short, strongly rounded. Entire surface marked by closely spaced, fine spiral striations, which are best shown in the intercostal spaces. Aperture fractured anteriorly; posterior angle obtuse; inner lip provided with an obsolete fold near its insertion.

The type, Cat. No. 108052, U.S.N.M., comes from United States Bureau of Fisheries Station 2668 in 294 fathoms, sandy bottom, $46.3^{\circ}$ bottom temperature, off Fernandina, Fla. It has nine postnuclear whorls and measures: Length, $3.3 \mathrm{~mm}$.; diameter, $0.7 \mathrm{~mm}$.

TURBONILLA (STRIOTURBONILLA) THEONA, new species.

Shell elongate-conic, bluish white, semi-translucent. Nuclear whorls two and a half, forming a rather large helicoid spire, the axis of which is almost at right angles to that of the succeeding turns, in the first of which the nuclear spire is about one-fifth immersed. Postnuclear whorls moderately rounded, almost appressed at the summit, marked by low, rounded, almost vertical ribs, of which 20 occur upon the first to sixth, 22 upon the seventh and the last whorl. Intercostal spaces but feebly depressed. Suture moderately constricted. Periphery of the last whorl well rounded. Base short, strongly rounded, smooth. The entire surface of the shell is marked by fine lines of growth and very fine microscopic spiral striations. Aperture subquadrate; posterior angle obtuse; outer lip thin, showing the external markings within by transmitted light; inner lip almost straight, reflected over and appressed to the base for about a third of its length, provided with an obsolete fold near its insertion.

The type, Cat. No. 108059, U.S.N.M., comes from United States - Bureau of Fisheries Station 2668 in 294 fathoms, sandy bottom, $46.3^{\circ}$ bottom temperature, off Fernandina, Fla. It has nine postnuclear whorls and measures: Length, $4.6 \mathrm{~mm}$.; diameter, $1.1 \mathrm{~mm}$.

Cat. No. 108063, U.S.N.M., contains about 50 additional specimens from the type locality.

TURBONILLA (STRIOTURBONILLA) ELECTRA, new species

Shell rather large, elongate-conic, bluish white, semitranslucent. Nuclear whorls two and a half, forming a depressed helicoid spire, the axis of which is almost at right angles to that of the succeeding turns, in the first of which the nuclear spire is about one-fourth immersed. Postnuclear whorls moderately well rounded, narrowly shouldered at the summit, marked with slightly protractively slanting axial ribs, which are but feebly developed. On the first turn they are merely 
indicated. On the second 12 are present, 14 on the third to fifth, 16 on the sixth, 18 on the seventh and eighth, while on the last two turns they are quite obsolete. Intercostal spaces shallow, about as broad as the ribs. Sutures moderately constricted. Periphery of the last whorl well rounded, somewhat inflated. Base short, well rounded, slightly inflated. The entire surface of the shell marked by fine incremental lines and microscopic, closely spaced spiral striations. Aperture broadly oval; posterior angle neither acute nor obtuse; outer lip thin, showing the external sculpture within; inner lip slender, curve, reflected over the base for about half its length, provided with an obsolete fold near its insertion.

The type, Cat. No. 108066, U.S.N.M., comes from United States Bureau of Fisheries Station 2668 in 294 fathoms, sandy bottom, $46.3^{\circ}$ bottom temperature, off Fernandina, Fla. It has 10.5 postnuclear whorls and measures: Length, $7 \mathrm{~mm}$.; diameter, $1.8 \mathrm{~mm}$.

Cat. No. 360171, U.S.N.M., contains about 50 additional specimens from the type locality.

\section{T URBONILLA (STRIOTURBONILLA) RHEA, new species}

Shell elongate conic, cream yellow. Nuclear whorls small, two and a half, forming a very depressed helicoid spire, the axis of which is almost at right angles to that of the succeeding turns, in the first of which it is about one-fifth immersed. Postnuclear whorls well rounded, almost appressed at the summit, marked by rather strong, slightly sinuous axial ribs, of which 16 occur upon the first to fifth, 18 upon the sixth, and 20 upon the remaining whorls. Intercostal spaces about as wide as the ribs. Suture rather strongly constricted. Periphery of the last whorl well rounded. Base short, strongly rounded. The entire surface of spire and base marked by fine incremental lines and exceedingly fine microscopic spiral striations. Aperture subquadrate; posterior angle obtuse; outer lip thin, showing the external sculpture within; inner lip thin, somewhat flexuous, reflected over and appressed to the base for half its length, provided with an obsolete fold near its insertion.

The type, Cat. No. 108055, U.S.N.M., comes from United States Bureau of Fisheries Station 2668, in 294 fathoms, sandy bottom, $46.3^{\circ}$ bottom temperature, off Fernandina, Fla. It has 11.5 postnuclear whorls and measures: Length, $6.2 \mathrm{~mm}$.; diameter, $1.3 \mathrm{~mm}$.

Cat. No. 360172 , U.S.N.M., contains about 40 specimens from the type locality.

TURBONILLA (STRIOTURBONILLA) SIRENA, new species

Shell large, robust, broadly elongate conic, milk white. Nuclear whorls two and a half, forming a rather large, depressed helicoid spire, the axis of which is at right angles to that of the succeeding turns, in the first of which it is about one-third immersed. The left side of 
the nuclear spire projects beyond the outline of the postnuclear spire. Postnuclear whorls almost flattened, almost appressed at the summit, marked by very strong, slightly curved, almost vertical axial ribs, of which 16 occur upon the first to fourth, 18 upon the fifth to seventh, 20 upon the eighth, and 22 upon the last whorl. These ribs become slightly flattened and expanded near the summit of the whorls. The intercostal spaces are deep. Suture moderately constricted. Periphery of the last whorl well rounded. Base short, well rounded. The entire surface of the shell marked by rather close incremental lines and rather coarse spiral striations. Aperture subquadrate; posterior angle obtuse; anterior portion of the outer lip fractured; inner lip stout, reflected over and appressed to the base for about half its length, provided with an obsolete fold a little anterior to its insertion.

The type, Cat. No. 108060, U.S.N.M., comes from United States Bureau of Fisheries Station 2668, in 294 fathoms, sandy bottom, $46.3^{\circ}$ bottom temperature, off Fernandina, Fla. It has 9.3 whorls and measures: Length, $7.3 \mathrm{~mm}$.; diameter, $2.1 \mathrm{~mm}$.

Cat. No. 108362, U.S.N.M., contains seven specimens from United States Bureau of Fisheries Station 2415, in 440 fathoms, sandy bottom, $45.6^{\circ}$ bottom temperature, off Georgia.

TURBONILLA (STRIOTÚRBONILLA) LETA, new species

Shell small, pupoid, milk white. Nuclear whorls two and a half, forming a planorboid spire, the axis of which is obliquely placed to that of the succeeding turns, in the first of which the nuclear spire is about one-fourth immersed. Postnuclear whorls flattened, narrowly shouldered at the summit, the first with mere indications of axial ribs, while on the remaining turns they are more strongly developed, though on none prominent. Of these ribs, 12 occur upon the second, 14 upon the third, 16 upon the fourth and the last whorl. These ribs are low and broad and about as wide as the shallow spaces that separate them. Suture moderately constricted. Periphery of the last whorl well rounded. Base rather long, well rounded. The entire surface of spire and base marked by fine incremental lines and numerous closely spaced wavy spiral striations. Aperture oval; posterior angle acute; outer lip thin, showing the external sculpture within; inner lip somewhat curved, reflected and appressed to the base for about half its length and provided with an obsolete fold near its insertion.

The type, Cat. No. 108062, U.S.N.M., comes from United States Bureau of Fisheries Station 2668, in 294 fathoms, sandy bottom, $46.3^{\circ}$ bottom temperature, off Fernandina, Fla. It has 6.1 postnuclear whorls and measures: Length, $3 \mathrm{~mm}$; diameter, $1 \mathrm{~mm}$. 
Cat. No. 360173 , U.S.N.M., contains 14 additional specimens from the type locality.

TURBONILLA (STRIOTURBONILLA) MYIA, new species

Shell large, elongate conic. Nuclear whorls and early postnuclear whorls decollated. The six and a half remaining are well rounded, almost appressed at the summit, crossed by strong, almost vertical axial ribs of which 14 occur upon the first and 16 upon the remaining turns. These ribs become slightly enfeebled and expanded toward the summit. Intercostal spaces about as wide as the ribs, strongly impressed. Suture moderately constricted. Periphery of the last whorl strongly rounded. Base short, strongly rounded. Entire surface of spire and base marked by rather strong lines of growth and numerous moderately strong spiral striations. Aperture subquadrate; posterior angle obtuse; outer lip fractured; inner lip almost straight, stout, reflected over and appressed to the base for about half its length, provided with an obsolete fold a little anterior to its insertion.

The type, Cat. No. 347844, U.S.N.M., comes from United States Bureau of Fisheries Station 2415, in 440 fathoms, sandy bottom, $45.6^{\circ}$ bottom temperature, off Georgia. It consists of the last 6.5 whorls which measure: Length, $7.9 \mathrm{~mm}$.; diameter, $2.3 \mathrm{~mm}$.

Cat. No. 108287, U.S.N.M., contains another specimen from the same locality.

\section{TURBONILLA (STRIOTURBONILLA) ENNA, new species}

Shell slender, elongate-conic, bluish white, semitranslucent. $\mathrm{Nu}-$ clear whorls forming a rather large, depressed helicoid spire, which has two and a half whorls. Postnuclear whorls well rounded, rather high between summit and suture, marked by moderately strong, almost vertical axial ribs, of which 16 occur upon all but the last two turns, which have 18. Intercostal spaces about as wide as the ribs. Suture rather strongly constricted. Periphery of the last whorl well rounded. Base moderately long, well rounded, smooth excepting the incremental lines and fine, closely spaced spiral striations, which are characteristic of both base and spire. Aperture elongate oval; posterior angle obtuse; outer lip thin; inner lip almost straight, reflected over and appressed to the base for about half its length, provided with an obsolete fold a little anterior to its insertion.

The type, Cat. No 360175, U.S.N.M., comes from United States Bureau of Fisheries Station 2668, in 294 fathoms, sandy bottom, $46.3^{\circ}$ bottom temperature, off Fernandina, Fla. It has 8.5 postnuclear whorls, having lost the tip and probably a fraction of the first postnuclear turn, and measures: Length, $4.2 \mathrm{~mm}$.; diameter, $0.9 \mathrm{~mm}$. 
Cat. No. 360176, U.S.N.M., contains a young specimen from the type locality, from which we have described the nuclear characters.

\section{TURBONILLA (STRIOTURBONILLA) IDOTHEA, new species}

Shell small, broadly elongate-conic, white. Nuclear whorls decollated. Postnuclear whorls well rounded, very narrowly shouldered at the summit, marked with strong, slightly protractively slanting axial ribs, of which 16 occur upon all but the last turn, which has 18. Intercostal spaces about one and a half times as wide as the ribs, crossed by two incised spiral lines which are stronger than the rest. One of these is at the periphery and the other about two-fifths between the summit and the periphery anterior to the summit. The space between these two incised lines is crossed by 20 equal and equally spaced spiral striations, and the space between the anterior incised line and the summit by 9 . Suture moderately constricted. Periphery of the last whorl well rounded. Base short, strongly rounded, marked by the feeble continuations of the axial ribs, which evanesce before reaching the middle of the base, and numerous closely spaced wavy spiral striations. Aperture moderately large, subquadrate; posterior angle obtuse; outer lip thin; inner lip almost straight, reflected and appressed to the base for the posterior third of its length, provided with a feeble fold a little anterior to its insertion.

The type, Cat. No. 360177, U.S.N.M., comes from United States Bureau of Fisheries Station 2668, in 294 fathoms, sandy bottom, $46.3^{\circ}$ bottom temperature, off Fernandina, Fla. It has six whorls remaining, having lost the nucleus and a fraction of the first postnuclear whorl, and measures: Length, $3 \mathrm{~mm}$.; diameter, $1 \mathrm{~mm}$.

\section{TURBONILLA (STRIOTURBONILLA) NONICA, new species}

Shell elongate-conic, milk white. Nuclear whorls two and a half, forming a depressed helicoid spire, the axis of which is almost at right angles to that of the succeeding turns, in the first of which the nuclear spire is about one-fourth immersed. Postnuclear whorls tabulately shouldered, well rounded, somewhat constricted at the suture, marked by moderately strong, somewhat curved, retractively slanting axial ribs which are poorly developed on the first whorl, and of which 20 occur upon the second, 22 upon the fourth, 24 upon the fifth, 26 upon the sixth, and 30 upon the last turn. Intercostal spaces about as wide as the ribs, crossed by 34 fine spiral striations which are about equal, except those at the summit, which are finer and more closely spaced. Suture strongly constricted. Periphery of the last whorl inflated. Base short, inflated, marked by the continuations of the axial ribs, which extend to the umbilical chink, and spiral sculpture similar to that of the spire. Aperture oval; posterior angle acute; outer lip thin; inner lip short, reflected over and appressed for two- 
thirds of its length to the base, provided with a weak fold at its insertion.

The type, Cat. No. 108061, U.S.N.M., comes from United States Bureau of Fisheries Station 2668, in 294 fathoms, sandy bottom, $46.3^{\circ}$ bottom temperature, off Fernandina, Fla. It has 7.5 whorls and measures: Length, $4.9 \mathrm{~mm}$.; diameter, $1.5 \mathrm{~mm}$.

\section{Subgenus Pyrgiscus Philippi}

\section{TURBONILLA (PYRGISCUS) CONOMA, new species}

Shell large, very broadly elongate-conic, cream yellow. Nuclear whorls two and a half, forming a depressed helicoid spire, the axis of which is at right angles to that of the succeeding turns, in the first of which is about one-fifth immersed. First postnuclear whorls strongly rounded, inflated, smooth, the rest almost flattened, narrowly shouldered at the summit and crossed by stout, slightly protractively slanting axial ribs, of which 20 occur upon the second, 18 upon the third, 20 upon the fourth, 24 upon the fifth and sixth, and 26 upon the last whorl. These ribs are very broad and low and about twice as wide as the spaces that separate them. The intercostal spaces are marked by 13 subequally spaced incised spiral lines, of which the peripheral one is the strongest. In addition to this the entire surface is marked by numerous fine lines of growth and spiral striations. Periphery of the last whorl well rounded. Base short, well rounded, marked by about 16 incised, fine, irregularly spaced, wavy spiral striations. Aperture large, subquadrate; posterior angle obtuse; outer lip fractured; inner lip almost straight, stout, provided with an obsolete fold a little anterior to its insertion.

The type, Cat. No. 108049, U.S.N.M., comes from United States Bureau of Fisheries Station 2668, in 294 fathoms, sandy bottom, $46.3^{\circ}$ bottom temperature, off Fernandina, Fla. It has 7.5 postnuclear whorls and measures: Length, $5.5 \mathrm{~mm}$; diameter, $2.1 \mathrm{~mm}$.

Cat. No. 360178, U.S.N.M., contains an additional specimen from the type locality.

\section{TURBONILLA (PYRGISCUS) MIONA, new species}

Shell elongate-conic, bluish white. Nuclear whorls two, forming a depressed helicoid spire the axis of which is at right angles to that of the succeeding turns, in the first of which the nuclear spire is about onefourth immersed. Postnuclear whorls well rounded, appressed at the summit, the first almost smooth, the rest marked by strong, slightly protractively slanting, low, rounded axial ribs, of which 20 occur upon the second and third, 18 upon the remaining turns. Intercostal spaces a little narrower than the ribs, crossed by eight incised spiral lines of which the posterior four are grouped in pairs. Suture moderately constricted. Periphery of the last whorl well rounded. Base 
short, strongly rounded, marked by several incised spiral lines near the umbilicus. Aperture short, broadly oval; posterior angle acute; outer lip thin; inner lip almost straight, reflected over and appressed to the base for half its length and provided with a feeble oblique fold near its insertion.

The type, Cat. No. 108361, U.S.N.M., comes from United States Bureau of Fisheries Station 2415, in 440 fathoms, sandy bottom, $45.6^{\circ}$ bottom temperature, off Georgia. It has eight postnuclear whorls and measures: Length, $4.2 \mathrm{n} \mathrm{m}$.; diameter, $1.2 \mathrm{~mm}$.

Cat. No. 360174, U.S.N.M., contains two additional specimens from the type locality.

\section{Subgenus Mormula A. Adams}

\section{TURBONILLA (MORMULA) ANIRA, new species}

Shell broadly conic, white. Nuclear whorls two and a half, helicoid, forming a small spire, the axis of which is at right angles to that of the succeeding turns, in the first of which the nuclear spire is about one-fourth immersed. Postnuclear whorls strongly rounded, marked by strong, well-rounded, somewhat flexuous, slightly protractively slanting axial ribs, of which 22 occur upon the first, 20 upon the second, 18 upon the third, 20 upon the fourth and fifth, 22 upon the sixth and seventh, 24 upon the eighth, and 34 upon the last turn. At regular intervals several of these ribs are gathered into low, rounded varices. Intercostal spaces about one and a half times as wide as the ribs, crossed by the following spiral sculpture: A broad series of impressed pits encircles the whorls about two-fifths of the distance between the summit and periphery anterior to the summit. A peripheral pit about half as strong is present. Between this and the strong anterior pit there are eight incised spiral lines of somewhat varying strength, which divide the space between these two series of pits into subequal areas. Two additional incised lines are anterior to the strong anterior pit, which equal the slender lines anterior to the strong pit, in spacing. The space between the summit and this anterior incised line is crossed by numerous fine spiral striations. On the later turns the first basal pit, which equals the strong pit on the posterior portion of the whorls in width, is present in the suture and the space between this and the peripheral pit is crossed by a fine incised line. Suture moderately constricted. Periphery well rounded. Base short, well rounded, marked by about 12 fine incised spiral lines. Aperture large, broadly oval; posterior angle obtuse; outer lip thin; inner lip slender, reflected but not appressed to the base, provided with an obsolete fold at its insertion.

The type, Cat. No. 108058, U.S.N.M., comes from United States Bureau of Fisheries Station 2668, in 294 fathoms, sandy bottom, $46.3^{\circ}$ 
bottom temperature, off Fernandina, Fla. It has 9.5 postnuclear whorls and measures: Length, $8.3 \mathrm{~mm}$.; diameter, $2.1 \mathrm{~mm}$.

Cat. No. 360179, U.S.N.M., contains 12 additional specimens.

\section{Genus ODOSTOMIA Fleming}

\section{Subgenus Evalea A. Adams}

\section{ODOSTOMIA (EVALEA) FERNANDINA, new species}

Shell moderately large, elongate-ovate, milk white. Nuclear whorls immersed in the first of the postnuclear turns, above which the tilted edge of the last volution projects. Postnuclear whorls narrowly shouldered at the summit, almost flat, marked by incremental lines and very fine spiral striations only. Suture quite strongly constricted. Periphery of the last whorl well rounded. Base long, attenuated, wel! rounded, marked like the spire. Aperture fractured, apparently oval; posterior angle acute; outer lip thin; inner lip stout, reflected over and appressed to the base for almost its entire length as a heavy callus; a rather strong callus covers the parietal wall.

The type, Cat. No. 108053, U.S.N.M., comes from United States Bureau of Fisheries Station 2668, in 294 fathoms, sandy bottom, $46.3^{\circ}$ bottom temperature, off Fernandina, Fla. It has 5.5 postnuclear whorls and measures: Length, $4 \mathrm{~mm}$.; diameter, $1.3 \mathrm{~mm}$.

Cat. No. 108076, U.S.N.M., contains another specimen from the type locality.

ODOSTOMIA (EVALEA) RYCLEA, new species

Shell of medium size, elongate-ovate, yellowish white. Nuclear whorls deeply obliquely immersed in the first of the succeeding turns, above which the tilted edge of the last volution only projects. Postnuclear whorls strongly rounded, very narrowly shouldered at the summit. Suture moderately constricted. Periphery of the last whorl inflated, well rounded. Base moderately long, inflated, narrowly umbilicated. Entire surface of spire and base marked by fine lines of growth and rather coarse spiral striations. The latter are particularly pronounced on the base. Aperture large, oval; posterior angle obtuse; outer lip thin; inner lip somewhat curved, reflected but not appressed to the base, provided with a feeble fold a little anterior to its insertion.

The type, Cat. No. 108365, U.S.N.M., comes from United States Bureau of Fisheries Station 2415, in 440 fathoms, sandy bottom, $45.6^{\circ}$ bottom temperature, off Georgia. It has 4.5 postnuclear whorls and measures: Length, $3 \mathrm{~mm}$.; diameter, $1.5 \mathrm{~mm}$.

ODOSTOMIA (EVALEA) RYALE A, new species

Shell small, ovate, bluish white. Nuclear whorls deeply immersed in the first of the succeeding turns, above which the tilted edge of 
the last turn only projects. Postnuclear whorls well rounded, marked by rather strong, slightly retractively slanting lines of growth and numerous closely spaced fine spiral striations. Periphery obsoletely angulated. Base inflated, narrowly, openly umbilicated, well rounded, marked like the spire. Aperture large, broadly oval; posterior angle obtuse; outer lip thin; inner lip strongly curved, reflected but not appressed to the base, provided with an oblique fold a little anterior to its insertion; parietal wall covered by a thin callus.

The type, Cat. No. 108108, U.S.N.M., comes from Bureau of Fisheries Station 2668, in 294 fathoms, sandy bottom, $46.3^{\circ}$ bottom temperature, off Fernandina, Fla. It has 3.5 whorls and measures: Length, $2.5 \mathrm{~mm}$.; diameter, $1.4 \mathrm{~mm}$.

Cat. No. 360180 , U.S.N.M., contains about 50 additional specimens from the type locality.

\section{Family PEDICULARIIDAE}

\section{Genus PEDICULARIA Swainson}

\section{PEDicula Ria DECUSSATA Gould}

Pedicularia decussata Gould, Proc. Boston Soc. Nat. Hist., vol. 5, p. 127, 1855; Otia, p. 215, 1862.

Pedicularia albida DAlL, Bull. Mus. Comp. Zoöl., vol. 9, p. 39, 1881.

Pedicularia decussata Dall, Bull. Mus. Comp. Zoöl., vol. 18, p. 237, fig. 9a-b, 1889.

Off Fernandina and Georgia, 22 specimens.

Off Havana, in 450 fathoms on Solenosmilia variabilis Dumeril; Pourtalés. Yucatan Strait, in 640 fathoms; Blake expedition.

\section{Family SEGUENZIIDAE}

\section{Genus SEGUENZIA Jeffreys}

SEGUENZIA FLORIDANA, new species

Shell small, white, trochiform, with a minute smooth translucent nucleus of about one whorl, and six subsequent whorls; spiral sculpture at first of one, later two and on the last whorl three sharp carinations, the anterior largest, on which the suture is laid; the base has three or four smaller but similar spirals; axial sculpture of extremely fine silky incremental lines; aperture with a short sulcus near the suture, the outer lip scalloped by the sculpture; the pillar short, twisted, with a prominent tooth anteriorly; base well rounded, imperforate. Height of shell, 5; of last whorl, 2.7; diameter, $4 \mathrm{~mm}$. U. S. Nat. Mus. Cat. No. 108084.

Off Fernandina and Georgia, numerous; and off Cape Florida at United States Fish Commission Station 2644, in 193 fathoms, sand, temperature $43.4^{\circ} \mathrm{F}$. 
This resembles S. monocingulata Seguenza, but is larger, and the sculpture of the base is different.

\section{SEGUENZIA RUSHI, new species}

Shell small, depressed trochoid, with about five whorls; the early whorls have one, the later ones two, the last whorl three spiral keels on the anterior one of which the suture is laid; the base is moderately convex, with a deep funicular umbilicus; it is closely finely spirally threaded, the threads a little coarser near the umbilical margin; in the interspaces between the keels on the spire are very minute close spiral striae; aperture with a very shallow sulcus; the outer lip thin, modified by the sculpture; pillar short, twisted, its termination forming a prominent rounded projection hardly to be called a tooth. Height of shell, 2; diameter, $2.6 \mathrm{~mm}$. U. S. Nat. Mus. Cat. No. 108085 .

Off Fernandina and Georgia, 20 specimens.

This is somewhat like $S$. carinata Watson, but wants the carina and is smaller, perhaps the smallest species yet noted.

\section{Family ALABINIDAE?}

\section{Genus ALABINA Dall}

Finella A. Adams (err. typ. pro Fenella), Ann. Mag. Nat. Hist., ser. 3, vol. 6, p. 332, 1866; type Fenella pupoides A. Adams.

Fenella A. Adams, Ann. Mag. Nat. Hist., ser. 3, vol. 13, p. 40, Jan. 1864.Crosse, Journ. de Conchyl., vol. 16, 1868, p. 46.-A. Adams, Ann. Mag. Nat. Hist., ser. 4, vol. 6, p. 122, Aug. 1870. Not Fenella Westwood, Syn. Gen. Brit. Insects, p. 54, 1840.

Elachista Dall and Bartsch, Nautilus, vol. 15, No. 5, p. 58, Sept.1901.Dall, Moll. Porto Rico, p. 427, Nov. 1901. Not Elachista Treitschke, 1833.

Alabina Dall, Nautilus, vol. 15, No. 11, Mar. 1902, p. 127. Type Bittium cerithidioide Dall.

? Obtortio Hedley, Mem. Austr. Mus., vol. 3, pt. 7, p. 412, Mar. 1899. Type Rissoa pyrrhacme Melvill and Standen.

Styliferina Carpenter, 1864, not A. Adams, 1860.

An examination of specimens of Fenella pupoides received from Arthur Adams shows that the nuclear shell begins with two smooth translucent whorls followed by a single larger more inflated whorl and then spiral sculpture well defined, with no axial sculpture. The other Japanese species agree in this character of nucleus and so does the American type of Alabina. The nucleus of Obtortio pyrrhacme however, as described and figured by Hedley, has strong axial riblets and obviously belongs to a different group, and is not identical with the original Fenella. 


\section{ALABINA CERITHIDIOIDES Dall}

Alaba? cerithidioides Dall, Bull. Mus. Comp. Zoöl., vol. 18, p. 258, 1889. Bittium (Styliferina) cerithidioide Dall, Trans. Wagner Inst., vol. 3, p. 276, pl. 16, fig. 8, 1892.

Bittium (Elachista) cerithidioide Dall, Porto Rico Rept., p. 427, 1901; Nautilus, vol. 15 , p. $58,1901$.

Alabina cerithidioides DALL, Nautilus, vol. 15, No. 11, p. 127, 1902.

Off Georgia, two specimens. Station 2315, off Key West, Fla., in 37 fathoms, coral, United States Fish Commission. Widely spread in the Antilles in moderate depths of water. Mayaguez Harbor, Porto Rico, 25-30 fathoms.

The specimens are probably washed from lesser depths of water.

\section{Family MATHILDIIDAE}

\section{Genus MATHILDA Semper}

\section{MATHILDA GEORGIANA, new species}

Shell small, transiucent white, with an inverted smooth nucleus and seven and a half subsequent whorls; suture distinct, not deep; axial sculpture of numerous rounded threads crossing from suture to suture, nodulous at their intersections with the major spirals, and with much wider interspaces; the incremental lines are not conspicuous; spiral sculpture on the spire of two, and on the last whorl of three, major cords, the former near the periphery with a wide interval between them; there are also fine threads, two behind the posterior cord, on the last whorl one between the peripheral cords and about eight on the flattish imperforate base which is not crossed by the axials except incremental lines; aperture rounded, margin thin, the inner margin with no chink behind it. Length of shell, 9.5 ; of aperture, 2.5 ; diameter, $4.2 \mathrm{~mm}$. U. S. Nat. Mus. Cat. No. 108353.

Off Georgia, in large numbers.

This is one of the commonest forms found at this locality.

An examination of the radula of $M$. diomedae Dall, from Hawaii, shows a close relation of this genus to the Turritellidae.

\section{MATHILDA YUCATECANA Dall}

Mathilda yucatecana DALL, Bull. Mus. Comp. Zoöl., vol. 18, p. 266, pl. 20, fig. 7, 1889.

Shell small, pale brownish fading to white, with an inverted smooth nucleus and nearly six subsequent whorls; suture appressed; whorls well rounded, strongly sculptured; axial sculpture of numerous equal threads with wider interspaces, the threads most visible in the interspaces of the spirals; the sutural region is somewhat constricted; spiral sculpture of (on the spire two, on the last whorl three) strong cords near the periphery, with wider interspaces, more or less angulating 
the whorls, and more or less nodulous at the intersections with the axial sculpture; besides these there are fine threads between the suture and the posterior cord, and also on the base; the reticulation is only conspicuous between the larger cords; base rounded, imperforate; the aperture rounded with simple, not thickened margins. Length of shell, 6.5; of last whorl, 3.3; diameter, $3.3 \mathrm{~mm}$. U. S. Nat. Mus. Cat. No. 108090.

Off Fernandina and Georgia, not rare. Also in 640 fathoms, Yucatan Strait.

\section{MATHILDA LACTEOSA, new species}

Shell small, white, with a pale brownish periostracum, with a smooth inverted nucleus and about six and a half subsequent whorls; suture narrowly appressed, distinct; the whorls rather evenly rounded, the sculpture rather feeble in comparison with the other local species; axial sculpture of numerous slender threads extending from suture to suture, equal and equally distributed (except on the last whorl), with wider interspaces; incremental lines inconspicuous, except on the base; spiral sculpture of (on the first three whorls two, on the later ones three) moderately prominent cords at or near the periphery, and six or eight on the base; these are more or less microscopically pirally striate; there are between and on either side of the peripheral cords smaller spiral threads which form squarish reticulations with the axials; there is no obvious nodulation of the cords; base rounded, imperforate, a minute chink behind the thickened inner lip; aperture rounded, the margins thin, simple. Length of shell, 10; of last whorl, 4.8 ; diameter, $4.5 \mathrm{~mm}$. U. S. Nat. Mus. Cat. No. 333453.

Off Georgia, one specimen.

Near $N$.georgiana but less slender, and with less prominent and slightly different sculpture.

\section{MATHILDA GLOBULIFERA, new species}

Shell small, subconic, white, with an inverted swollen nucleus and about five and a half subsequent whorls; suture distinct, appressed; spiral sculpture of a prominent peripheral cord with one or two smaller ones on each side of it, on the anterior one on the last whorl the suture is laid; the base is nearly smooth; axial sculpture of numerous rather thick threads, slightly concavely arcuate, and extending from suture to suture with narrower interspaces and little reticulate effect; base rounded, imperforate; aperture rounded, with thin margin. Length of shell, 5.2; of last whorl, 3.8; diameter, $2.4 \mathrm{~mm}$. U. S. Nat. Mus. Cat. No. 108087.

Off Fernandina, two specimens.

This species is notable for its relatively very large nucleus and small size. 
Shell small (immature), with a translucent smooth inverted nucleus of a whorl and a half and six subsequent whorls; suture constricted, appressed; axial sculpture on the two earlier normal whorls of closeset small ribs crossing the whorls; spiral sculpture is gradually initiated by (on the following whorls one, on the later whorls two) series of prominent granules developed by spiral grooving, and there is a small plain thread in front of the suture; the base is marginated by a small beaded thread with a minute plain one on each side of it, within this margin it is marked with radial feeble ridges; aperture rectangular with a sharp angulation in front of the very short pillar. Length of shell, 3; of last whorl, 1; diameter, $1.3 \mathrm{~mm}$. U. S. Nat. Mus. Cat. No. 108356.

\section{Off Georgia, one specimen.}

The sculpture is so peculiar that it seemed desirable to describe this specimen in spite of its immaturity.

\section{MATHHLDA AMAEA, new species}

Shell minute, creamy white, with an inverted nucleus and about five and a half well-rounded subturrited subsequent whorls; suture distinct, deep; spiral sculpture of (on the early whorls two, on the later ones three) small cords and another on the last whorl on which the suture is laid, in front of which the base is nearly smooth; all these except the last are obscured by the dense axial sculpture of strong equal and equally spaced threads with narrower interspaces crossing from suture to suture and not giving the aspect of reticulation; base slightly flattened, imperforate; aperture rounded with thin margins. Length of shell, 4.5; of last whorl, 2.5; diameter, $2.3 \mathrm{~mm}$. U. S. Nat. Mus. Cat. No. 108089.

Off Fernandina and Georgia, common.

This except for the nucleus has much the look of the Epitonium to which the name Amaea has been applied.

MATHILDA RUSHII Dall.

Mathilda rushii DALL, Bull. Mus. Comp. Zoöl., vol. 18, p. 267, 1889.

Shell small, slender, subturrited, white, with a minute half immersed nucleus, and about nine subsequent moderately rounded whorls; suture distinct, deep; spiral sculpture of, on the spire two, on the last whorl three very obseure cords near the periphery, on the anterior one of the last whorl the suture is laid, within which the base is nearly smooth; axial sculpture of numerous strong threads, extending from suture to suture with narrower interspaces, almost hiding the spirals which do not nodulate the axials at their intersections; base imperforate, aperture short, rounded, with thin margins. 
Length of shell, 7; of last whorl, 2; diameter, $1.8 \mathrm{~mm}$. U. S. Nat. Mus. Cat. No. 108088.

Off Fernandina and Georgia, seven specimens. Bed of the Gulf Stream in 351 to 465 fathoms.

Named in honor of Dr. W. H. Rush, of the Navy, who made many additions to the fauna of the Florida Strait.

\section{MATHILDA HENDERSONI, new species}

Shell of moderate size, ruddy brown, with a transparent inverted nucleus of one whorl and eight subsequent whorls; suture closely appressed, obscure; spiral sculpture of a very prominent beaded cord overhanging the suture all the way down the spire, on the last whorl another on the margin of the base; between the suture and the cord on the spire are four or five equal close-set undulated threads, and a few fine intercalary threadlets; within the margin of the base are four or five similar threads; the space covered by this threading on the spire is constricted and that on the base flattish; axial sculpture of inconspicuous incremental lines; base imperforate, aperture rounded, the outer lip crenulate by the sculpture, thin, simple, the pillar lip short, slightly reflected. Length of shell, 10; of last whorl, 4.5; diameter, $4.5 \mathrm{~mm}$. U. S. Nat. Mus. Cat. No. 333468.

Off Fowey Light, Florida coast, in 25 fathoms; J. B. Henderson, jr. Also Turtle Harbor, Fla., in 50 fathoms; Dr. W. H. Rush.

This remarkable and very characteristic species is named in honor of our late colleague, and comes from the same general area as the other species here described, though known so far from a lesser depth.

\section{Genus TUBA Lea}

\section{TUBA JEFFREYSI Dall}

Tuba jeffreysi Dald, Bull. Mus. Comp. Zoöl., vol. 18, p. 268, 1889.

Shell small, short, white, with an inverted smooth nucleus of one, and four subsequent whorls; suture distinct, deep; axial sculpture of numerous thin sharp lamellae crossing the whorls (including the base) with wider interspaces; spiral sculpture of two strong cords near the periphery, behind the posterior cord are two smaller ones between it and the preceding suture, and on the last whorl another on which the suture is laid; on the base are four more, all with wider interspaces reticulated by the axials but not nodulate at the intersections; on the last whorl a fine spiral thread occurs in some of the interspaces; base evenly rounded; aperture subcircular, with thin margins; behind the arcuate inner lip is a very narrow umbilical perforation. Length of shell, 6 ; of the last whorl, 4 ; diameter, $4 \mathrm{~mm}$. U. S. Nat. Mus. Cat. No. 108086.

Off Fernandina, 10 specimens. 


\section{Family TURRITELLIDAE}

\section{Genus TURRITELLOPSIS G. O. Sars}

TURRITELLOPSIS FLORIDANA, new species

Shell minute, white, slender, with a smooth obliquely set nucleus of a whorl and a half and 8 well-rounded subsequent whorls; suture distinct, appressed; a space in front of the suture is smooth, beyond it are (on the early whorls 2 , later 3 , and on the last whorl 4) small simple equal and equally distributed threads with wider interspaces; the rounded base is smooth; axial sculpture of faint incremental lines and occasional indications of resting stages on the spire; base imperforate, aperture ovate, the outer lip thin, sharp, crenulated by the sculpture. Length, 2.6; diameter, $1 \mathrm{~mm}$. U. S. Nat. Mus. Cat. No. 323856 .

Off Fernandina, one specimen. Gulf of Mexico, off Cape San Blas, in 169 fathoms, at United States Bureau of Fisheries Station 2400; one specimen (type).

This is almost a replica in miniature of $T$. acicula Stimpson, but is more cylindrical and more regularly sculptured.

\section{Family TRIPHORIDAE}

\section{Genus TRIPHORA Blainville}

No species of typical Triphora occurs in the collection, but the genus is represented by numerous specimens belonging to two subgenera. These specimens however are rarely in perfect condition, most of them are more or less stained with manganese oxide and not over 1 in 100 retains the complete adult aperture. It is a curious fact that nevertheless in nearly half the individuals the smooth frail swollen protoconch is well preserved. Many of the specimens have the sculpture worn, which often greatly alters its appearance. Quite a number have been drilled by some carnivorous gastropod, which one would think must have been poorly repaid for its labor. All the species present the well defined aspect of deep sea forms.

\section{Subgenus BIForina Bucquoy, Dautzenberg, and Dollfus}

\section{TRIPHORA (BIFORINA) CARACCA, new species}

Shell small, with 3 brown nuclear and 16 or more subsequent whitish whorls; form acute conical with flattish sides; suture obscure but its situation emphasized by the adjacent beaded cords; spiral sculpture of 2 strong prominently beaded cords with a small slightly undulated simple thread between them; there are also extremely fine close striae over the surface, only visible under magnification; on the anterior cord of ths sixteenth whorl there are 17 beads; the base of the immature shell has a thin but rounded 
edge which is buried in the suture; the base is nearly flat with a faint groove near the periphery and marked by flexuous radiating incremental lines; the pillar is short and the aperture subrectangular; there is no axial sculpture except incremental lines, and the beads are not arranged so as to give the effect of axial ribbing; on the early whorls the sculpture is smaller but similar; the nucleus may include beside the protoconch, which is smooth, 2 or sometimes 3 larval whorls. In the present specimens the protoconch and larval whorls have been worn smooth (if they originally had sculpture); the nepionic whorl shows an undulated smooth thread between two minutely beaded threads. Length of 16 whorls and nucleus, 8; maximum diameter, 2 mm. U. S. Nat. Mus. Cat. No. 108343.

Off Georgia, three specimens.

TRIPHORA (BIFORINA) GEORGIANA, new species

Shell small, whitish, acute conic, straight sided, with a br own nucleus consisting of a smooth protoconch and 2 succeeding whorls sculptured with 2 equal spiral threads, and numerous finer retractively flexuous axial threadlets; these are succeeded by 15 slowly increasing flattish whorls; spiral sculpture of 2 subequal prominently beaded cords with 1 smaller undulated thread in front of them, which is the periphery of the base; there are also fine spiral striae visible under magnification in the interspaces; there is no axial sculpture except incremental lines, but the beads on the 2 cords are arranged in axially linked pairs which can be followed up the spire and give it a partially ribbed aspect; the axial lines of beads make about half a revolution around the spire; the base of the immature shell is flattish, with flexuous incremental lines and a sharp groove just inside the periphery, the canal is very short and slightly twisted. Length of nucleus and 15 whorls, 7.5; maximum diameter, $15 \mathrm{~mm}$. U. S. Nat. Mus. Cat. No. 333516.

Off Georgia, six specimens.

There are 15 beads on the anterior cord of the last whorl.

\section{TRIPHORA (BIFORINA) INDIGENA, new species}

Shell small, whitish, with a brown nucleus consisting of the protoconch and 3 larval whorls, and 13 or more subsequent whorls; the spire is acute conical, the sides nearly straight, but the whorls slightly convex; the larval whorls are sculptured as in the preceding species; the adult whorls are spirally sculptured by two beaded cords with a smooth threadlet in front of them and a row of separate slightly smaller beads between the posterior cord and the preceding suture; there are 16 beads on the anterior cord of the penultimate whorl; these beads occur at the intersections of the cords with the same number of retractively oblique flattish narrow riblets with subequal 
interspaces, the series of which may be followed up the spire which they about one quarter encircle; the last whorl in the type specimen is partially preserved, except the outer lip of the aperture, and is smooth on the rounded base except for flexuous incremental lines, with a very short canal and a trace of the narrow sutural sulcus. Length of 13 whorls, 7 ; maximum diameter, $1.6 \mathrm{~mm}$. U.S. Nat. Mus. Cat. No. 108345.

Off Georgia, two specimens.

A third species much larger than either of the preceding is indicated by fragments from off Fernandina, with three oblique rows of beads connected by rather sharp riblets in the later whorls, the posterior row splitting into two smaller spirals near the adult stage. The shell is thinner and more fragile than either of the others, and the latest whorl preserved has an axial length of 2 and a maximum diameter of $3 \mathrm{~mm}$. U. S. Nat. Mus. Cat. No. 108079.

Subgenus Strobiligera Dall, $1924^{3}$

TRIPHORA (STROBILIGERA) POMPONA, new species

Shell small, white, slender, with a smooth inflated white protoconch of a whorl and a half, directly followed by 21 or more whorls of the adult sculpture; form acute conic, straight sided, the suture not constricted; spiral sculpture of a strong beaded cord at the periphery of the whorl and a similar one in front of it, the summits of the beads subcarinate; behind the posterior cord and between it and the preceding suture are two or three hardly undulated simple threadlets; in front of the anterior cord is an inconspicuous thread which is the periphery of the base and more or less obscured by the.succeeding whorl; the beads on the two cords are obliquely linked in pairs by an axial ridge, and the series of pairs, though not conspicuous, may be followed up the spire; the axial sculpture otherwise is chiefly incremental; the immature base is flattish with flexuous incremental lines and a sharp spiral thread just inside the peripheral margin; the canal is very short and slightly recurved. Lengths of the nucleus and 20 whorls, 15 ; maximum diameter, $2.5 \mathrm{~mm}$. U.S. Nat. Mus. Cat. No. 108339.

Off Georgia, very numerous, but mostly in poor condition. The inflated protoconch differs considerably in size, some being much larger than others, one specimen having a diameter 50 per cent greater than the next succeeding whorl, while others exceed that whorl very little. A larger but imperfect specimen measures about $20 \mathrm{~mm}$. in length.

A variety (?) with exactly the same type and arrangement of sculpture, but the beading less prominent and the shell more slender and compact, measures $10 \mathrm{~mm}$. for 15 whorls, and has a maximum dia-

3 Type Triphora ibex Dall (1889). Antilles. See Proc. Biol. Soc. Wash., vol. 37, p. 89, Feb. 21, 1924. 
meter of $1.75 \mathrm{~mm}$. U.S. Nat. Mus. Cat. No. 333517. It may take the varietal name of dinea.

TRIPHORA (STROBILIGERA) GAESONA, new species

Shell slender, white, acute, straight sided, except that the anterior edge of the whorls slightly overhangs the succeeding suture; protoconch white, smooth, swollen, comprising about 2 turns, with 16 or more subsequent whorls; spiral sculpture not prominent, including 2 flattish threads between the periphery and the succeeding suture with the peripheral edge of the base forming a simple thread at the suture; the incremental lines though very fine are rather evident, and there are very fine spiral striae in the interspaces; the whorls between the periphery and the preceding suture are slightly excavated; the base is flattish with flexuous incremental lines and a spiral groove near the outer edge, the canal is very short, with a callous deposit but no sulcus where the inner lip joins the body; the outer lip is defective in the specimen. Length of whole shell of 16 whorls, 9 ; maximum diameter, $1.8 \mathrm{~mm}$. U.S. Nat. Mus. Cat. No. 108341.

Off Georgia; a worn but larger specimen measures 12 by $2 \mathrm{~mm}$. without the protoconch.

TRIPHORA (STROBILIGERA) ENOPLA, new species

Shell slender, cylindrical, white, with an inflated protoconch of a whorl and a half and about 18 subsequent whorls; suture distinct, not channeled; spiral sculpture of 2 equal and equally spaced beaded cords with the prominent beads feebly linked in pairs by low axial ridges, not arranged in continuous series up the spire; other axial sculpture of faint incremental lines, more prominent on the moderately rounded base; on the base within the edge are 2 strong minutely crenulated spiral cords; aperture ovate, a rather heavy callus on the pillar, the sutural sulcus shallow and inconspicuous, the outer lip thin, the canal very short. Length, 11.5; maximum diameter, $2 \mathrm{~mm}$. U. S. Nat. Mus. Cat. No. 108074.

Off Fernandina, six specimens and fragments.

The cylindrical form is very marked, as well as the prominence of the beads, of which on the penultimate whorl there are about 18 .

TRIPHORA (STROBILIGERA) METEORA, new species

Shell small, slender, white, acute conical, with a conspicuously inflated smooth protoconch of 2 whorls and 12 subsequent whorls; suture obscure, rather oblique; spiral sculpture, on the earlier whorls of 2, later of 3 beaded cords, the posterior cord less prominent, the 2 anterior equal, the beads more or less linked in pairs by inconspicuous axial ridges, but not serially continuous up the spire; the beads are prominent, rather close-set and the interspaces very narrow; there are about 18 beads on the anterior cord of the penultimate whorl; the (immature) base is flattish with a fine groove just inside the edge, 
and feebly marked by flexuous incremental lines; the canal is very short, the adult aperture defective. Length, 9 ; maximum diameter, $2 \mathrm{~mm}$. U. S. Nat. Mus. Cat. No. 108081.

Off Fernandina, eight specimens.

The obliquity of the whorls and the much inflated protoconch are the most conspicuous features of this species.

TRIPHORA (STROBILIGERA) COMPSA, new species

Shell slender, white, conic, the nucleus deficient, with 12 remaining subsequent whorls; suture marked with a fine undulate thread which is the edge of the base; spiral sculpture of 2 prominent beaded cords, a carina running over the tops of the beads which are not axially paired, the interspaces between the cords forming a series of rounded pits; in front of the suture there is a very small, undulated thread, sometimes doubled; in addition there are microscopic spiral striae over the surface; the immature base is flattish, with flexuous radiating incremental lines, and a single sharp groove just inside the margin; the base in the adult is less flat, with four spiral flattened cords covering nearly the whole surface; the canal is short, the axis retains a purplish tint, the outer lip is defective. Length, 12; maximum diameter, $3.3 \mathrm{~mm}$. U. S. Nat. Mus. Cat. No. 333518 .

Off Georgia, two specimens.

TRIPHORA (STROBILIGERA) SENTOMA, new species

Shell elongate, subcylindrical, white, straight sided, the nucleus lost, 17 to 24 whorls remaining but still immature; spiral sculpture of 2 low flattened cords, faintly undulated, one at the periphery of the whorl, the other in front of it, the suture linear with a minute threadlet on each side of it, the interspaces shallow; axial sculpture of faint incremental lines; immature base flat with flexuous radiating lines and a shallow groove inside the outer edge; canal short. Length, about 28; maximum diameter, $3.5 \mathrm{~mm}$. U. S. Nat. Mus. Cat. No. 108072 .

Off Fernandina, two specimens and other fragments.

One of the fragments has a smooth protoconch of a whorl and a half. The total measurement of length is obtained by piecing together fragmentary specimens.

There are two or three other species indicated by specimens too imperfect to serve as a basis for formal description.

\section{Family CERITHIOPSIDAE}

\section{Genus CERITHIOPSIS Forbes and Hanley}

CERITHIOPSIS GEORGIANA, new species

Shell slender, acute with 4 subcylindrical smooth nuclear whorls, the last one merging gradually into the adult sculpture, which continues for about 14 moderately rounded whorls; suture distinct, not 
deep; axial sculpture of (on the last whorl about 16) uniform vertical threads with subequal interspaces; the spiral sculpture consists of an undulate thread at the suture, and another at the margin of the base, and two stronger ones near the periphery; the intersections are not nodose; the reticulations are deep and square, the base is flattish with only flexuous incremental lines inside the marginal thread. Length, 7; diameter, 1.8 mm. U. S. Nat. Mus. Cat. No. 329358.

Off Georgia, eight specimens.

This is the only species of typical Cerithiopsis obtained from these dredgings, unless $C$. eliza be considered one.

Judging from its smooth styliform nucleus, the type of Triforis Deshayes (T. plicata) belongs in this family and not in the group to which Triphora Blainville is referred.

\section{Subgenus LASKeya Iredale}

Eumeta Mörch, Faunula Moll. Islandiae, Vid. Medd., p. 208, 1868; sole example Turritella costulata Moller=Eumeta arctica Mörch. Not Eumeta Walker, 1855, Lepidoptera.

Laskeya Iredale, Proc. Mal. Soc. London, vol. 13, p. 30, Aug., 1918.

This subgenus is characterized conchologically by its short blunt nucleus, as compared with the styliform nucleus of typical Cerithiopsis, and its strong axial ribbing. Fischer adds that the cusps of the uncini are finely denticulate.

The nucleus of the typical species is small and smooth, not exceeding one and a half whorls, and the succeeding nepionic whorl has extremely fine hair-like axial ribbing, followed by the adult sculpture.

The deep water forms described in this paper have a swollen nucleus, usually of greater diameter than the succeeding nepionic whorl, and the latter is usually axially ribbed, with or without spiral lines. While this peculiar nucleus is in my opinion the result of its deep-water environment (found in a great variety of genera from deep water) it seems not to occur in all the deep water Cerithiopsides, some of which retain the styliform nucleus, so it seems tentatively advisable to gather the groups with the swollen nuclei into a special section.

\section{Section ONCHODIA Dall, 1924}

\section{LASKEYA (ONCKODIA) BENTHICA Dall *}

Shell glassy white, with one swollen smooth nuclear whorl followed by one nepionic whorl with retractively angular small riblets with very fine spiral striae in the interspaces, succeeded by seven whorls with the adult sculpture; suture distinct, appressed, slightly constricted; axial sculpture of (on the last whorl 14) stout low, rounded ribs with

4 Sae Proc. Biol. Soc. Wash., vol. 37, p. 89, Feb. 21, 1921. The present species is the type of the section. $24105-27 \dagger \longrightarrow 7$ 
subequal interspaces, somewhat obscured by the spiral sculpture; on the spire the spirals comprise two cords, the anterior stronger, forming at the intersections two rows of beads, the anterior row prominent and larger; there is also a fine simple thread at the margin of the base, in front of which the suture is laid and sometimes an intercalary thread at the periphery; the last whorl has three feebler cords becoming obsolete; the base convex with two or three simple spiral threads; aperture subquadrate, lip simple, the pillar very short and twisted, the canal short. Height, 6 ; diameter, $1.8 \mathrm{~mm}$. U. S. Nat. Mus. Cat. No. 108344.

Off Georgia, many specimens.

\section{LASKEYA (ONCHODIA) MERIDA, new species}

Shell (not quite mature) with a swollen nuclear whorl, followed by a nepionic whorl with feeble, nearly vertical riblets, succeeded by 6 whorls with the adult sculpture; suture distinct; spiral sculpture of (on the early whorls 2, on the later 3) small cords, the peripheral stronger, all moderately nodulating the ribs, 2 fine simple threads at the edge of the moderately convex base, which later are covered in the suture; axial sculpture of (on the last whorl 17) slender slightly protractively oblique ribs with subequal or wider interspaces, cut by the spirals into subequal nodulations; aperture subquadrate, lip thin, pillar slender, short. Height, 3.6 ; diameter, $1.3 \mathrm{~mm}$. U. S. Nat. Mus. Cat. No. 108075.

Off Fernandina, nine specimens.

LASKEYA (ONCHODIA) SERINA, new species

Shell not quite adult, white, with one swollen nuclear and one nepionic whorl, both somewhat worn, and seven subsequent whorls; general sculpture like that of $L$. benthica but more delicate, the ribs finer and more numerous, the suture more constricted; there is a fine crenulate thread at the edge of the flattish base, against which the suture is laid; the two peripheral spirals connected by the vertical ribs give the effect in profile of a flattish broad band encircling the whorls; aperture rounded, pillar short. Height, 4.5; diameter, 1.6 mm. U. S. Nat. Mus. Cat. No. 329380.

Off Georgia, five specimens; off Fernandina three specimens.

\section{LASKEYA (ONCHODIA) DOCATA, new species}

Shell very slender, with one swollen smooth nuclear and one nepionic whorl with feeble nearly vertical riblets, succeeded by 10 whorls with adult sculpture; suture constricted, appressed; last whorl with about 15 vertical ribs with subequal or wider interspaces; the early whorls have 2 peripheral spiral cords and a thread at the suture, later the thread becomes undulate and larger, and the last whorl has 4 spirals; the cords are stronger than the ribs, minutely nodose at the 
intersections and with the ribs form a pretty regular reticulum; the cord near the somewhat convex base is undulate; the base is smooth and flattish, the canal very short, the aperture rounded. Height, 6; diameter, $1.3 \mathrm{~mm}$. U. S. Nat. Mus. Cat. No. 108348.

Off Georgia, one specimen.

\section{LASKEYA (ONCHODIA) ARGENTEA, new species}

Shell small, silvery white, with one smooth swollen nuclear and one nepionic whorl with small arcuate riblets, succeeded by 10 rather flatsided adult whorls; suture distinct, not constricted, a slight overhang to the preceding whorl; axial sculpture of (on the last whorl about 15) narrow, close-set, protractively oblique riblets; the periphery of the whorls is somewhat anterior; spiral sculpture of 3 small threads, the posterior thread less prominent, all minutely nodulous at the intersections; sculpture becoming obsolete on the last whorl; base smooth and rounded, canal short. Height, 5.5; diameter, $1.4 \mathrm{~mm}$. U. S. Nat. Mus. Cat. No. 333474.

\section{Off Georgia, 20 specimens.}

A variety is more slender, with the ribs concavely arcuate. U.S. Nat. Mus. Cat. No. 333475; off Georgia, six specimens.

Another variety (?) from the same locality has the anterior spiral prominent, the sides of the whorl more flattish and sloping. U. S. Nat. Mus. Cat. No. 333476, one specimen.

\section{LASKEYA (ONCHODIA) DECORA, new species}

Shell small, whitish, with a small smooth nucleus and 1 nepionic whorl with small arcuate ribs, succeeded by 12 flattish whorls with adult sculpture; suture distinct, closely appressed, on a few of the late whorls the space in front of it is more or less excavated; on the early whorls are many feeble oblique riblets; these become gradually obsolete on the later whorls which show only incremental axial lines; spiral sculpture increases in strength with age, on the early whorls, there are 2 on the later ones 3 subequal not very prominent spirals, beside a finer thread in front of the suture and 1 at the margin of the base; all more or less minutely crenulate; there are also some fine spiral striae in the interspaces; the base is flattish with flexuous incremental lines; aperture small, subquadrate; canal short, markedly recurved. Height, 7 ; diameter, $1.8 \mathrm{~mm}$. U. S. Nat. Mus. Cat. No. 333477.

Off Georgia, two specimens.

The sculpture on this species is more condensed and finer than on either of the preceding species.

\section{LASKEYA (ONCHODIA) ALTHEA, new species}

Shell acute, elongate conic, shining white, with a smooth glassy nuclear whorl, the nepionic whorl with strong, slightly arcuate ribs, 
followed by 9 whorls with adult sculpture; suture distinct, appressed, somewhat constricted; whorls convex; axial sculpture of numerous (on the last whorl 24) retractively arcuate narrow ribs with subequal interspaces; spiral sculpture of narrow threads, 1 at the suture, 2 near the periphery, and in the adult 2 at the margin of the base; the intersections are slightly angular, not nodulous; base smooth except for arcuate incremental lines, and a little concave; aperture squarish, lip thin, pillar thin, twisted, the edge obliquely attenuated, not prominent. Height, 8.5 ; diameter, $2.7 \mathrm{~mm}$. U. S. Nat. Mus. Cat. 108077.

Off Fernandina, not rare.

\section{LASKEYA (ONCHODIA) ELIMA, new species}

Shell whitish, glossy, conic, with 1 low smooth swollen nuclear and 1 nepionic whorl with feeble axial ribbing, followed by about 8 whorls rather feebly sculptured, with the periphery nearer the succeeding suture; suture distinct, deeper between the later whorls, closely appressed; whorls moderately convex; axial sculpture of (on the last whorl about 20) narrow slightly arcuate low ribs with wider interspaces; also more or less obvious incremental lines continued in an arcuate manner over the smooth rounded base; spiral sculpture of 1 undulated thread near the suture, then a wide spirally finely striated space without threads, then 2 threads near the periphery, and 2 plain minor threads near the margin of the base, 1 of which appears on the spire behind the suture; the intersections are not nodulous, and the sculpture is more feeble on some specimens than on others; aperture rounded, lip thin, the pillar short, slender, twisted. Height, 7; diameter, $2.3 \mathrm{~mm}$. U. S. Nat. Mus. Cat. No. 108349.

Off Georgia, six specimens.

\section{LASKEYA (ONCHODIA) ELSA, new species}

Shell small, slender, whitish, with 1 small smooth inflated nuclear and 2 nepionic whorls, the latter with 2 peripheral spirals crossed by numerous close fine axial threads, and succeeded by 8 moderately rounded whorls with adult sculpture; suture distinct; spiral sculpture of a small spiral cord at the suture, 2 near the periphery, and 1 at the edge of the base on which the suture is laid; axial sculpture of (on the last whorl 16) narrow riblets with wider interspaces, forming an open reticulum, not nodulous at the intersections; the base is smooth except for flexuous incremental lines; aperture rounded, lip thin, pillar short, attenuated in front; canal very short and recurved. Height, 4.7; diameter, 1.6 mm. U. S. Nat. Mus. No. 108347.

Off Georgia, five specimens.

The nucleus of this and the following speci es differs from most of the preceding forms in adding spir al threads to the sculpture of the nepionic part. 


\section{LASKEY (ONCHODIA) APICINA, new species}

Shell small, whitish, elongate conical, with a smooth nuclear whorl in which the apex is small and upturned, and the nepionic part with 1 feeble anterior spiral thread, a few fine spiral striae, and many slightly arcuate small axial riblets; there are 7 succeeding well-rounded whorls; suture distinct; axial sculpture of (on the last whorl 16) narrow vertical ribs with subequal interspaces, the incremental lines not obvious except on the base; spiral sculpture on the last whorl of 1 plain thread at the suture, next to it 2 stronger nodulose threads, then near the periphery 1 more strongly nodose, then a fine thread behind the succeeding suture, 1 of 2 of which the anterior is covered by the following whorl; the base is convex, with 2 threads at the margin and between them and the axis a smooth space; aperture rounded, lip thin, somewhat expanded; pillar very short, attenuated in front. Height 5.5; diameter, 2 mm. U. S. Nat. Mus. Cat. No. 347852.

Off Georgia, two specimens.

\section{LASKEYA (ONCHODIA) HONORA, new species}

Shell small, slender, acute, with 2 glassy nuclear and 1 nepionic whorl carrying 2 spiral lines, followed by 11 whorls with adult sculpture; suture distinct, whorls flattish; spiral sculpture of a small undulate cord in front of the suture, 2 stronger nodulose cords near the periphery, and a plain thread at the margin of the base, which is covered by the suture; axial sculpture of (on the last whorl about 20) narrow ribs more or less hidden under the spirals and with narrower interspaces; base convex, smooth except for incremental lines; aperture rounded, the pillar slender, twisted; the canal short, recurved. Height, 7.5; diameter, 1 mm. U. S. Nat. Mus. No. 329360.

Off Georgia, one specimen.

\section{LASKEYA (ONCHODIA) ELIZA, new species}

Shell small, slender, whitish, with 2 smooth nuclear and 1 nepionic whorl, the latter gradually merging into the adult sculpture of the 7 succeeding well-rounded whorls; suture distinct, not deep; spiral sculpture of a small undulate thread at the suture, 2 stronger nodulose cords near the periphery, and a fine thread at the margin of the base which later is covered by the suture; axial sculpture of (on the last whorl about 12) obscure riblets with narrower interspaces, chiefly indicated by the nodules on the spiral cords; aperture defective, but apparently rounded, pillar slender, not markedly twisted, nearly straight. Height, 3.6; diameter, $1 \mathrm{~mm}$. U. S. Nat. Mus. Cat. No. 108346.

Off Georgia, two specimens.

One of the specimens has two and the other only one smooth nuclear whorl, due perhaps to the longer persistence of the larval stage in the former. 


\section{LASKEYA (ONCHODIA) PETALA, new species}

Shell small, slender, acute, whitish, with 1 glassy swollen nuclear whorl, and 1 nepionic whorl with fine vertical riblets with wider interspaces, succeeded by 12 flat-sided whorls with adult sculpture; suture closely appressed, inconspicuous; the sculpture consists of 3 minutely crenate spirals intersected by fine inconspicuous axial threads, not forming ribs; the sides of the spire are flattish, the base is only slightly convex, smooth except for flexuous incremental lines; the aperture is subquadrate, the pillar short and strongly twisted, the outer edge prominent like a plait. Height, 5; diameter, $1.1 \mathrm{~mm}$. U. S. Nat. Mus. Cat. No. 108350.

Off Georgia, not uncommon.

The conspicuous edge of the twisted pillar is the most obvious character of this species. Some of the less perfect specimens are larger than the one serving as type.

\section{LASKEYA (ONCHODIA) LEIPHA, new species}

Shell small, slender, whitish, with a translucent white inflated nucleus of a whorl and a half, and 12 or more slightly convex subsequent whorls; suture distinct, slightly constricted; axial sculpture of (on the last whorl about 15) equal, nearly straight smooth riblets, with equal or slightly wider interspaces extending from suture to suture; spiral sculpture obscure, of numerous fine striae and on the later whorls two or three small threads, of which one on each side of the periphery is more prominent; base moderately rounded, smooth except for incremental lines, the margin almost carinate, while the ribs stop abruptly behind it; aperture rounded quadrate, canal short. Length of largest specimens 10 ; maximum diameter, $2 \mathrm{~mm}$. U. S. Nat. Mus. Cat. No. 108360.

Off Georgia and Fernandina, about 20 specimens.

Except for its swollen and dextral nucleus, this species closely resembles a Chemnitzia.

\section{Subgenus STILUS Jeffreys}

Stilus Jefrreys, Proc. Zool. Soc. London, for 1885, p. 52. Type Stilus insignis Jeffreys, Proc. Zool. Soc. London, for 1885 , p. 52, pl. 6, figs. 1, $1 a$, 1b, 1885. North Atlantic.

The characteristic of this genus is the slender pointed apex of the larval whorl. It was regarded as a genus by Jeffreys but, as I find in Laskeya apicina a stage intermediate between typical Stilus and Laskeya, I have preferred to regard the group as subgeneric.

\section{STILUS VITREUS, new species}

Shell small, vitreous white, with an apical short upturned spur seated on a turban-shaped nepionic whorl, larger than the succeeding whorl, and sculptured with about 14 strong axial ribs; there are 9 well 
rounded subsequent whorls with adult sculpture; suture deep, with a punctate appearance, due to the projecting ends of the ribs which are not continuous up the spire; axial sculpture of (on the last whorl 15) strong rounded ribs mostly with somewhat wider interspaces, crossing from suture to suture, but on the base only flexuous incremental lines; spiral sculpture of 2 , or on the last whorl 3 , fine rather feeble threads, widely separated, and fine almost microscopic striae with a single plain thread at the margin of the base, sometimes visible at the suture; aperture obovate; outer lip thin, not reflected, pillar straight, short, attenuated in front, canal very short, wide, not recurved. Height, 6.5; diameter, 2 mm. U. S. Nat. Mus. Cat. No. 108337.

Off Georgia, numerous specimens, mostly worn. Off Fernandina, one young shell.

The typical species is flat-sided and has three spiral rows of subequal beads.

\section{Genus CERITHIELLA Verrill}

Lovenella G. O. Sars, Moll. Reg. Aret. Norv., p. 187, 1878; type Cerithium metula Lovèn.-Verrilu, Amer. Journ. Sci., vol. 20, p. 396, Nov. 1880; Proc. U. S. Nat. Mus., vol. 3 p. 375, 1880. Not of Hincks, 1869.

Cerithiella Verrill, Trans. Conn. Acad. Sci., vol. 5, p. 522, June, 1882; vol. 6. p. $270,1884$.

Newtonia Cossmann, Annuaire Géol., vol. 8, p. 721, 1891; not Newtonia Schlegel, 1866; Aves.

Newtoniella Cossmann, Ann. Soc. Roy. Malac. de Belgique, vol. 28, p. 18, 1893; not Newtoniella Cossmann, Ann. Soc. Roy. de Belgique for 1896, p. 29, 1899; type Cerithium clavus Lamarck.

Cerithiella Iredale, Proc. Malac. Soc. London, vol. 9, p. 260, 1911.

The nucleus of the typical species is like that of Laskeya, the apical whorl is a little inflated, and the arcuate ribbing of the second or nepionic whorl is stronger.

Cerithiella and Newtoniella were based on the original type of Lovenella, hence the action of Cossmann in substituting a new type in 1899, can not be accepted.

Beside the original $C$. metula we know $C$. whiteavesi Verrill, and the following species.

\section{CERITHIella PRODUCta, new species}

Shell slender, acute conic, translucent glossy white, with a somewhat defective but swollen nucleus, and ten subsequent, posteriorly sloping anteriorly rounded whorls; suture distinct, appressed, constricted; periphery of the whorls quite anterior; axial sculpture of (on the last whorl about 25) protractively oblique feeble ribs with narrower interspaces, more distinct on the early whorls and almost obsolete on the last whorl; incrementallines hardly noticeable except on the base; spiral sculpture of a fine line at the suture, a small thread a little in advance of the suture, 2 more prominent threads near the periphery, 
and 2 others, less conspicuous, at the margin of the moderately rounded base; aperture rounded-quadrate, the outer lip thin, slightly protractively oblique; the pillar short and wide, slightly recurved. Height, 8.5; diameter, $2.5 \mathrm{~mm}$. U. S. Nat. Mus. Cat. No. 87305. Off Fernandina, one specimen.

\section{Genus SEILA A. Adams}

SEILA SUBALBIDA, new species

Shell slender, flat-sided, white with pale brownish nebulosities, with 16 subcylindrical whorls exclusive of the (lost) nucleus; suture closely appressed, inconspicuous; axial sculpture only of incremental lines chiefly visible in the interspaces; spiral sculpture of 3 equal strong plain cords on the sides of the whorls, the first close to the suture, the second at the periphery, and the third between it and the succeeding suture; there are 2 feeble threads at the margin of the flattish base; aperture subquadrate, lips thin, the pillar twisted, short, with a prominent edge; canal short, axis minutely pervious. Height, 9; diameter, 2 mm. U. S. Nat. Mus. Cat. No. 108070.

Off Fernandina, three specimens.

\section{Family TRICHOTROPIDAE.}

\section{Genus TRICHOTROPIS Sowerby.}

\section{TRICHOTROPIS (IPHINOPSIS) NUDA, new species}

Shell small, bucciniform, thin, translucent white, with about four roundly shouldered whorls; apex blunt, the suture distinct, not appressed; spiral sculpture of numerous, equally spaced, sharp striae with flattened wider interspaces covering the whole surface; axial sculpture of microscopically fine incremental lines; the last whorl more than three-fourths as long as the whole shell; base somewhat attenuated in front, with a deep narrow umbilicus with a hardly carinated margin; aperture semilunate, the margins thin, the outer lip rounded, the inner lip straight partly overshadowing the umbilicus; there is no indication of a canal. Length of shell, 6 ; of aperture, 3.5; diameter, 3.5mm. U. S. Nat. Mus. Cat. No. 107988.

Off Fernandina, three specimens.

This shell, though small, has the form of Iphinoë and the columella is entirely devoid of plaits. I suspect "Admete" inflata Friele, to belong to the same group. At all events the Iphinoe kelseyi Dall from off San Diego, Calif,, certainly does. The small size, the absence of the hairy periostracum found in Iphinoë, and the deep water habitat of these small shells, indicate the propriety of separating them into a subgenus Iphinopsis ${ }^{5}$ with $I$. kelseyi as type. 
TRICHOTROPIS (IPHINOPSIS) TURRITA, new species

Shell minute, slender, turrited, white, with five or more whorls, exclusive of the (lost) nucleus; suture very distinct, the whorls with a narrow angular shoulder; surface with faint incremental lines; whorls in front of the shoulder flattish; probably in fresh specimens with a fugacious periostracum; base acutely attenuated with a deep narrow umbilicus with a carinate margin; aperture subtriangular, with a narrow projection approaching a canal; margins of the aperture thin, simple, the pillar lip smooth and nearly straight. Length, 3 ; diameter, $1.5 \mathrm{~mm}$.; length of the last whorl, $2 \mathrm{~mm}$. U. S. Nat. Mus. Cat. No. 107986.

Off Fernandina, two specimens.

This species has much the same form in miniature as $T$. borealis Sowerby has on a larger scale.

\section{Family RISSOINIDAE}

\section{Genus RISSOINA Orbigny}

RISSOINA MAYORI, new species

Shell small, white, strongly sculptured, of about 6 moderately convex whorls; suture distinct, not deep; coronated by the blunt ends of the ribs; axial sculpture of (on the last whorl 16) strong rounded vertical ribs with narrower interspaces, crossing the whorls; the ribs are nearly in a continuous series up the spire; spiral sculpture of extremely fine, close, even striation covering the shell; base rounded aperture evenly ovate, the peristome simple, thickened, crossing the body by a bridge of callus. Length, 4 ; diameter, $1.8 \mathrm{~mm}$. U. S. Nat. Mus. Cat. No. 108371.

Off Georgia, one specimen. Also off Miami, Fla., in 58 fathoms; Henderson. Named in honor of the late Dr. A. G. Mayor, of the Tortugas Biological Station.

\section{Family TRUNCATELLIDAE}

\section{Genus TRUNCATELLA Risso}

TRUNCATELLA, species

A broken specimen of this genus was found off Fernandina, doubtless washed in from the shore. U. S. Nat. Mus. Cat. No. 108050.

\section{Family RISSOIDAE}

\section{Genus RISSOA Freminville \\ RISSOA POMPHOLYX, new species}

Shell small, thin, fragile, white, with a glassy nucleus of about one, and nearly three subsequent well rounded whorls; suture distinct, deep; axial sculpture of a few minute wrinkles chiefly on the early $24105-27 \dagger-8$ 
whorls and sometimes absent altogether, and more or less obvious incremental lines; spiral sculpture of extremely faint, almost microscopic striae over most of the surface; last whorl about half as long as the shell, inflated, and much the largest; base rounded; aperture ovate, peristome continuous, thin, sharp, a chink behind the inner lip. Length of shell, 2.5; diameter, $1.7 \mathrm{~mm}$. U. S. Nat. Mus. Cat. No. 108314.

Off Georgia, five specimens.

Some of the specimens have a slightly brownish tint which may be accidental. The species is of a type recalling $R$. coriacea Manzoni, of Madeira.

\section{Section NODULUS Monterosato}

RISSOA (NODULUS) FERNANDINAE, new species

Shell minute, subconic, white, with a blunt apex and about four and a half moderately rounded whorls; suture distinct, not deep; surface smooth, base evenly rounded with a shallow umbilical dimple; aperture rounded, the margin slightly thickened, the peristome not continuous across the body where it is represented by a thin layer of callus. Length, 1.6; diameter, $1.2 \mathrm{~mm}$. U. S. Nat. Mus. Cat. No. 108224.

Off Fernandina, one specimen.

The shell recalls $R$. nitida Brusina, of the Mediterranean. The specimen may be bleached.

\section{Section CINGULINA Monterosato \\ RISSOA (CINGULINA) CURTA, new species}

Shell minute, smooth, turbinate, white, of about three and a half moderately convex whorls; suture distinct, not deep; last whorl much the largest; base rounded, with a deep umbilical dimple; aperture rounded, the peristome thin, sharp, not continuous across the body. Height, 1.2 ; diameter, $1 \mathrm{~mm}$. U. S. Nat. Mus. Cat. No. 333454 .

Off Fernandina, one specimen.

It recalls $R$. triangularis Watson, from Ascension Island in 160 fathoms.

\section{Family CAPULIDAE}

\section{Genus CAPULUS Montfort}

\section{CAPULUS INTORTUS Lamarck}

Capulus intortus Lamarck, An. S. Vert., vol. 6, pt. 2, p. 18, 1822.-Tryon Man., vol. 8, p. 131, pl. 39, figs. 76-6, 1886.

Off Fernandina, one specimen. 


\section{Family NATICIDAE}

\section{EUSPIRA BAHAMENSIS, new species}

Shell small, white, rather depressed, of three and a half well rounded whorls, the suture deep; surface smooth except for two or three spiral striae, directly in front of the suture and more or less obsolete on the later whorls; aperture ovate, narrow behind, outer lip sharp, inner lip nearly straight, not callous, but united by a layer of enamel over the body with the outer lip; umbilicus large, funicular. Altitude, 6.3; diameter, 8 mm. U. S. Nat. Mus. Cat. No. 107447.

Dredged by the United States Bureau of Fisheries at Station 2324, on the Great Bahama Bank in 33 fathoms.

This is nearly the size of $N$. leptalea Watson, but more depressed and with a much larger umbilicus.

\section{Family TURBINIDAE}

\section{Genus LEPTOTHYRA (Carpenter) Pease}

\section{LEPTOTHYRA INDUTA Watson}

Turbo (Collonia) indutus WAtson, Journ. Linn. Soc., vol. 14, p. 715, 1879, Challenger Rep., Gastr., p. 128, pl. 6, fig. 1, 1885.

Leptothyra (induta var.) albida DALL, Bull. Mus. Comp. Zoöl., vol. 9, p. 48, 1881 ; vol. 18 , p. 352 , pl. 38 , fig. $6,1889$.

Leptothyra induta DALL, in Agassiz, Three cruises of the Blake, vol. 2, p. 69, fig. $287,1888$.

Off Georgia and Fernandina, four specimens; thence through the Antilles and Yucatan Strait, in 152 to 640 fathoms.

\section{Family TROCHIDAE}

\section{Genus SOLARIELLA Wood}

SOLARIELlA CANCILLA, new species

Shell minute, conical, white, with a very small smooth nucleus and about five well rounded whorls; suture distinct, not deep; spiral sculpture of (on the penultimate whorl four, on the last whorl six) subequal threads with narrower interspaces evenly spread over the whorl between the sutures; axial sculpture of numerous oblique simjlar threads with narrower interspaces forming above the base with the spirals a dense reticulation; base rounded with similar spirals but the axials obsolete; aperture subcircular; the pillar lip thickened, concavely arcuate, with a minute chink behind it, the remainder of the margin thin, simple, hardly pearlaceous. Height, 3.5; diameter, 3 mm. U. S. Nat. Mus. Cat. No. 108120.

Off Fernandina and Georgia, 46 specimens.

There is some difference in proportions among the specimens, most of which are young, some being more slender than others. 
Shell small, brilliantly polished, white, thin, with a bulbous subspherical smooth nucleus and about four subsequent whorls; suture distinct, the whorl in front of it depressed; axial sculpture of numerous equal and equally spaced plications radiating straightly from the axis but hardiy reaching the periphery; these become more feeble toward the end of the last whorl; the incremental lines are delicate and silky; spiral sculpture of fine equal striation covering the whole surface, more or less strong in different individuals; around the rather wide funicular umbilicus is a strong more or less beaded cord with one or two conspicuous grooves outside of it; walls of the umbilicus finely spirally striated; aperture nearly circular, the margins thin, sharp; internally nacreous. Height of shell, 2.2 ; diameter, 4.2 mm. U. S. Nat. Mus. Cat. No. 87358.

Dredge by the United States Bureau of Fisheries steamer Albatross off Fernandina, Fla., in 294 fathoms sand, at Station 2668, the bottom temperature, $46.3^{\circ} \mathrm{F}$.

This is somewhat like $S$. actinophora but smaller and less elevated, with feebler spirals.

SOLARIELLA AEGLEiS Watson.

Margarita aegleis Watson, Journ. Linn. Soc., vol. 14, p. 704, 1879; Challenger Rep., Gastr., p. 81, pl. 5, fig. 10, 1885.

Solariella aegleis DALL, Bull. Mus. Comp. Zoöl., vol. 18, p. 379, 1889.

Off Fernandina, one specimen.

\section{Genus EUCHELUS Philippi}

\section{EUCHELUS EUCASTA Dall}

Euchelus eucasta Dald, Bull. U. S. Nat. Mus., No. 37, p. 164, 1889.

Shell small, trochiform, snow white, with a minute depressed glassy nucleus of about 1 whorl and 5 subsequent whorls; suture distinct, not deep; whorls only moderately convex, spiral sculpture of (on the penultimate whorl 5, on the base 5) prominent equal and equally distributed threads with subequal interspaces; axial sculpture of (on the last whorl about 40) retractively oblique threads about as strong as the spiral, equal and equally distributed, extending over the whorls and nodulous at the intersections, forming a very regular reticulum; base rounded, imperforate; aperture oblique, rounded, the outer lip simple, with 2 prominent posterior and several feeble lirations internally; pillar lip short with 2 projecting denticles at its anterior part; throat pearly. Height of shell, 6.5 ; of last whorl, 4.5; diameter, $5.3 \mathrm{~mm}$. U. S. Nat. Mus. Cat. No. 93793.

Off Georgia, two specimens.

The extreme regularity of the reticulation is the most striking peculiarity of this species. 


\section{Family VITRINELLIDAE}

\section{Genus Vitrinella C. B. Adams}

VITRINELLA GEORGIANA, new species

Shell minute, glassy white, low turbiniform, with about three and a half smooth, well-rounded whorls; nucleus minute, suture distinct, not deep; aperture subcircular, the peristome interrupted by the body whorl, not reflected, sharp; base roundly convex, with a minute perforate umbilicus, partly shadowed by the inner lip. Height 1.6; diameter, $2 \mathrm{~mm}$. U. S. Nat. Mus. Cat. No. 329375.

Seven specimens of different ages were obtained off Georgia.

\section{Genus BASILISSA Watson}

\section{Subgenus AnCistrobasis Dail}

Ancistrobasis Dalu, Bull. Mus. Comp. Zoöl., vol. 18, p. 383, 1889. Type Basilissa costulata Watson, Dall, Bull. Mus. Comp. Zoöl., vol. 18, pl. 23, figs. 4, 4a., 1889 .

\section{ANCISTROBASIS COSTULATA Watson.}

Basilissa costulata WAtson, Journ. Linn. Soc., vol. 14, p. 600, April, 1870; Challenger Rep., Gastr., p. 103, pl. 7, figs. 11, 11a., 1886.

Off Georgia, four specimens. Yucatan Strait in 640 fathoms; and Sand Key, in 15 fathoms, Blake expedition; off Culebra Island, West Indies, in 390 fathoms, pteropod ooze, Challenger expedition.

Watson's figure is inaccurate in showing the edge of the whorl rounded, while his description says "sharply angulated." The figure in the Bulletin of the Museum of Comparative Zoölogy (vol. 18, pl. 23 , figure $4 a$.), is accurate.

\section{Subgenus BASILISSA s. s.}

BASILISSA WATSONI, new species

Basilissa superba Watson (young), Dall, Mus. Comp. Zoöl., vol. 18, p. 384, 1889.

Shell small (immature?), white, flatly conical, with a glassy minute nucleus of one whorl and seven subsequent whorls; suture closely appressed, not impressed; whorls above the base flat; axial sculpture of many protractively flexuous extremely fine lines with wider interspaces over all the whorls; the cemented edges at the suture by their opacity look like a presutural band, but this is not reflected in the sculpture; spiral sculpture on the spire of almost microscopic close striae; on the base there are about a dozen fine spiral grooves between the edge of the umbilicus and the periphery, a little coarser near the carina; base nearly flat, sharply carinate at the periphery; the umbilicus funicular, deep, the verge carinate; aperture quadrate, slightly oblique, the margin thin, sharp, simple. Height of shell, 4; of last whorl, 2 ; diameter, $5 \mathrm{~mm}$. U. S. Nat. Mus. Cat. No. 94940. 
The locality of this species, dredged by the Albatross off the southeastern coast, was not preserved; it may very probably have been off the coast of Georgia. It was hastily referred to the young of $B$. superba Watson, an Australian shell, but closer study shows its distinctness, as the geographical position rendered probable. The most obvious differences are the simple carinations of the whorl and the margin of the umbilicus, which in the Australian species are beaded. The sculpture of the spire is similar in both.

\section{Family COCCULINIDAE}

\section{Genus CoCCULINA Dall}

COCCULINA LISSOCONA, new species

Shell small, white, conic, with the apex well recurved and slightly behind the middle of the shell; surface smooth, aperture oval, margin entire; interior porcellanous white. Height, 1.5; length, 2.5; width, $1.7 \mathrm{~mm}$. U. S. Nat. Mus. Cat. No. 333472 .

Off Fernandina, 13 specimens. At many localities along the Florida coast and keys, in from 63 to 135 fathoms; J. B. Henderson, jr.

This is the first perfectly smooth species I find among those referred to this genus.

\section{Family SCISSURELLIDAE}

\section{Genus SCISSURELLA Orbigny, 1823}

SCISSURELLA CRISPATA Fleming

Scissurella crispata Fleming, Brit. Animals, p. 366, 1828.-Forbes and Hanley, Brit. Moll., vol. 2, p. 544, pl. 63, fig. 6, 1853.

Off Fernandina, two specimens.

\section{SCISSURELLA PROXima, new species}

Shell minute, white, of nearly four whorls, the slit about onefourth as long as the whorl; the suture distinct, not deep; the posterior surface between the suture and the fasciole arcuately striated; the base moderately convex, the surface nearly smooth, but under the lens showing a faint reticulation of the incremental lines with faint spiral threads; umbilicus perforate; the aperture rounded; the pillar lip slightly reflected. Height, 1.7; diameter, $3 \mathrm{~mm}$. U. S. Nat. Mus. Cat. No. 322962.

Dredged off South Carolina by the United States Bureau of Fisheries Steamer Albatross at Station 2314, in 159 fathoms coarse sand, bottom temperature $47.4^{\circ} \mathrm{F}$.

The species is smaller and relatively more elevated than S. crispata; less elevated and with much less prominent sculpture than $S$. alta Watson, especially on the base. It has been collected in 434 fathoms off St. Augustine, and in numerous other localities on the coast and off the keys of Florida, in 20 to 200 fathoms. 


\section{Family FISSURELLIDAE}

\section{Genus DIADORA Gray}

DIADORA BERMUDENSIS Dall and Bartsch

Fissuridea bermudensis Dall and Bartsch, Proc. U. S. Nat. Mus., vol. 40, No. 1020, p. 286, pl. 35, fig. 8, 1911.

Off Georgia, one dilapidated specimen probably of this species and doubtless derived from shallow water. U. S. Nat. Mus. Cat. No. 108284.

\section{Genus PUNCTURELLA Lowe}

\section{PUNCTURELLA PROFUNDI Jefíreys}

Puñcturella profundi Jeffreys, Proc. Zool. Soc., London, for 1882, p. 675, pl. 50, fig. 10 .

Off Fernandina and Georgia, 19 specimens. Bay of Biscay in 1,003 to 1,450 fathoms, Travailleur expedition. Off Culebra Island, West Indies, in 390 fathoms, Challenger expedition.

The Florida shells appear from the original figure and specimens in the Jeffreys collection to be typical. A variety occurs in which the radial sculpture alternates stronger and weaker and is more or less granulated by incremental lines, which may take the name of multifila.

\section{PUNCTURELLA OXIA Watson}

Puncturella oxia WAtson, Journ. Linn. Soc., vol. 17, p. 36, 1883; Challenger Rep., Gastr., p. 44, pl. 4, fig. 8, 1886.

Shell minute, conical, white, ovate, the anterior slope somewhat convex, the posterior concave, the foramen nearly central, large for the size of the shell, the nuclear whorl not persistent, the internal septum nearly vertical; sculpture of divaricate and obliquely reticulate crowded rows of granules, those on the sides divaricating from the middle line of the side; margin entire, the interior smooth. Length of shell, 3.2 ; breadth, 2.4 ; height, $1.5 \mathrm{~mm}$. U. S. Nat. Mus. Cat. No. 108286.

Off Fernandina and Georgia, two specimens. Off Culebra Island, West Indies, in 390 fathoms, Challenger expedition.

The sculpture is quite remarkable.

\section{PUNCTURELLA HENDERSONI, new species}

Sbell elevated, dingy white with a dextrally incurved apex and a rather long narrow slit extending about one-third of the way to the base; vertical sculpture of about 48 narrow ribs with much wider interspaces and occasional smaller intercalary riblets, the former crenulating the margin; concentric sculpture of uniform fine conspicuous threads with narrower interspaces covering the whole shell and minutely crenulating the vertical sculpture. Height, 9 ; length, 10.2 ; breadth, 8 mm. U. S. Nat. Mus. Cat. No. 333471. 
Off Georgia, one specimen. Off the Sambo reef, Florida Strait in, 120 fathoms; J. B. Henderson, jr.

This elegantly sculptured species is one of the most attractive of the genus.

\section{PUNCTURELLA CIRCULARIS Dall}

Puncturella circularis DaLl, Bull. Mus. Comp. Zoöl., vol. 9, p. 75, 1881; vol. 18, p. 408, pl. 26, figs. 7, 7b., 1889.

Shell small, thin, whitish, conical, the anterior slope nearly straight, the posterior slope and sides more or less concave, the foramen nearly central, the nuclear shell persistent, the internal septum triangular, vertical; concentric sculpture of faint incremental lines; radial sculpture of fine granular threads with much wider flattish interspaces; margin faintly crenulate by the ends of the radials; interior polished. Length of shell, 4.5 ; breadth, 4 ; altitude $3.1 \mathrm{~mm}$. U. S. Nat. Mus. Cat. No. $108152 a$.

Off Fernandina, one specimen. Blake Station 44, in 539 fathoms, northwest of the Dry Tortugas, temperature $39.5^{\circ} \mathrm{F}$. East of Tobago, in 880 fathoms, temperature, $38^{\circ} \mathrm{F}$., United States Bureau of Fisheries.

\section{PUNCTURELLA TENUICULA, new species}

Shell minute, thin, white, the anterior slope nearly straight, the posterior somewhat concave and a little longer; the foramen large for the size of the shell, the internal septum vertical, the nuclear whorl not persistent; sculpture of almost microscopic radial granulations and feeble concentric incremental lines; margin entire, ovate. Length, 3 ; breadth, 2.2; height, $1.6 \mathrm{~mm}$. U. S. Nat. Mus. Cat. No. 108151.

Off Fernandina, one specimen.

This is intermediate in character between Puncturella and Fissurisepta.

Subgenus Cranopsis A. Adams

PUNCTURELLA (CRANOPSIS) ASTURIANA Fischer

Rimula asturiana Fischer, Journ. de Conchyl., vol. 30, p. 51, 1882.-W Atson, Challenger Rept. Gastr., p. 45, pl. 4, fig.4, 1885.-Dall, Bull. Mus. Comp. Zoöl., vol. 18, p. 404, 1889.

Off Fernandina and Georgia, three fine specimens. Gulf of Gascony, Travailleur expedition. Off Cape Florida, in 85 fathoms. Yucatan Strait and eastward to Martinique, in 213 to 640 fathoms.

\section{Genus FISSURISEPTA Seguenza}

\section{FISSURISEPTA TRIANGULATA Dall}

Fissurisepta triangulata DALL, Bull. Mus. Comp. Zoöl., vol. 18, p. 404,1889. Puncturella rostrata WAtson (not Seguenza), Challenger Gastr., p. 48, pl. 4, fig. 10, 1885. 
Shell small, thin, white, elevated, with a small recurved apex, the anterior slope convexly arcuate, the posterior shorter and somewhat concave; the foramen circular, small; the internal septum obliquely set, with no indication of a nuclear whorl; sculpture of more or less divaricate quincuncially arranged conspicious granules on a smooth polished surface; margin entire, ovate, interior polished. Length, 3; breadth, 2.5; height, 4 mm. U. S. Nat. Mus. Cat. No. 108153.

Off Fernandina, eight specimens. Coast of Yucatan, 200 fathoms; United States Bureau of Fisheries. Off Culebra Island, in 390 fathoms, Challenger expedition. Bay of Campeachy, 200 fathoms; Henderson.

The Fernandina specimens are somewhat more slender than those from Yucatan.

\section{Genus EMARGINULA Lamarck}

\section{Subgenus Rimula Defrance}

\section{EMARGINULA (RIMULA) LARVA, new species}

Shell minute, long-ovate, white, with a glassy beadlike nucleus and an enrollment of about one whorl; the apex nearly terminal at the posterior end; anterior slope convexly arched, slit about half as long as the shell, narrower in front, the scar extending backward the whole length of the shell; sculpture of more or less crowded fine granulate radial lines with lines of granules in the interspaces; margin entire, interior polished, the scar of the slit appearing as a rounded ridge; the nucleus is a little prominent on the right side of the spire. Length, 3; breadth, 2.3; height, $1 \mathrm{~mm}$. U. S. Nat. Mus. Cat. No. 108148.

Off Fernandina, 3 specimens.

\section{Subgenus EmarginUla s.s.}

\section{emarginula Cancellata Philippi}

Emarginula cancellata Philippi, Moll. Sicil., vol. 1, p. 114, pl. 5, fig. 15, 1840.-Dall, Bull. Mus. Comp. Zoöl., vol. 18, p. 406, 1889.

Off Fernandina, four broken specimens, apparently of this species. Mediterranean, Philippi. Off Cuba in 127 to 287 fathoms. Off Barbados, in 100 fathoms; Blake expedition.

\section{EMARGINULA COMPRESSA Cantraine}

Emarginula compressa Cantraine, Bull. Acad. Roy. de Bruxelles, vol. 9, p. 2, 1881.-Jefrreys, Proc. Zool. Soc. London, for 1882, p. 679, 1883.DalL, Bull. Mus. Comp. Zoöl., vol. 18, p. 406, 1889.

Off Georgia, two fine specimens of this species. Coast of Portugal and the Mediterranean. Yucatan Strait and eastward to the Lesser Antilles, in 81 to 640 fathoms. 


\section{Family BATHYSCIADIIDAE}

\section{Genus BATHYSCIADIUM Dautzenberg and Fischer ? BATHYSCIADIUM CONCENTRICUM, new species}

Shell minute, yellowish white, conic, circular at the margin, the apex central, the sides slightly convex, sculptured with obvious concentric lines; there is no other sculpture; the margin is simple, the interior polished; height, 1.2; diameter, 2.5 ; length, $2.5 \mathrm{~mm}$. U. S. Nat. Mus. Cat. No. 329353.

Off Georgia, one specimen.

This little shell has the shape and aspect of a Bathysciadium, though there is no radial sculpture and in the absence of the soft parts it is not possible to be certain of the genus.

\section{Family SIPHONARIIDAE}

\section{Genus WILLIAMIA Monterosato}

WILLIAMIA, species

A young specimen of this pelagic Siphonaria was obtained off Georgia, but too immature for specific identification. It lives on floating seaweed and reaches the sea bottom only after death.

\section{Family ISCHNOCHITONIDAE}

\section{Genus ISCHNOCHITON Gray}

\section{ISCHNOCHITON STRIOLATUS Gray}

Chiton striolatus Gray, Spicil. Zoöl., p. 6, 1828.-Reeve, Conch. Icon., Chiton, pl. 22, fig. 144, 1847.

Chiton squamulosus C. B. Adams, Proc. Boston Soc. Nat. Hist., vol. 2, p. 8, 1845.

Ischnochiton striolatus Pilsbry, Tryon, Man. Conch., vol. 14, p. 105, pl. 20, figs. 20-24, 1892.

Off Fernandina, three separated valves (U. S. Nat. Mus. Cat. No. 108159) which appear to belong to this species. St. Thomas, Barbados, and Jamaica, according to Pilsbry. 


\section{SUPPLEMENT}

Part of the material having been mislaid and not recovered until the remainder of the manuscript was in type, it has obliged the writer to bring in this portion as a supplementary item. Circumstances have unfortunately deferred illustration of the new species.

Including these additions the total number of species obtained from the two dredgings, omitting pelagic forms, is 400 . This includes 5 species of Brachiopoda, 41 Pelecypoda, 14 Scaphopoda, and 340 Gastropoda. Of these 93 species were found at both stations, 196 only off Fernandina, and 98 only off Georgia.

Out of the whole number of species collected (400) 240 appear to be new, including the 6 scaphopods described by Mr. J. B. Henderson, jr.

The following species appear in this supplement:

Iphitus tuberatus Jeffreys.

Iphitus reticulatus Dall.

Architectonica bisulcata Orbigny.

Rissoa xanthias Watson.

Rissoa syngenes Verrill.

Rissoa listera Dall.

Rissoa (Cingula) campa Dall.

Rissoa (Cingula) canonica Dall.

Rissoa (Cingula) lampra Dall.

Benthonella nisonis Dall.

Benthonella gaza Dall.

Litiopa bombyx Rang.

Litiopa striata Pfeiffer.

Litiopa basistriata Dall.

Alba conoidea Dall.

Polinices leptalea Watson.

Polinices nana Moller.

Cryptonatica pusilla Say.

Lamellaria fernandinae Dall.

Sinum, species.

Megalomphalus caro Dall.

Vetulonia josephinae Jeffreys

Vetulonia densilirata Dall.

Molleriopsis sincera Dall.

Cocculina reticulata Verrill.

Cocculina georgiana Dall.

Cocculina rotunda Dall.

Basilissa rhyssa Dall.

Ganesa (Lissospira) proxima Tryon.

Ganesa (Lissospira) buseae Dall.

Ganesa (Lissospira) conica Dall.
Ganesa (Lissospira) depressa Dall.

Ganesa (Lissospira) valvata Dall.

Granigyra limata Dall.

Granigyra radiata Dall.

Lydiphnis trilix Bush.

Lydiphnis translucens Dall.

Lydiphnis hendersoni Dall.

Lydiphnis margaritiformis Dall.

Vitrinella carinifex Dall.

Vitrinella massarita Dall.

Vitrinella cerion Dall.

Vitrinella rhyssa Dall.

Pseudorotella solida Dall.

Pseudorotella floridensis Dall.

Calliostoma benedicti Dall.

Calliostoma hendersoni Dall.

Calliostoma tittarium Dall.

Calliostoma halibrectum Dall.

Calliostoma arestum Dall.

Calliostoma trachystum Dall.

Calliostoma kampsa Dall.

Solariella calatha Dall.

Solariella anoxia Dall.

Solariella tubula Dall.

Solariella tubulata Dall.

Solariella tiara Watson.

Micropiliscus constrictus Dall.

Margarites minona Dall.

Dillwynella modesta Dall.

Lippistes planorbis Dall.

Nepionic shell of gastropod. 


\section{Genus IPHITUS Jefireys, 1883}

\section{IPHITUS TUBERATUS Jefireys}

Iphitus tuberatus Jefrreys, Proc. Zool. Sos. London, for 1883, p. 114, pl. 20 , fig. 12 .

Off Georgia and Fernandina, rare and immature.

\section{IPHITUS RETICULATUS, new species}

Shell conic, white, with a brown styliform nucleus of three and one-half subcylindrical whorls and about five subsequent moderately rounded whorls; suture distinct, not deep; spiral sculpture forming with the axial a very regular reticulum, the spirals flat; on the penultimate whorl five, the posterior smaller than the others; on the last whorl six, the anterior forming a carinate border to the base, in front of which on the flattish base are six smaller spirals; axial sculpture of (on the last whorl about 20) retractively oblique equal and equally distributed flattish cords, with obvious incremental lines in the interstices; the base is imperforate, the aperture strongly recalls that of Trichotropis. Height, 5.5; major diameter, $2.7 \mathrm{~mm}$. U. S. Nat. Mus. Cat. No. 108315.

Two specimens off Georgia.

The sculpture of this species is entirely different from that of Jeffreys's type.

\section{Genus ARCHITECTONICA Bolten, 1798}

\section{ARCHITECTONIA BISCULCATA Orbigny}

Solarium bisulcatum Orbignx, Moll. Cuba, vol. 2, p. 66, pl. 19, figs. 17, 20,1845 .

Solarium boreale Verrill and Sмith, Trans. Connecticut Acad. Sci., vol, 5, p. 529, pl. 57, figs. 29, 30, 1882; Proc. U. S. Nat. Mus., vol. 3, p. 376; 1880.

Off Georgia, 19, and off Fernandina, 6 specimens. Also off Cape Cod in 55 fathoms, and off Marthas Vineyard in 115 fathoms, United States Fish Commission, Cubà, Orbigny.

\section{Genus RISSOA Fréminville}

\section{RISSOA XANTHIAS Watson}

Rissoa xanthias WATson, Challenger Gastr., p. 588, pl. 44, fig. 5, 1886.-DALL, Blake Rept., p. 288, pl. 19, fig. 10, 1889.

Off Georgia and Fernandina, numerous. Off Culebra Island, West Indies, in 390 fathoms, and off Pernambuco, Brazil, in 350 fathoms, Challenger expedition.

The graduations between the typical form and the variety acuticostata Dall (1889) are so easy that it is practically impossible to fix a limit. 
RISSOA SYNGENES Verrill

Cingula syngenes Verrili, Trans. Connecticut Acad. Sci., vol. 6, p. 2£0, pl. 32, fig. 11, 1884 .

Off Fernandina, numerous. Off Cape Hatteras, N. C., in 142 fathoms, United States Fish Commission.

RISSOA LiSTERA, new species

Shell small, translucent white, glistening, with three yellowish nuclear whorls and three subsequent, well-rounded whorls; suture distinct, not deep; axial sculpture of more or less obsolete vertical wrinkles stronger on the spire, not passing the periphery of the whorl, and faint incremental lines; spiral sculpture of fine even striae, stronger on the base, covering the whorl; base imperforate, aperture obovate, the margin simple, not connected across the body. Height, $3 \mathrm{~mm}$; diameter, $1.5 \mathrm{~mm}$. U. S. Nat. Mus. Cat. No. 333787.

Off Fernandina, six specimens.

This species groups with $R$. xanthias but is smaller, with translucent shell, feeble sculpture, and without a shoulder to the whorls.

\section{Subgenus Cingula Fleming}

RISSOA (CINGULA) CAMPTA, new species

Shell small, translucent white, slender, with a glassy nucleus of about two whorls and four subsequent well-rounded whorls, separated by a deep suture; axial sculpture of numerous minute close-set vertical riblets, hardly visible without a lens, crossed by microscopic spiral striae over the whole surface; base rounded, imperforate, the lips simple, not meeting over the body. Height, $3.6 \mathrm{~mm}$.; diameter, $1.5 \mathrm{~mm}$. U. S. Nat. Mus. Cat. No. 108403.

Off Georgia, numerous, mostly stained brown by manganese.

RISSOA (CINGULA) CANONICA, new species

Shell small, smooth, opaque, white, with four well-rounded whorls, including a smooth, not differentiated, nucleus and separated by a well-marked but not deep suture; sculpture only of more or less feeble incremental lines; base evenly rounded, imperforate; aperture subovate, not oblique, the margin simple, slightly thickened, not complete in the young but in the adult united by enamel over the body. Height, 2.5; diameter, $1.4 \mathrm{~mm}$. U. S. Nat. Mus. Cat. No. 108094.

Off Fernandina, numerous.

It is possible that perfectly fresh specimens may be less opaque than those here examined. 


\section{RISSOA (CINGULA) LAMPRA, new species}

Shell about the size of $R$. campta but with a more drawn out last whorl and less constricted suture; white, acute, with a small, somewhat irregular glassy nuclear whorl and five subsequent neatly rounded whorls; axial sculpture of numerous fine, thread like nearly vertical riblets crossing the early whorls and reaching near the periphery on the last whorl; they are more or less evident on different specimens; spiral sculpture of five even faint striae, covering the whole surface; base rounded, imperforate; aperture ovate, not oblique, margin simple, thin, united over the body in the adult by a thin layer of enamel. Height, $3.6 \mathrm{~mm}$; diameter, $1.6 \mathrm{~mm}$. U. S. Nat. Mus. Cat. No. 108096.

Off Fernandina, numerous.

\section{Genus BENTHONELLA Dall, 1889}

\section{BENTHONELLA NISONIS Dall}

Benthonella nisonis DaLL, Bull. Mus. Comp. Zoöl., vol. 18, p. 283, 1889.

Off Fernandina, five specimens and fragments. Gulf of Mexico, in 940 fathoms, United States Fish Commission.

\section{BENTHONELLA GAZA Dall}

Benthonella gaza DALL, Bull. Mus. Comp. Zoöl., vol. 18, p. 282, 1889.

Off Fernandina and Georgia, abundant. South to the vicinity of Ceara, Brazil, in 1,019 fathoms, United States Fish Commission.

This is the type of the genus. Jeffreys named the genus Hela, basing it upon another North Atlantic species, but that name was preoccupied.

\section{Genus LITIOPA Rang, 1829}

\section{LITIOPA BOMBYX Rang}

Litiopa bombix RANG, Annales Sci. Nat., p. 303, 1829.-Tryon, Manual Conchology, vol. 9, p. 281, pl. 53, fig. 74, 1887.

Off Fernandina, not rare.

This is of course a pelagic floating species. The specimens agree with Tryon's figure but are only about 4 millimeters long. They are quite smooth under a lens.

\section{LITIOPA STRIATA Pfeiffer}

Litiopa striata Pfenffer, Archiv für Naturg., vol. 1, p. 255, 1840.-Tryon, Manual Conchology, vol. 9, p. 281, pl. 53, fig. 72, 1887.

Off Fernandina, one specimen.

This form is evenly totally spirally striate. 
LITIOPA BASISTRIATA, new species

Shell (originally pale brown?) white or translucent as dredged, brilliantly polished, with a minute brown, reticulate, subcylindrical nucleus of two or three whorls and about four subsequent rather rapidly enlarging whorls; base with 10 or more sharply cut striae with much wider interspaces; aperture rather narrowly ovate, the outer lip thin, the pillar shorter than the aperture with a prominently reflected anterior edge; the body with a thin wash of callus. Height, $5.7 \mathrm{~mm}$; diameter, $2.3 \mathrm{~mm}$. U. S. Nat. Mus. Cat. No. 108406.

Off Georgia, abundant.

The spiral striae rarely reach the periphery.

\section{Genus ALABA A. Adams}

ALABA CONOIDEA Dall

Alaba conoidea Dall, Proc. U. S. Nat. Mus., vol. 12, p. 336, 1889.

Off Georgia and Fernandina, abundant. Also on the Campeche Bank, in 200 fathoms, Dr. W. H. Rush; and off Cape Hatteras, in 63 fathoms.

\section{Genus POLINICES Montfort}

\section{POLINICES NANA Moller}

Natica nana Moller, Kroyer's Natur. Tidsk., vol. 4, p. 80, 1842.

Lunatia nana Verrill, Trans. Conn. Acad. Sci., vol. 5, p. 516, pl. 42, fig. 9, 1882.

A dozen specimens off Fernandina. The species ranges north to Greenland.

\section{POLINICES LEPTALEA Watson}

Natica leptalea Watson, Journ. Linn. Soc. London, vol. 15 (Zoology), p. 261, 1880; Challenger Gastr., p. 441, pl. 27, fig. 7, 1889.

Numerous specimens off Fernandina. Off Sombrero Island in 450 fathoms; Watson.

\section{NATICA (CRYPTONATICA) PUSILla Say}

Natica pusilla SAY, Journ. Acad. Nat. Sci. Phila., vol. 2, p. 257, 1822.-TRYon, Marine Moll. Atlantic Coast, p. 58, fig. 95, 1873.

One fresh specimen was obtained off Georgia.

\section{LAMELLARIA FERNANDINIAE, new species}

Shell very small, naticoid, translucent white, of two and one-half whorls; suture pronounced, not channeled; sculpture of incremental lines, occasionally strongly impressed; aperture large, the pillar retractively arcuate, not reflected; axis imperforate. Height, $3 \mathrm{~mm}$; diameter $3.2 \mathrm{~mm}$. U. S. Nat. Mus. Cat. No. 108110.

One living specimen off Fernandina.

This is much more naticoid in form than L. pellucida Verrill, and much smaller than L. rangi Bergh. 
SINUM, sp. indet.

The apical fragment of a species of Sinum was obtained off Fernandina. The surface is smooth, and it is probably the young of one of the known species. U. S. Nat. Mus. Cat. No. 108110.

\section{Genus MEGALOMPHALUS Brusina, 1871}

Macromphalina Cossmann, 1888; Adeorbis, species Jeffreys, 1885; Fossarus, species Seguenza. 1874; Gyrodisca Dall, 1895.

\section{MEGALOMPHALUS CARO, new species}

Shell minute, whitish, of about two and one-half well-rounded whorls; nucleus minute, glassy; suture deep, not channeled; axial sculpture of rather obvious incremental lines; spiral sculpture of three or more rather sharp grooves near and in front of the periphery; base widely funicular; aperture oblique, wide, the margins thin, simple; a thin film of callus over the body; the periphery of the basal funicle almost carinate, the axis perforate minutely. Height, $1 \mathrm{~mm}$; diameter, $1.2 \mathrm{~mm}$. U. S. Nat. Mus. Cat. No. 108103.

One specimen off Fernandina.

The small size and the spiral grooving distinguish this species from any of the others so far described.

\section{Genus VETULONIA Dall, 1913}

\section{VETULONIA JOSEPHINAE, new name}

Trochus cancellata Jefrreys, Proc. Zool. Soc. London for 1883, p. 96, pl. 20, fig. 4 (not of Roemer, 1835), Josephine Bank.

Off Georgia and Fernandina, rare.

The specimens have been compared with Jeffreys's type.

VETULONIA DENSILIRATA, new species

Shell resembling josephinae but with depressed, almost flat spire, about 35 axial lamellae on the last whorl, the spiral sculpture finer and closer, and the aperture almost circular with continuous margin. Height, $2 \mathrm{~mm}$; diameter, $3 \mathrm{~mm}$. Cat. No. 108116, U. S. N. M.

Two specimens off Fernandina.

\section{Genus MOLLERIOPSIS Bush, 1897}

\section{MOLLERIOPSIS SINCERA Dall}

Adeorbis sincera Dall, Proc. U. S. Nat. Mus., vol. 12, p. 338, pl. 12, fig. 2, 1889.

Molleriopsis sincera Bush, Trans. Conn. Acad. Sci., vol. 10, p. 138, 1897.

Off Georgia and Fernandina, abundant. 


\section{Genus COCCULINA Dall, 1882}

\section{COCCULINA RETICULATA Verrill}

Cocculina reticulata Verrill, Trans. Connecticut Acad. Sci., vol. 6, p. 426, 1885.

One specimen off Fernandina. Off Marthas Vineyard and south to St. Kitts, West Indies, United States Fish Commission.

\section{COCCULINA GEORGIANA, new species}

Shell small, ovate, white, the sculpture like that of $C$. reticulata; the apex at the posterior third, slightly arcuate, the nepionic shell small, subcylindrical, horizontally projecting, smooth; sides nearly parallel, the posterior end a trifle wider; the ends evenly rounded, the margins entire. Length, $3.5 \mathrm{~mm}$; width, $2.5 \mathrm{~mm}$; height, 1.7 mm. U. S. Nat. Mus. Cat. No. 108281.

Off Georgia, 20 specimens.

Like $C$. reticulata in a general way but uniformly smaller and with a different apex.

\section{COCCULINA? ROTUNDA, new species}

Shell small, elevated, conical, white, apex central, erect, blunt; surface with concentric incremental lines and occasional extremeiy faint sparse radiating lines; aperture circular, margin entire. Height, $2.1 \mathrm{~mm}$; d diameter, $3.2 \mathrm{~mm}$. U. S. Nat. Mus. Cat. No. 108156.

Off Fernandina, six, and off Georgia, nine specimens.

The symmetrically rounded cone is so different from the form of most of the other species as to give rise to a suspicion that th may not be a true Cocculina.

\section{Genus BASILISSA Watson, 1879}

\section{BASILISSA (ANCISTROBASIS) RHYSSA, new species}

Shell very small, turbinate, brownish, with six slightly rounded whorls and a minute transparent, glassy nucleus of about one whorl; the whorls acutely carinate; suture distinct, not deep; axial sculpture of small flexuous equal and equally spaced threads ceasing at the carina; base smooth, polished, with a shallow depression in front of the carina; the umbilicus small, deep, funicular, with no keel at the verge; spiral sculpture of one or two prominent keels between the suture and carina, very slightly affected by the axials, and a few faint spiral striae; aperture subquadrate (mature?), the margins thin and flexuous. Height, $2 \mathrm{~mm}$.; diameter, $2.1 \mathrm{~mm}$. U. S. Nat Mus. Cat. No. 108145.

Off Georgia and Fernandina, not rare. Also at station 2 of the Blake, off Cuba, in 220 fathoms.

The brownish color may be adventitious. The small size and compact form are its chief characters, with the rather rough sculpture. 


\section{Genus GANESA Jeffreys, 1883}

Subgenus Lissospira Bush, 1897

\section{LISSOSPIRA PROXIMA Tryon}

Cyclostrema proxima Tryon, Manual Conchology, vol. 10, p. 98, pl. 33, fig. 4, 1888.

Lissospira proxima Bush, Trans. Connecticut Acad. Sci., vol. 10, p. 130, pl. 22, fig. 3, 1897.

Four specimens off Fernandina and 13 off Georgia.

In Miss Bush's article she makes an older genus a subgenus of one of her new genera, which is of course unauthorized by the rules of nomenclature.

\section{LISSOSPIRA BUSHAE, new species}

Shell resembling L. proxima Tryon, but larger, with a less elevated spire, nearly four white well-rounded, smooth, and polished whorls, a well-marked but not deep suture, a perforate umbilicus with no spiral striations around it, a convex base, the aperture nearly circular, the lips united over the body by a thin layer of enamel, margins thin, entire; the inner lip close to but not reflected over the umbilicus. Height, $3.3 \mathrm{~mm}$.; diameter, $2.7 \mathrm{~mm}$. U. S. Nat. Mus. Cat. No. 108139.

Two specimens off Fernandina.

\section{LISSOSPIRA CONICA, new species}

Shell small, white, smooth, polished, conic, with a little more than four whorls, moderately rounded, the immature specimens having an angle at the margin of the base on which the suture is laid, but this disappears on the last adult whorl; suture distinct, not deep; base rounded, the aperture rounded, the lips united over the body by a thin wash of enamel; the inner lip in the adult reflected over and nearly closing the small perforate umbilicus, which is not surrounded by any spiral sculpture. Height, $2 \mathrm{~mm}$; diameter, $1.7 \mathrm{~mm}$. U. S. Nat. Mus. Cat. No. 108107.

Three specimens off Fernandina.

The relatively narrow conical form is not shared by any of the species described from the coast.

\section{LISSOSPIRA DEPRESSA, new species}

Shell small, depressed turbinate, white, smooth, with about three whorls, the last much the largest; whorls well rounded, suture distinct, not deep; base rounded, aperture somewhat oblique, angulated above and below, the lips simple, thin, not reflected, united by a layer of enamel over the body; umbilicus perforate, the verge marked by a distinct angle, not surrounded by any spiral sculpture. Height, 1.5 mm.; diameter, $2 \mathrm{~mm}$. U. S. Nat. Mus. Cat. No. 108131.

Fifteen specimens off Fernandina. 


\section{LISSOSPIRA VALVATA, new species}

Shell small, white, smooth, polished, with about four well-rounded whorls, separated by a distinct but not deep suture; spire only moderately elevated, the nucleus small, glassy; base rounded, smooth, with a small perforate umbilicus; aperture circular, slightly oblique, the margins simple, thin, except that the inner lip near the umbilicus is slightly reflected and thickened; some of the immature specimens show a slight angulation around the umbilical depression. Height, $2 \mathrm{~mm}$.; diameter, $2.6 \mathrm{~mm}$. U. S. Nat. Mus. Cat. No. 108129.

Off Fernandina and Georgia, abundant.

This resembles $L$. depressa but is larger, the whorls more regularly enlarging and one more in number.

The small shells which have been included in Cyclostrema, Adeorbis, Vitrinella, and so on by authors, undoubtedly belong to a considerable variety of groups. Their proper reference in classification must be tentative until their anatomy and other characters than those of the shells are definitely known.

\section{Genus GRANIGYRA Dall, 1889}

GRANIGYRA LIMATA Dall

Cyclostrema (Granigyra) limatum Dall, Bull. Mus. Comp. Zoöl., vol. 18, p. 395, 1889; Bull. 39, U. S. Nat. Mus., p. 166, 1889.

Granigyra limata Bush, Trans. Connecticut Acad. Sci., vol. 10, pp. 115, 135. 1897.

Off Georgia and Fernandina, not rare. Blake station 19, in 310 fathoms, Gulf of Mexico. United States Fish Commission station 2150, near Old Providence Island, in 382 fathoms, ooze, bottom temperature $46^{\circ} \mathrm{F}$.

GRANIGYRA RADIATA, new species

Shell resembling $G$. Limata but more closely coiled, the granulation less coarse, with three and one-half whorls, the last whorl much the largest; the suture distinct, not deep, with a fringe-like series of short radiating grooves not reaching the periphery; base rounded with a perforate umbilicus around which fine wrinkles appear on the verge; aperture obovate, somewhat angulated above, the margins thin, simple, not reflected. Height, $2.5 \mathrm{~mm}$.; diameter, $2.3 \mathrm{~mm}$. U. S. Nat. Mus. Cat. No. 108138.

Three specimens off Fernandina.

The radiating sculpture sufficiently distinguishes the species.

Genus LYDIPHNIS Melvill, 1906=CIRCULUS Busch, 1897, not Jeffreys 1865

LYDIPHNIS MARGARITIFORMIS, new species

Shell small, white, with nearly four whorls including a minute globular nucleus, having a general form much resembling Margarites helicinus; whorls moderately rounded, the last much the largest, 
suture distinct, not deep; surface smooth except for faint incremental lines, and on the base two strong widely spaced threads around the umbilical pit and a few faint spiral striae behind them; base rounded, umbilicus minutely perforate; aperture rounded with a small angulation above, the peristome continuous over the body, thin, and not reflected. Height, $3 \mathrm{~mm}$.; diameter, $4 \mathrm{~mm}$. U. S. Nat. Mus. Cat. No. 108146.

Two specimens off Fernandina.

This differs from typical Lydiphnis in being less depressed and without carinae, but seems most nearly allied to that genus.

LYDIPHNIS TRILIX Bush

Skenea trilix Bush, Comm. Fisheries Rept. for 1883, p. 584, 1885.

Circulus trilix Bush, Trans. Conn. Acad. Sci., vol. 10, p 127, pl. 22, figs. 6, $10,10 a, 12 a-g$; pl. 23 , figs. $10,15,1899$.

Off Fernandina, 25 specimens.

\section{LYDIPHNIS TRANSLUCENS, new species}

Shell minute, translucent white, the spire flattened, with three moderately rounded whorls; axial sculpture of incremental lines only; spiral sculpture of a thread slightly in front of the suture and another beyond the periphery on the base; these are hardly prominent enough to be called carinae; the umbilical pit is wide and shallow, the umbilicus itself minutely perforate; aperture rather wide, rounded, oblique, the margin thin, continuous, straight near the umbilicus. Height, $1.5 \mathrm{~mm}$; diameter, $2 \mathrm{~mm}$. U. S. Nat. Mus. Cat. No. 108434 ,

Off Georgia, two specimens.

Notwithstanding its small size it has the shell characters of the genus. The incremental lines are rather pronounced.

LYDIPHNIS HENDERSONI, new species

Shell small, white, depressed, glassy, with about three tricarinate whorls, the nucleus deeply sunken; axial sculpture of faint incremental lines, on the spire retractively oblique and on the base protractively arcuate; spiral sculpture of a prominent carina at the periphery, a less prominent one on the spire about one-third of the way from the suture to the periphery, and on the base another slightly nearer the umbilicus than to the periphery; these two secondary keels are variable, sometimes strong, sometimes almost obsolete, sometimes partly one or the other on the same specimen; the edges of the carina are sometimes finely spirally striated, suggesting that they may when fresh and intact carry a series of epidermal fringes like Episcynia; the space within the basal carina is funicular, extending to a moderately narrow perforate umbilicus; the aperture would be rounded, but in those specimens in which the 
carinae are all developed the thin margin is modified and the aperture is angulated by them; in some specimens faint spiral striation is indicated on the surface between the carinae; the margin of the aperture in the adult is continuous over the body of the shell. Maximum diameter, $3.5 \mathrm{~mm}$; minimum diameter, $2.9 \mathrm{~mm}$; height, $1.3 \mathrm{~mm}$. U. S. Nat. Mus. Cat. No. 108396.

Numerous off Georgia.

The periostracum on Episcynia is extremely fugacious, and it is not prudent to assume that these and other small shells dredged and showing none are normally without one. A few have a persistent periostracum, and there is no good reason to suppose that others never possess one. This interesting species is named in honor of the late J. B. Henderson, jr.

\section{Genus VITRINELLA C. B. Adams, 1850}

VITRINELLA MASSARITA, new species

Shell small, smooth, white, trochiform with three and one-half whorls, the nucleus globular; suture deep, the inflated whorls giving a somewhat turrited appearance to the shell; base amply rounded, the umbilicus minutely perforate, the whorl evenly rounded into it; aperture circular, the margins thin, sharp, united over the body; the only sculpture very faint incremental lines. Height, $1.5 \mathrm{~mm}$.; diameter, $1.7 \mathrm{~mm}$. U. S. Nat. Mus. Cat. No. 108137.

Three specimens, off Fernandina.

\section{VITRINELLA CERION, new species}

Shell small, white, smooth, polished, with about four whorls including a minute globular nucleus; whorls well rounded, separated by a distinct not deep suture in front of which is a narrow, flattish area; sculpture only of a few faint spirals on the earlier part of the spire; base well rounded with a small perforate umbilicus; aperture nearly circular, the margins united over the body by a thin layer of enamel. Height, 1.5; diameter, $1.8 \mathrm{~mm}$. U. S. Nat. Mus. Cat. No. 108433.

One specimen, off Georgia.

The general form recalls that of Helix chersina Say.

\section{VITRINELLA RHYSSA, new species}

Shell small, depressed, white, with about two and one-half rapidly enlarging whorls following a small glassy globular nucleus; suture distinct, not deep; sculpture of close even prominent incremental lines over the whole shell; base rounded, umbilical pit excavated; aperture oblique, the margins separated by the body, slightly angular at their junction; from the lower angle a thread decends into the umbilicus. Height, $1.3 \mathrm{~mm}$; diameter, $2.1 \mathrm{~mm}$. U. S. Nat. Mus. Cat. No. $108127 b$.

One specimen, off Ferandina. 
VITRINELLA? CARINIFEX, new species

Shell small, translucent white, the spire depressed, with three whorls, the last whorl much the largest; suture distinct, not deep; the last whorl with the periphery at the posterior third, giving an effect which calls to mind the rounded variety of the fresh-water Carinifex; sculpture only of feeble incremental lines; base with the slope toward the small umbilicus slightly flattened; the verge of the umbilicus almost carinate; aperture obovate, the lips thin, united over the body by a marked layer of enamel. Height, $2.5 \mathrm{~mm}$; diameter, $3.7 \mathrm{~mm}$. U. S. Nat. Mus. Cat. No. 108399.

Off Georgia, three specimens.

This is probably not a true Vitrinella and may be immature but certainly is not the young of any of the species enumerated in this discussion.

\section{Genus PSEUDOROTELLA Fischer, 1857}

PSEUDOROTELLA SOLIDA (DaII)

Ethalia solida DALL, Bull. Mus. Comp. Zoöl., vol. 18, pt. 2, p. 362, pl. 28, figs. $3,5,1889$.

Off Georgia and Fernandina, numerous. Also off Bahia Honda, Cuba, in 310 fathoms, bottom temperature $62^{\circ} \mathrm{F}$., Blake expedition.

\section{PSEUDOROTELLA FLORIDENSIS, new species}

Shell small, porcellanous white, smooth, polished, turbinate, with four well-rounded whorls; suture distinct, not deep; aperture nearly circular, the margin simple, continuous over the body with a marked deposit of enamel behind the body lip and over the umbilical region, completely closing the umbilicus and in the completely adult sometimes produced in subangulate form above and below. Height, 2 mm.; maximum diameter, 3 mm. U. S. Nat. Mus. Cat. No. 108133.

Off Fernandina, abundant.

This is much like $P$. solida, but larger, more elevated, and with the umbilical pad heavier and more simple.

\section{Genus CALLiOSTOMA Swainson, 1840}

CALLIOSTOMA BENEDICTI Dall

Calliostoma (Eutrochus) benedicti DaLL, Bull. Mus. Comp. Zoöl., vol. 18, p. 371, pl. 32, fig. 7, 1889.

Two very young specimens off Fernandina. Off Cape Lookout, N. C., in 200 fathoms. United States Fish Commission.

The Trochidae in this collection are chiefly represented by immature and sometimes very small specimens.

\section{CALLIOSTOMA (EUTROCHUS) HENDERSO NI DaII}

Calliostoma hendersoni Dall, Proc. U. S. Nat. Mus., vol. 70, No. 2668, p.7, Feb. 1927.

Off Fernandina, one very young specimen, and off the Sambo Reef, Fla., in 116 fathoms. Henderson. 
CALLIOSTOMA (EUTROCHUS?) TITTARIUM, new species

Shell small, bluntly conical, white, with about five whorls and a small subglobular nucleus; surface polished, the whorls flattened, the last whorl subcarinate, the base slightly convex, with a minutely perforate umbilicus partly obscured by a reflection of the pillar lip; spiral sculpture variable; usually there is a sharp groove just behind the rather obscure suture, the rest of the of whorl behind this groove smooth; other specimens have several grooves on this part of the shell and others on the base; there are always one or two strong cords around the umbilicus; there is no visible axial sculpture; aperture subquadrate, the pillar lip straight, simple, thickened near its insertion. Height, $3.5 \mathrm{~mm}$; major diameter, $2.5 \mathrm{~mm}$. U. S. Nat. Mus. Cat. No. 108417.

Off Georgia, three, and off Fernandina, six specimens, mostly in poor condition.

CALLIOSTOMA HALIBRECTUM, new species

Shell small, depressed, turbinate, whitish, with about five moderately convex whorls, more or less constricted in the sutural region, and a very minute, mostly immersed, smooth nucleus; base flattish and apparently smooth within the rounded peripheral carina; spiral sculpture of (on the last whorl about a dozen) subequal flattish threads between the carina and the preceding suture; these are cut very obliquely by sharp retractive grooves, producing a rather uniform series of small diamond-shaped, flattish sections of the threads; base imperforate, aperture defective but apparently subquadrate, with a thick pillar. Height of specimen, $6 \mathrm{~mm}$.; major diameter, $9 \mathrm{~mm}$. U. S. Nat. Mus. Cat. No. 108126.

One specimen off Fernandina, in poor but recognizable condition.

CALLIOSTOMA ARESTUM, new species

Shell small, brownish or whitish, with four and one-half whorls following a polished white nucleus of somewhat less than one whorl; form subconic with very prominent sculpture; spiral sculpture on second whorl two, on the third whorl three, on the last whorl above the base four, and on the base six spirals, of which two near the periphery are stronger, the one in front smaller but conspicuously beaded, those on the imperforate base similar, smaller, with subequal interspaces, two or three near the axis more prominently beaded; all the spirals show more or less obscure tendency to beading; there is also a fine simple undulated thread between the first two spirals on the last whorl; axial sculpture only of retractively oblique incremental lines; aperture rounded except as modified by the sculpture, the pillar straight with a conspicuous notch at the anterior end. Height of shell, $5 \mathrm{~mm}$.; of last whorl, $3 \mathrm{~mm}$.; major diameter, $5 \mathrm{~mm}$. U. S. Nat. Mus. Cat. No. 108412. 
Off Georgia, 14 specimens and fragments.

The species recalls $C$. circumcinctum Dall, but the minor sculpture is quite different.

\section{CALLIOSTOMA TRACHYSTUM, new species}

Shell minute, whitish subturbinate, with a little more than three well-rounded whorls, with a minute glossy globular nucleus; spiral sculpture of (on the last whorl above the base, five) subequal prominent threads, and on the base about five flattish, rather obscure threads; the spirals are not evident on the earlier whorls; axial sculpture on the spire of fine obliquely retractive threads with wider interspaces; as these appear on the last whorl and intersect the spirals above the base, minute sharp pustulation is produced, but not on the base which is rounded and very minutely perforate; aperture rounded with a small callus on the pillar. Height, $2 \mathrm{~mm}$.; major diameter, $2.5 \mathrm{~mm}$. U. S. Nat. Mus. Cat. No. 108419.

One specimen off Georgia.

This may be not quite adult, and possibly referable to Solariella.

CALLIOSTOMA (EUTROCHUS?) KAMPSA, new species

Shell small, white, turbinate, of about five well-rounded whorls with a very minute glassy nucleus of about one whorl; suture distinct, not deep; the first three whorls are almost smooth, the fourth shows three, the last five prominent equally distributed spiral cords above the base, two smaller beaded threads between the preceding suture and the first cord, and about a dozen simple spirals on the base; axial sculpture on the last pair of whorls of obliquely retractive sharp threads which are chiefly conspicuous in the interspaces and do not nodulate the spiral cords; these are feeble on the base except near the verge of the umbilical pit where they nodulate minutely the two nearest spirals; the base is evenly rounded, the umbilicus deep and narrow; the aperture is rounded, simple, with a thin straight pillar, the lips not united across the body; height of shell, 5 ; of last whorl, 3; major diameter, 5 mm. U. S. Nat. Mus. Cat. No. 108423.

One specimen and two fragments off Georgia.

This is another species on the border line between Eutrochus and Solariella, conchologically.

\section{Genus SOLARIELLA Wood}

SOLARIELlA CALATHA, new species

Shell small, somewhat depressed, whitish, with a small globular protoconch and about one smooth nuclear whorl, followed by four or more sharply sculptured whorls; suture obscure, in a deep channel formed by the prominent spiral in front of it; the second and third whorls show a single threadlike spiral between the presutural ridge and the succeeding suture; the last whorl has two prominent cords, 
one on each side of the periphery, and three less prominent on the base, the inner one forming the margin of the funicular umbilicus; axial sculpture of sharp radiating lamellae, nodulose on the presutural ridge, with much wider interspaces, only slightly enlarged where they cross the spiral cords, beading the verge of the deep umbilicus into which they prominently descend; base rounded under the sculpture, aperture rounded except for the modification by the spiral sculpture, thin sharp-edged, somewhat oblique. Height of shell, 4; of last whorl, 3 ; major diameter, $5 \mathrm{~mm}$. U. S. Nat. Mus. Cat. No. 108424.

Thirteen specimens and fragments off Georgia, and 19 young shells off Fernandina. A fragment has a major diameter of 6 millimeters, but the description is based on a younger and more perfect specimen.

SOLARIELLA ANOXIA, new species

Shell small, white, with about five whorls following an obliquely tilted glassy subglobular nucleus; the cone of the shell is acute, except that the last whorl suddenly disproportionately enlarges; suture distinct, a small flattening in front of it gives a slight effect of tabulation to the whorls; spiral sculpture of (on the spire two, on the last whorl above the base, five) rather angular ridges, on the last whorl one near the suture, and four a little nearer the periphery, alternating in prominence, with subequal interspaces, and on the rounded base with much wider interspaces; there is no sharp edge to the moderate-sized funicular umbilicus; axial sculpture of numerous low equal and equally spaced vertical lamellae which extend over the whole surface minutely nodulating the intersections with the spiral sculpture, forming a neat reticulation; aperture rounded, the lips thin, united over the body by a thin wash of enamel. A variety occurs with the spirals feeble or partly obsolete. Height of shell, 3; of last whorl, 1.7; major diameter, $2.5 \mathrm{~mm}$. U. S. Nat. Mus. Cat. No. of type, 108142; of the variety, 108420 .

Ten specimens, mostly young, off Fernandina, nine off Georgia.

SOLA RIELla TUBULA, new species

Shell small, white, depressed conical, with four well-rounded whorls following a glassy subglobular nucleus; suture distinct, not deep; spiral sculpture of a few feeble striations in front of the suture, the periphery mostly smooth, and two or three threads around the verge of the wide funicular umbilicus; axial sculpture, most distinct on the younger whorls, of numerous equal and equally spaced radiating wrinkles, most prominent on the shoulder of the whorl, barely reaching the periphery, and frequently obsolete on the last whorl; there is sometimes a low ridge near and in front of the suture, giving an excavated look to the depression between them, and in crossing this ridge the wrinkles become feebly nodulous at the intersections. Height of shell, 3 ; major diameter, 5 mm. U. S. Nat. Mus. Cat. No. 108140. 
Abundant off Fernandina, fewer off Georgia. The aperture is simple and rounded, the lips thin and sharp, with a thin wash of enamel uniting them over the body.

\section{SOLARIELLA TUBULATA new species}

Shell small, white, conic, with a glassy nucleus of about one whorl, and four subsequent tabulate normal whorls; suture distinct, not channeled; the first whorl smooth, the second and third with two prominent spiral threads, one on each side of the periphery, and three on the last whorl, with a fine thread sometimes between them, with several on the moderately convex base; axial sculpture of well-marked oblique incremental lines and on the periphery between the major spirals, connecting threads with wider interspaces nodulating the intersections with the threads; aperture oblique, rounded except as modified by the sculpture, the lips thin, the pillar lip straight, with a small perforate umbilicus behind it. Height, 3.5 ; major diameter, $3 \mathrm{~mm}$. U. S. Nat. Mus. Cat. No. 108109.

One specimen (the type) and a fragment off Fernandina, and six off Georgia, mostly defective.

\section{SOLA RIELLA TIARA Watson}

Trochus (Zizyphinus) tiara W ATson, Linn. Soc. Journ., vol. 14, p. 696, 1879; Challenger Gastropods, p. 60, pl. 6, fig. 4, 1885.

Calliostoma tiara Dall, Bull. Mus. Comp. Zoöl., vol. 9, p. 45, 1881.

One specimen, rather dilapidated, from off Fernandina, may probably belong to this species. St. Thomas and Bermuda, Challenger expedition.

\section{New section MICROPILISCUS Dall}

Shell like Solariella but with a brown nucleus of several whorls and depressed turbinate form.

Type.-Solariella constricta Dall.

The normal nucleus of Solariella is small, white, with usually a subglobular glassy protoconch more or less immersed in the spire.

SOLARIELLA (MICROPILISCUS) CONSTRICTA, new species

Shell minute, greasy white, with a brown (horny?) nucleus of two whorls and depressed turbinate form and three subsequent well-rounded whorls; suture distinct, deeply constricted; spiral sculpture of fine almost microscopic striae over the whole surface; axial sculpture of very oblique fine incremental lines; base rounded, more strongly striated, with a very minute perforate umbilicus, aperture rounded, the lips thin, united over the body by a deposit of enamel. Height, 3.5; major diameter, $3.1 \mathrm{~mm}$. U. S. Nat. Mus. Cat. No. 108414.

Seven specimens off Georgia. 


\section{Genus MARGARITES Leach}

MARGARITES (LIRULARIA) MIONA, new species

Shell minute, white, trochiform, with a minute smooth nucleus and about three and one-half subsequent whorls; the nucleus is somewhat obliquely set; whorls well rounded, the suture distinct; spiral sculpture variably strong or feeble, with usually three or four threads in the vicinity of the periphery, feebler ones on the base, with one or two stronger around the umbilicus; axial sculpture of numerous radial wrinkles extending from the suture to the first spiral thread, then obsolete, except in strongly sculptured specimens on which the axial sculpture reappears on the base, especially near the umbilicus, and rarely shows as beading on the stronger spirals; umbilicus moderate, without an angular verge; aperture rounded, lips thin, united by enamel over the body. Height, 2 ; major diameter, $1.6 \mathrm{~mm}$. U.S. Nat. Mus. Cat. No. 108143.

Twenty-five specimens off Fernandina and three off Georgia.

\section{Genus DILLWYNELLA Dall}

\section{DILLW Y NELLA MODESTA DalI}

Dillwynella modesta DALL, Bull. Mus. Comp. Zoöl., vol. 18, p. 362, pl. 21, figs. $3,3 a, 1889$.

One specimen off Fernandina and five off Georgia, mostly immature. Off Santa Lucia in 226 fathoms, bottom temperature $51^{\circ} \mathrm{F}$.

\section{Genus LIPPISTES Montfort}

LIPPISTES? PLANORBIS, new species

Shell minute, white, evenly enrolled, the whorls adjacent, about two and one-half in number; spiral sculpture none; axial sculpture of fine, close, even threadlike vertical wrinkles surrounding the whorl, feebler on the periphery; aperture circular, entire. Height, 0.7; major diameter, $1.2 \mathrm{~mm}$. U. S. Nat. Mus. Cat. No. 108091.

One specimen off Fernandina.

The shell may not be mature. The enrollment is remarkably planate. 


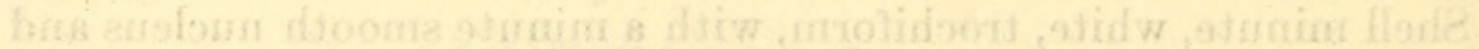

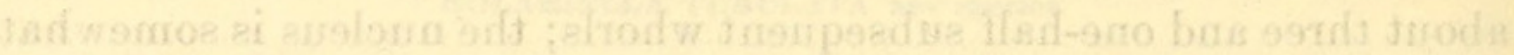

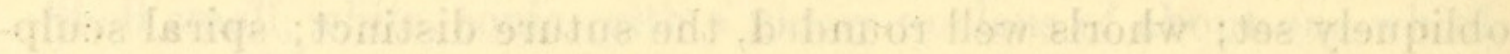

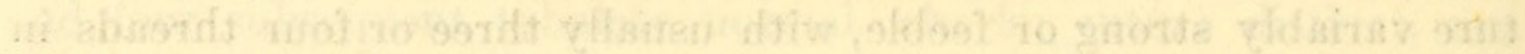

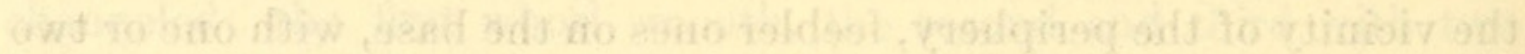

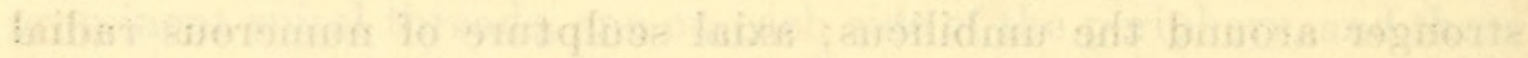

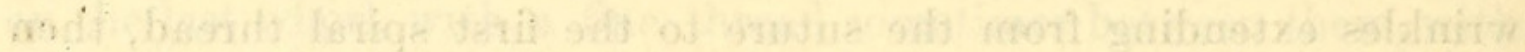

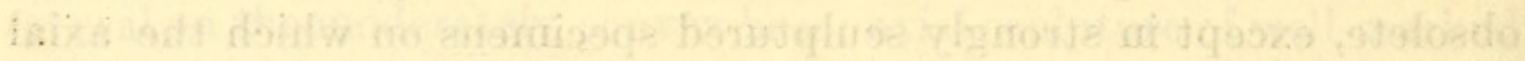

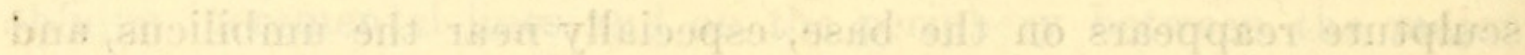

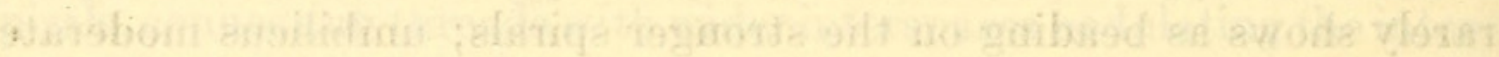

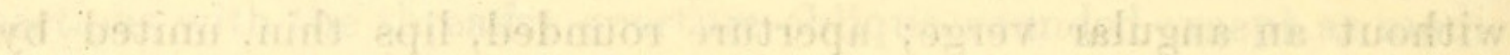

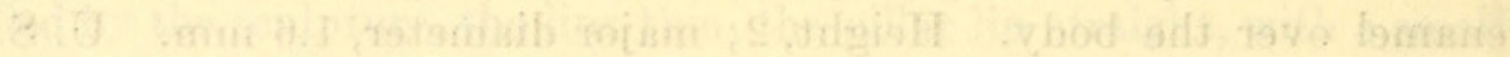

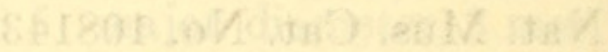

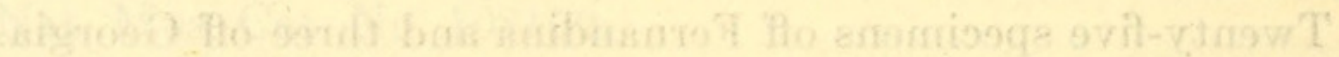

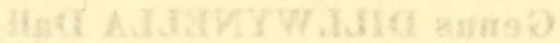

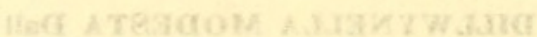

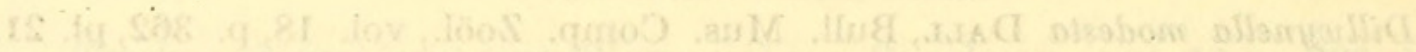
$0281,08,8,89$ ?

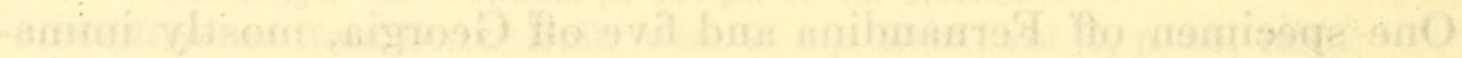

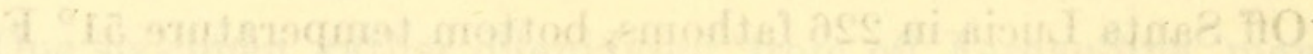

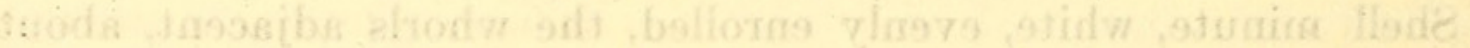

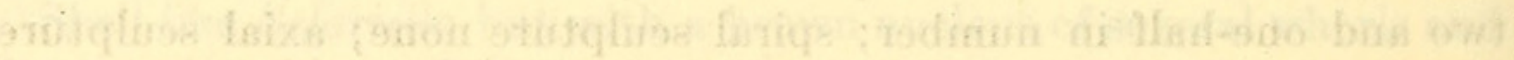

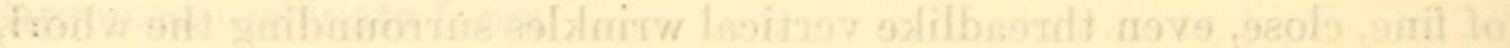

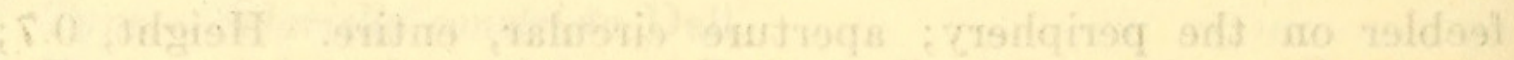

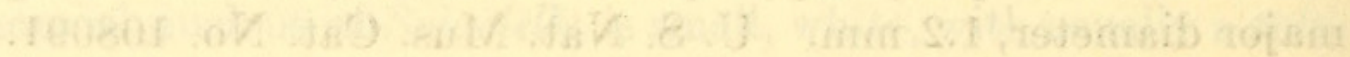

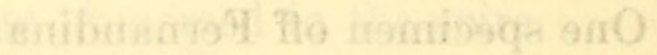

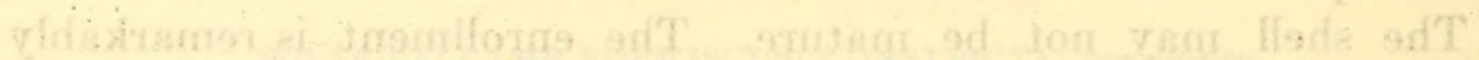




\section{INDEX TO GENERA}

\begin{tabular}{|c|c|}
\hline r & ( \\
\hline 68 & Epitonium \\
\hline 19 & Ervilia . \\
\hline 42 & \\
\hline 119 & ( \\
\hline 87 & lus .......... \\
\hline -.... & ra ........... \\
\hline$\ldots .10$ & \\
\hline 16 & $8:$ \\
\hline$\cdots$ & ria \\
\hline ....... & pta \\
\hline 16 & \\
\hline ....- & .... \\
\hline .... & (n.............. \\
\hline (n)............ & (3-1) \\
\hline (n)................ & ra \\
\hline n........... & 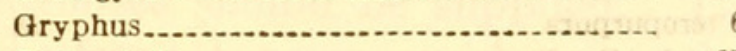 \\
\hline . & la \\
\hline ca & pha . ........... \\
\hline (1) & (2) \\
\hline n. & is .. \\
\hline (n).............. & - nen. \\
\hline - & on \\
\hline (n) & \\
\hline$\ldots$ & B n....... \\
\hline na........ & (n............ \\
\hline (n) & - \\
\hline (n)............... & \\
\hline n.......... & a \\
\hline (n)............... & sems \\
\hline (n) & ... \\
\hline (n.......... & $\ldots$. \\
\hline illia _._. & (n................ \\
\hline (110, 121 & (n) \\
\hline (n) & (n) \\
\hline 1...... & (n) \\
\hline 11 & ....... \\
\hline .......... & Is ..... \\
\hline (n) & 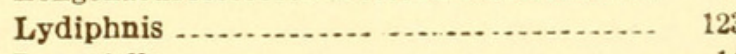 \\
\hline (n) & (1 - \\
\hline 2 & (1) \\
\hline 然 & $29,31,32,3$ \\
\hline (n) & s n........................ \\
\hline a & and \\
\hline (n) & ... \\
\hline 27,36 & halus ............ \\
\hline 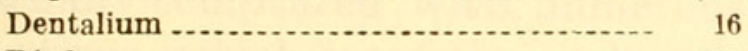 & (2) \\
\hline (n) & illa \\
\hline (n) & cus \\
\hline ........... & (n) \\
\hline a. & 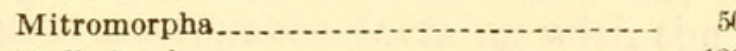 \\
\hline (n) & sis \\
\hline 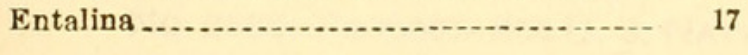 & (n) \\
\hline
\end{tabular}




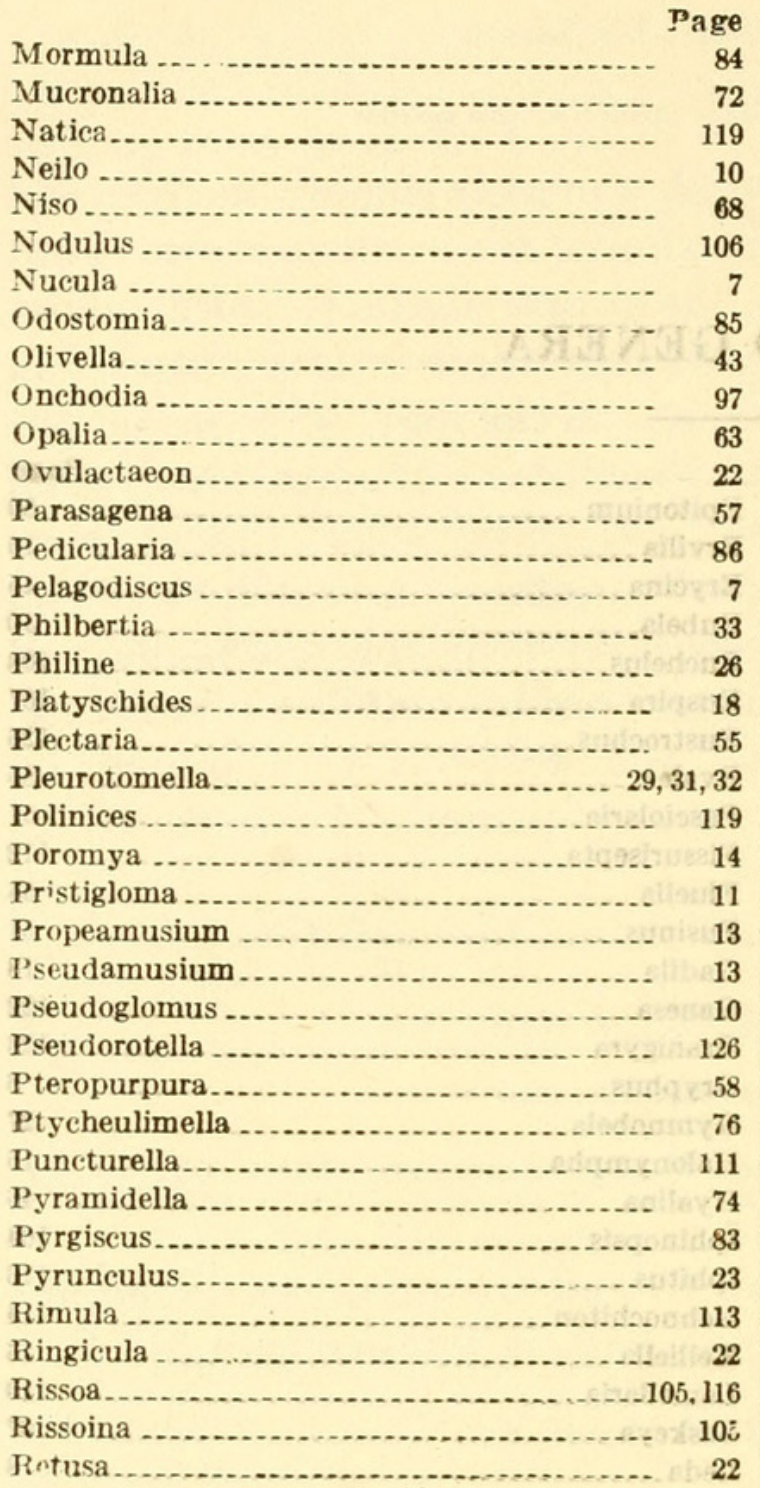

Page

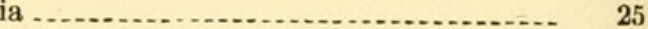

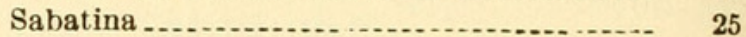

Scaphander ............................... 26

Scissurella _................................. 110

Seguenzia.................................. 86

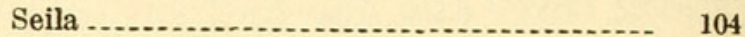

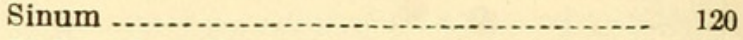

Siphonodentalium .......................... 17

Siphonorbis.................................. 52

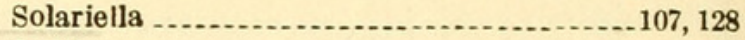

Stilifer ....................................... 73

Stilus..................................... 102

Strioturbonilla_......................... 77

Strobiligera ............................... 94

Strombiformis ............................ 68

Suavodrillia ............................. 35

Sulcorinella ............................

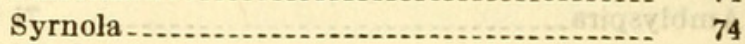

Terebratulina ........................... 6

Thais ........................................ 60

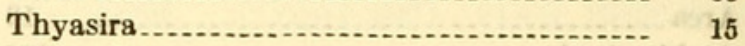

Tindaria ...... 10

Trichotropis ................................. 104

Trigonulina.................................. 14

Triphora

Truncatella ................................... 105

Tuba ....................................... 91

Turbonilla _............................ 76

Turridrupa ............................ 31

Turritellopsis. ............................ 92

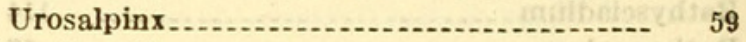

Verticordia .................................. 14

Vetulonia. ............................. 120

Vitrinella_................................ 109, 125

Volvulella ................................ 22

Williamia ...................................... 114

Yoldiella_.......... 

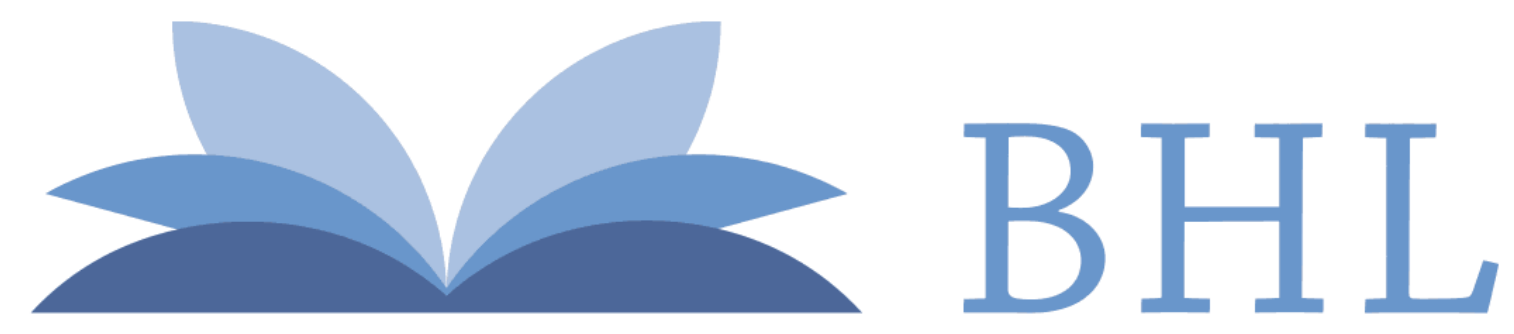

\section{Biodiversity Heritage Library}

Dall, William Healey. 1927. "Small shells from dredgings off the southeast coast of the United States by the United States Fisheries steamer Albatross in 1885 and 1886." Proceedings of the United States National Museum 70(2667), 1-134. https://doi.org/10.5479/si.00963801.70-2667.1.

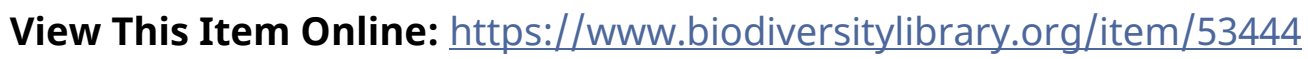

DOI: $\underline{\text { https://doi.org/10.5479/si.00963801.70-2667.1 }}$

Permalink: https://www.biodiversitylibrary.org/partpdf/52015

\section{Holding Institution}

Smithsonian Libraries

\section{Sponsored by}

Smithsonian

\section{Copyright \& Reuse}

Copyright Status: Public domain. The BHL considers that this work is no longer under copyright protection.

This document was created from content at the Biodiversity Heritage Library, the world's largest open access digital library for biodiversity literature and archives. Visit BHL at https://www.biodiversitylibrary.org. 